\title{
Revised Nomenclature for Avian Telencephalon and Some Related Brainstem Nuclei
}

\author{
ANTON REINER, ${ }^{1 *}$ DAVID J. PERKEL, ${ }^{2}$ LAURA L. BRUCE, ${ }^{3}$ ANN B. BUTLER, ${ }^{4}$ \\ ANDRÁs CSILLAG,${ }^{5}$ WAYNE KUENZEL, ${ }^{6}$ LORETA MEDINA, ${ }^{7}$ GEORGE PAXINOS, ${ }^{8}$ \\ TORU SHIMIZU, ${ }^{9}$ GEORG STRIEDTER, ${ }^{10}$ MARTIN WILD, ${ }^{11}$ GREGORY F. BALL, ${ }^{12}$ \\ SARAH DURAND,${ }^{13}$ ONUR GÜTÜRKÜN, ${ }^{14}$ DIANE W. LEE ${ }^{15}$ CLAUDIO V. MELLO,${ }^{16}$ \\ ALICE POWERS, ${ }^{17}$ STEPHANIE A. WHITE, ${ }^{18}$ GERALD HOUGH, ${ }^{19}$ \\ LUBICA KUBIKOVA, ${ }^{20}$ TOM V. SMULDERS, ${ }^{21}$ KAZUHIRO WADA, ${ }^{20}$ \\ JENNIFER DUGAS-FORD, ${ }^{22}$ SCOTT HUSBAND,${ }^{9}$ KEIKO YAMAMOTO, ${ }^{1}$ JING YU, ${ }^{20}$ \\ CONNIE SIANG, ${ }^{20}$ AND ERICH D. JARVIS ${ }^{20 *}$ \\ ${ }^{1}$ Department of Anatomy and Neurobiology, University of Tennessee Health Science Center, \\ Memphis, Tennessee 38163 \\ ${ }^{2}$ Departments of Biology and Otolaryngology, University of Washington, \\ Seattle, Washington 98195-6515 \\ ${ }^{3}$ Department of Biomedical Sciences, Creighton University School of Medicine, \\ Omaha, Nebraska 68178 \\ ${ }^{4}$ Krasnow Institute and Department of Psychology, George Mason University, \\ Fairfax, Virginia 22030-4444 \\ ${ }^{5}$ Department of Anatomy, Semmelweis University, Faculty of Medicine, \\ H-1094, Budapest, Hungary \\ ${ }^{6}$ Department of Poultry Science, Poultry Science Center, University of Arkansas, \\ Fayetteville, Arkansas 72701 \\ ${ }^{7}$ Department of Human Anatomy, Faculty of Medicine, University of Murcia, \\ Murcia E-30100, Spain \\ ${ }^{8}$ Prince of Wales Medical Research Institute, Sydney, New South Wales 2031, Australia \\ ${ }^{9}$ Department of Psychology, University of South Florida, Tampa, Florida 33620-8200 \\ ${ }^{10}$ Department of Neurobiology and Behavior, University of California at Irvine, \\ Irvine, California 92697-4550 \\ ${ }^{11}$ Division of Anatomy, Faculty of Medical and Health Sciences, University of Auckland, \\ Auckland 92019, New Zealand \\ ${ }^{12}$ Department of Psychological and Brain Sciences, Johns Hopkins University, \\ Baltimore, Maryland 21218 \\ ${ }^{13}$ Department of Biology, Queens College-City University of New York, Flushing, \\ New York 11367-1597 \\ ${ }^{14}$ Department of Biopsychology, Institute of Cognitive Neuroscience, Faculty of Psychology, \\ Ruhr-Universität Bochum, 44780 Bochum, Germany \\ ${ }^{15}$ Department of Psychology, California State University, Long Beach, California 90840-0901 \\ ${ }^{16}$ Neurological Sciences Institute, Oregon Health and Science University, West Campus, \\ Beaverton, Oregon 97006-3499 \\ ${ }^{17}$ Department of Psychology, St John's University, Jamaica, New York 11439 \\ ${ }^{18}$ Department of Physiological Science, University of California, Los Angeles, \\ Los Angeles, California 90095-1606 \\ ${ }^{19}$ Department of Psychology, Bowling Green State University, \\ Bowling Green, Ohio 43403 \\ ${ }^{20}$ Department of Neurobiology, Duke University Medical Center, \\ Durham, North Carolina 27710 \\ ${ }^{21}$ School of Biology, University of Newcastle, Newcastle upon Tyne \\ NE2 4HH, United Kingdom \\ ${ }^{22}$ Department of Organismal Biology and Anatomy, University of Chicago, \\ Chicago, Illinois 60637
}

Grant sponsor: National Science Foundation; Grant number: IBN0110894; Grant sponsor: National Institutes of Health; Grant number: 1R13-MH-64400-01.

*Correspondence to: Anton Reiner, Department of Anatomy \& Neurobiology, University of Tennessee Health Science Center, 855 Monroe Avenue, Memphis, TN 38163; E-mail: areiner@utmem.edu and/or Erich D. Jarvis,
Department of Neurobiology, Box 3209, Duke University Medical Center, Durham, North Carolina 27710; E-mail: jarvis@neuro.duke.edu Received 18 April 2003; Revised 11 December 2003; Accepted 21 January 2004 DOI 10.1002/cne.20118

Published online in Wiley InterScience (www.interscience.wiley.com). 
ABSTRACT

The standard nomenclature that has been used for many telencephalic and related brainstem structures in birds is based on flawed assumptions of homology to mammals. In particular, the outdated terminology implies that most of the avian telencephalon is a hypertrophied basal ganglia, when it is now clear that most of the avian telencephalon is neurochemically, hodologically, and functionally comparable to the mammalian neocortex, claustrum, and pallial amygdala (all of which derive from the pallial sector of the developing telencephalon). Recognizing that this promotes misunderstanding of the functional organization of avian brains and their evolutionary relationship to mammalian brains, avian brain specialists began discussions to rectify this problem, culminating in the Avian Brain Nomenclature Forum held at Duke University in July 2002, which approved a new terminology for avian telencephalon and some allied brainstem cell groups. Details of this new terminology are presented here, as is a rationale for each name change and evidence for any homologies implied by the new names.

Revisions for the brainstem focused on vocal control, catecholaminergic, cholinergic, and basal ganglia-related nuclei. For example, the Forum recognized that the hypoglossal nucleus had been incorrectly identified as the nucleus intermedius in the Karten and Hodos (1967) pigeon brain atlas, and what was identified as the hypoglossal nucleus in that atlas should instead be called the supraspinal nucleus. The locus ceruleus of this and other avian atlases was noted to consist of a caudal noradrenergic part homologous to the mammalian locus coeruleus and a rostral region corresponding to the mammalian A8 dopaminergic cell group. The midbrain dopaminergic cell group in birds known as the nucleus tegmenti pedunculopontinus pars compacta was recognized as homologous to the mammalian substantia nigra pars compacta and was renamed accordingly; a group of $\gamma$-aminobutyric acid (GABA)ergic neurons at the lateral edge of this region was identified as homologous to the mammalian substantia nigra pars reticulata and was also renamed accordingly. A field of cholinergic neurons in the rostral avian hindbrain was named the nucleus pedunculopontinus tegmenti, whereas the anterior nucleus of the ansa lenticularis in the avian diencephalon was renamed the subthalamic nucleus, both for their evident mammalian homologues.

For the basal (i.e., subpallial) telencephalon, the actual parts of the basal ganglia were given names reflecting their now evident homologues. For example, the lobus parolfactorius and paleostriatum augmentatum were acknowledged to make up the dorsal subdivision of the striatal part of the basal ganglia and were renamed as the medial and lateral striatum. The paleostriatum primitivum was recognized as homologous to the mammalian globus pallidus and renamed as such. Additionally, the rostroventral part of what was called the lobus parolfactorius was acknowledged as comparable to the mammalian nucleus accumbens, which, together with the olfactory tubercle, was noted to be part of the ventral striatum in birds. A ventral pallidum, a basal cholinergic cell group, and medial and lateral bed nuclei of the stria terminalis were also recognized.

The dorsal (i.e., pallial) telencephalic regions that had been erroneously named to reflect presumed homology to striatal parts of mammalian basal ganglia were renamed as part of the pallium, using prefixes that retain most established abbreviations, to maintain continuity with the outdated nomenclature. We concluded, however, that one-to-one (i.e., discrete) homologies with mammals are still uncertain for most of the telencephalic pallium in birds and thus the new pallial terminology is largely devoid of assumptions of one-to-one homologies with mammals. The sectors of the hyperstriatum composing the Wulst (i.e., the hyperstriatum accessorium intermedium, and dorsale), the hyperstriatum ventrale, the neostriatum, and the archistriatum have been renamed (respectively) the hyperpallium (hypertrophied pallium), the mesopallium (middle pallium), the nidopallium (nest pallium), and the arcopallium (arched pallium). The posterior part of the archistriatum has been renamed the posterior pallial amygdala, the nucleus taeniae recognized as part of the avian amygdala, and a region inferior to the posterior paleostriatum primitivum included as a subpallial part of the avian amygdala. The names of some of the laminae and fiber tracts were also changed to reflect current understanding of the location of pallial and subpallial sectors of the avian telencephalon. Notably, the lamina medularis dorsalis has been renamed the pallial-subpallial lamina. We urge all to use this new terminology, because we believe it will promote better communication among neuroscientists. Further information is available at http://avianbrain.org. J. Comp. Neurol. 473:377-414, $2004 . \quad \odot 2004$ Wiley-Liss, Inc.

Indexing terms: pallium; basal ganglia; telencephalon; brainstem; evolution; terminology; birds; mammals 
The various structures of the human brain were typically named for their shape, appearance, or position, and then these names were applied to the presumed homologous structures in nonhuman mammals, even if the descriptive implications were inappropriate for the given nonhuman species. For example, in rodents, the substantia nigra is not black and the dorsal lateral geniculate nucleus is not bent like a flexed knee, yet these terms have nonetheless been applied in rodents. The presumption has been that a communication benefit derives from calling homologous structures by the same name and that this benefit outweighs any descriptive or etymological incongruities. A similar benefit in parsimony and communication ensues if homologous structures are given the same names across classes. The issue of brain homology across classes was addressed, beginning more than 100 years ago, by Ludwig Edinger and his students in Germany, as part of an effort to understand vertebrate brain evolution (Edinger et al., 1903; Edinger, 1908). They, and later others such as J.B. Johnston, G.C. Huber, E.C. Crosby, C.U. Ariëns-Kappers, and C.J. Herrick, developed a theory of vertebrate brain evolution based on studies of cellstained and fiber-stained sections of fish, amphibian, reptilian, avian, and mammalian brains. This theory postulated that the brain had evolved by a stepwise addition of parts (reminiscent of Buffon's Scala Naturae view of animal intelligence) and a gradual transfer of function from mesencephalic to ventral telencephalic, and ultimately to dorsal telencephalic centers (a process called encephalization; Buffon, 1749; Ariëns-Kappers, 1922, 1928; Johnston, 1923; Ariëns-Kappers et al., 1936; Lovejoy, 1936; Herrick, 1948, 1956).

Of present relevance is their interpretation of telencephalic evolution and the impact of this view on the terminology that came to be widely employed for the telencephalon of birds (Fig. 1A,B). In this view, the telencephalon of stem reptiles (now called stem amniotes) was thought to have consisted of a meager cortical mantle (the pallium) and a disproportionately large basal ganglia. In the evolution of stem amniotes into mammals, the meager cortical mantle was considered to have become enormously hypertrophied and elaborated into the neocortex. In contrast, in the lineage leading to birds, the basal ganglia was presumed to have grown in size and complexity, because a laminated structure resembling mammalian neocortex was not evident (Fig. 2A,C). The divergence between birds and mammals in the part of the telencephalon assumed to have elaborated was taken to explain the presumed differences in behavior between birds and mammals. Mammals were considered to possess a flexible, learned behavioral repertoire, and it was widely presumed that a neocortex was uniquely necessary for such abilities, whereas the complex behaviors of birds were commonly thought to be entirely instinctive, because it was thought that the basal ganglia controlled instinctive behavior (Elliot-Smith, 1901; Edinger, 1908; Herrick, 1956).

The specific view of telencephalic evolution that thus came to be widespread during the first 60 years of the 20 th century was that both birds and mammals shared several basal ganglia structures, namely, an older structure inherited from fish called the paleostriatum primitivum (now called the globus pallidus in mammals) and a newer basal ganglia structure evolved in amphibians, but expanded in reptiles and more so in birds, called the neostriatum (considered equivalent to most of the caudate and putamen of mammals by Ariëns-Kappers et al. [1936], but now used to refer to the entire caudatoputamen; Fig. 1A,B). Reptiles were thought to have also elaborated the two parts of the fish paleostriatum, the primitivum and the augmentatum (the latter considered by AriënsKappers et al. to include primitive parts of the mammalian caudate and putamen) into two clearly distinct regions and to have passed this trait on to birds (Fig. 1A,B). Finally, the neostriatum in birds was thought to have given rise to a novel overlying structure called the hyperstriatum (Fig. 1A,B). Birds and mammals were also thought to share a caudobasal subcortical structure termed the archistriatum (Ariëns-Kappers, 1922, 1928), in mammals now called the amygdala. Although some investigators such as Kuhlenbeck (1938), Rose (1914), and Källén (1953) dissented from these views, the accretionary theory of vertebrate brain evolution, as espoused in major books by Ariëns-Kappers et al. (1936) and Herrick (1948, 1956), became the prevailing view and led to the predominant use of the terms neostriatum, archistriatum, and hyperstriatum to refer to the major telencephalic sectors above the paleostriatum in birds, and to the term neocortex for the major pallial sector of the telencephalon in mammals.

In 1967, Karten and Hodos published their stereotaxic atlas of the pigeon brain, which provided the first comprehensive effort to identify and name all parts of the brain in birds. In their Introduction, they describe the process by which they chose the terminology they used. For the hindbrain and midbrain, they adapted the terminology for the mammalian brainstem developed by Olszewski and coworkers (Meessen and Olzsewski, 1949; Olszewski and Baxter, 1954). For the pretectum and thalamus, they relied on the avian terminology of Kuhlenbeck (1937, 1939), Huber (1929), and Craigie (1931). For the telencephalon, they expressed concern that use of terms such as archistriatum, neostriatum, and hyperstriatum, as per AriënsKappers et al. (1936), could promote the notion that the telencephalon in birds is composed almost entirely of a highly developed basal ganglia, which they regarded as unlikely, based on developmental studies by Källén (1953) and Haefelfinger (1957). Although they noted that other telencephalic terminologies had been suggested for birds, such as the descriptive terminology of Kuhlenbeck (1938), or the letter-based terminology of Rose (1914), Karten and Hodos ultimately decided to employ the evolution-based nomenclature of Ariëns-Kappers et al. (1936), which was a revision of Edinger's terminology (Edinger et al., 1903; Edinger, 1908), for the major subdivisions of the telencephalon in birds, because this terminology was already entrenched.

Subsequent atlases for other avian species (Stokes et al., 1974; Youngren and Philips, 1983; Kuenzel and Masson, 1988; Matochik et al., 1991) largely used the same terminology as Karten and Hodos, leading to standardization of avian brain nomenclature. Although much of the terminology used in Karten and Hodos (1967) has stood the test of time, many interpretations of telencephalic homology implied by the terminology of Ariëns-Kappers et al. (1936) that Karten and Hodos (1967) had already suspected to be flawed have since been overwhelmingly shown to be erroneous (Figs. 1C, 2A-F). In particular, the notion that most of the telencephalon in birds is a hypertrophied basal ganglia has been disproved, because it is now clear that most of the telencephalon in birds is neu- 

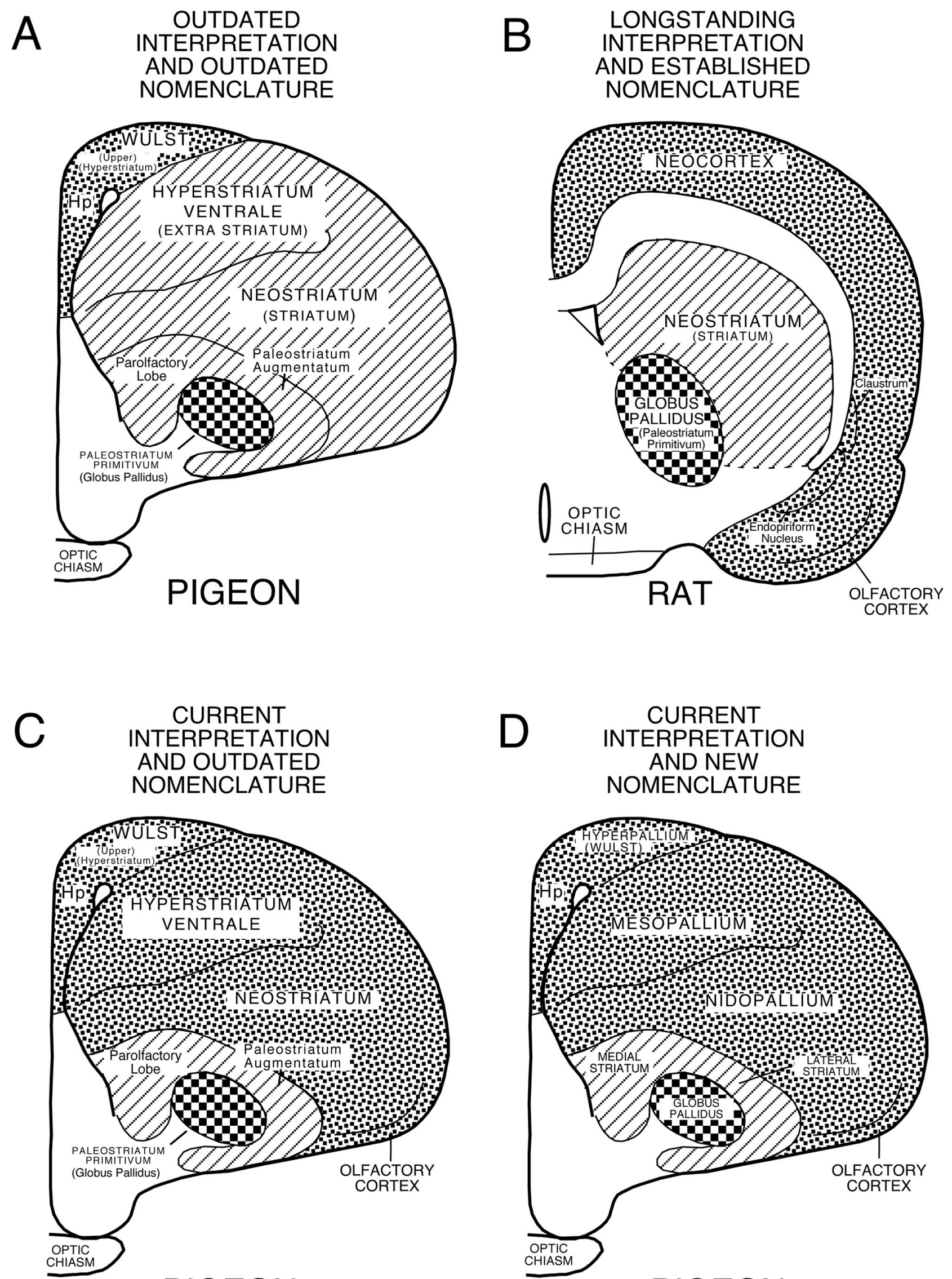

PIGEON

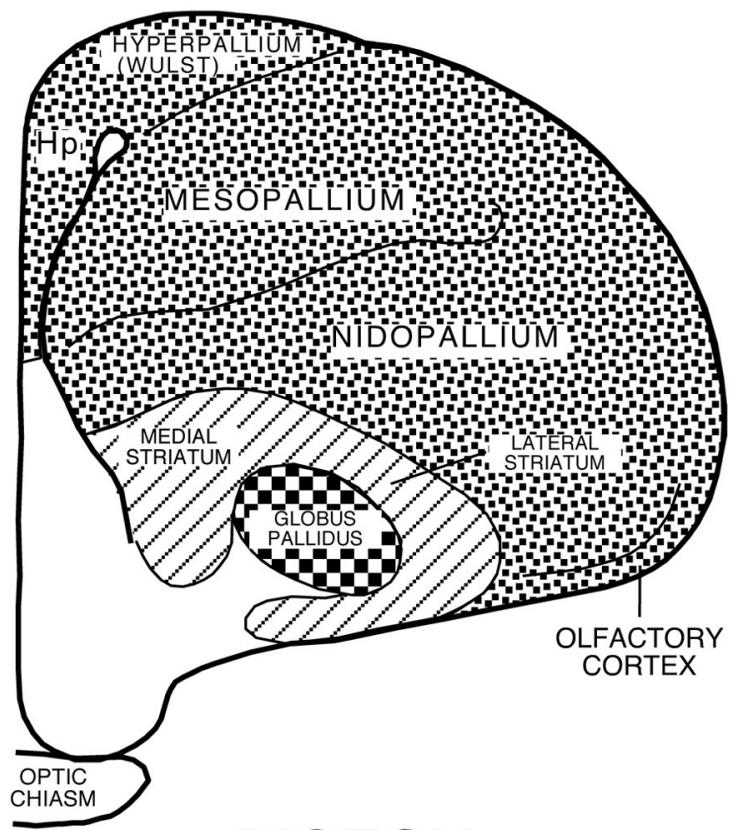

PIGEON 
rochemically, hodologically, and functionally comparable to the mammalian neocortex, claustrum, and pallial amygdala (all of which derive from the pallial sector of the developing telencephalon; Karten, 1969; Reiner et al., 1998a; Puelles et al., 2000). Additionally, the mammalian homologues of some brainstem cell groups connected with the telencephalon, which were not known at the time the Karten and Hodos atlas was completed, have been demonstrated. As deeper insight has been gained into the evolution, development, and function of avian and mammalian brains, it has become clear that the flawed homologies implied by the Ariëns-Kappers et al. (1936) terminology for the telencephalon of birds, as well as some now evident errors in brainstem terminology, make findings on avian brains confusing or inaccessible to researchers working on other species and perpetuate an outdated view of avian brain evolution, as well as vertebrate brain evolution in general.

This issue came to be of growing concern to avian neurobiologists, in part because of increased research focusing on avian brains. Formal efforts to revise avian brain nomenclature were begun 6 years ago by a small group of avian brain specialists. To develop widely acceptable new terms, this group sought to involve a greater number of researchers than had participated in two previous attempts to standardize avian neuroanatomical terms (Baumel, 1979, 1993). Accordingly, the group eventually grew to an international collection of multidisciplinary neuroscientists, and 2 years ago the group decided to hold an open Brain Nomenclature Forum, at which a new terminology would be adopted. This Forum was held July 18-20, 2002 at Duke University in Durham, North Carolina, and was attended by the authors of this paper. The Forum was preceded by in-depth discussions by E-mail and telephone of specific recommendations as to possible new terms. This manuscript presents the new terminology approved by the Forum, as well as the major evidence for the new terminology. A companion manuscript avail-

Fig. 1. A series of schematic line drawings of midtelencephalic transverse brain sections of pigeon and rat. A: The outdated interpretation of the organization of the telencephalon in birds (AriënsKappers et al., 1936) and the outdated nomenclature that view engendered for the telencephalon of birds. B: The longstanding interpretation of mammalian telencephalic organization and the established nomenclature consistent with that view. C; the current interpretation of the organization of avian telencephalon and the outdated avian telencephalic nomenclature, which highlights the inappropriateness of this nomenclature. D: The current interpretation of the organization of avian telencephalon and new avian telencephalic nomenclature adopted by the Avian Brain Nomenclature Forum that is consistent with current findings on telencephalic organization in birds. In each schematic interpretation of telencephalic organization, the speckled region represents pallium, the striped region represents striatum, and the checked region represents globus pallidus. As indicated by a comparison of A and B, the terms used for specific telencephalic regions in birds were seemingly appropriate at the time that most of the telencephalon of birds was thought to represent a hypertrophied basal ganglia (Ariëns-Kappers et al., 1936). Now that it is clear that the telencephalon of birds includes both a basal ganglia and a large pallial territory comparable in their relative extents to those in mammals (B compared to $\mathrm{C}$ ), the names for pallial regions implying striatal homology are inappropriate and misleading. Moreover, even the terms for the basal ganglia itself are uninformative and potentially misleading and were thus in need of revision. The new terminology (D) avoids such misimpressions. Hp, hippocampus. able on-line describes in more detail the pre-Forum preparatory period and the Forum logistics (http://www. interscience.wiley.com/jpages/0021-9967/suppmat/ index.html). Details of the discussion and decisionmaking process will be published in a special issue of Brain, Behavior and Evolution devoted to the nomenclature change.

For each structure listed in the following sections, the old name is given first, followed by an arrow pointing to the new name. The old and new names for each structure are also shown in Tables 1-7, together with Latin and English versions of the new name and the abbreviations for each. The new names for several major telencephalic sectors are also schematized in Figure 1D. The old names and abbreviations used are those that are most commonly used in the published literature for each given structure. In instances in which the new avian name indicates homology to a given mammalian structure, the new names and abbreviations recommended by the Forum are those that are most commonly used in the mammalian literature. In the case of structures for which an entirely new name has been adopted by the Forum, terms close in form to the outdated names were typically selected (e.g., arcopallium as the new term to replace archistriatum). Abbreviations follow the rule that the first letters of the words represented in the abbreviation be capitalized, and only subordinate letters (e.g., second letter of a word) or letters representing subordinate words (such as the ventralis of pars ventralis) be in lower case.

\section{REVISED BRAINSTEM TERMINOLOGY}

\section{General considerations}

The Forum focused on several brainstem cell groups connected with the basal ganglia or the song system (Table 1), for which the homology implied by the name was clearly incorrect, or at best obscure, and the true homologue is now amply demonstrated. These structures, new terms, and evidence for homology accepted by the Forum are detailed below on a structure-by-structure basis. The old and new names for these brainstem cell groups are also shown in Table 1.

\section{Rationale for individual changes}

Nucleus intermedius (IM) $\rightarrow$ Hypoglossal nucleus (nXII). In the Karten and Hodos pigeon brain atlas, a population of motoneurons located ventral to the dorsal motor nucleus of the vagus nerve and the nucleus intercalatus at levels straddling the obex was named the nucleus intermedius, following the practice of earlier workers (Ariëns-Kappers et al., 1936). Because this nucleus is now known to innervate tongue, tracheal, and syringeal muscles via the lingual and tracheosyringeal branches of the 12th nerve (Hillebrand, 1971; Nottebohm et al., 1976; Wild and Zeigler, 1980; Wild, 1981; Eden and Correia, 1982; Youngren and Phillips, 1983; Vicario and Nottebohm, 1988; Dubbeldam and Bout, 1990; Wild, 1990), the Nomenclature Forum decided to formally endorse the renaming of the nucleus intermedius of Karten and Hodos as the hypoglossal nucleus, or nXII (Table 1, Fig. 3A). The correct name for this cell group had already been routinely used for many years in various publications (e.g., Nottebohm et al., 1976; Medina and Reiner, 1994) but had not yet been formally adopted. 

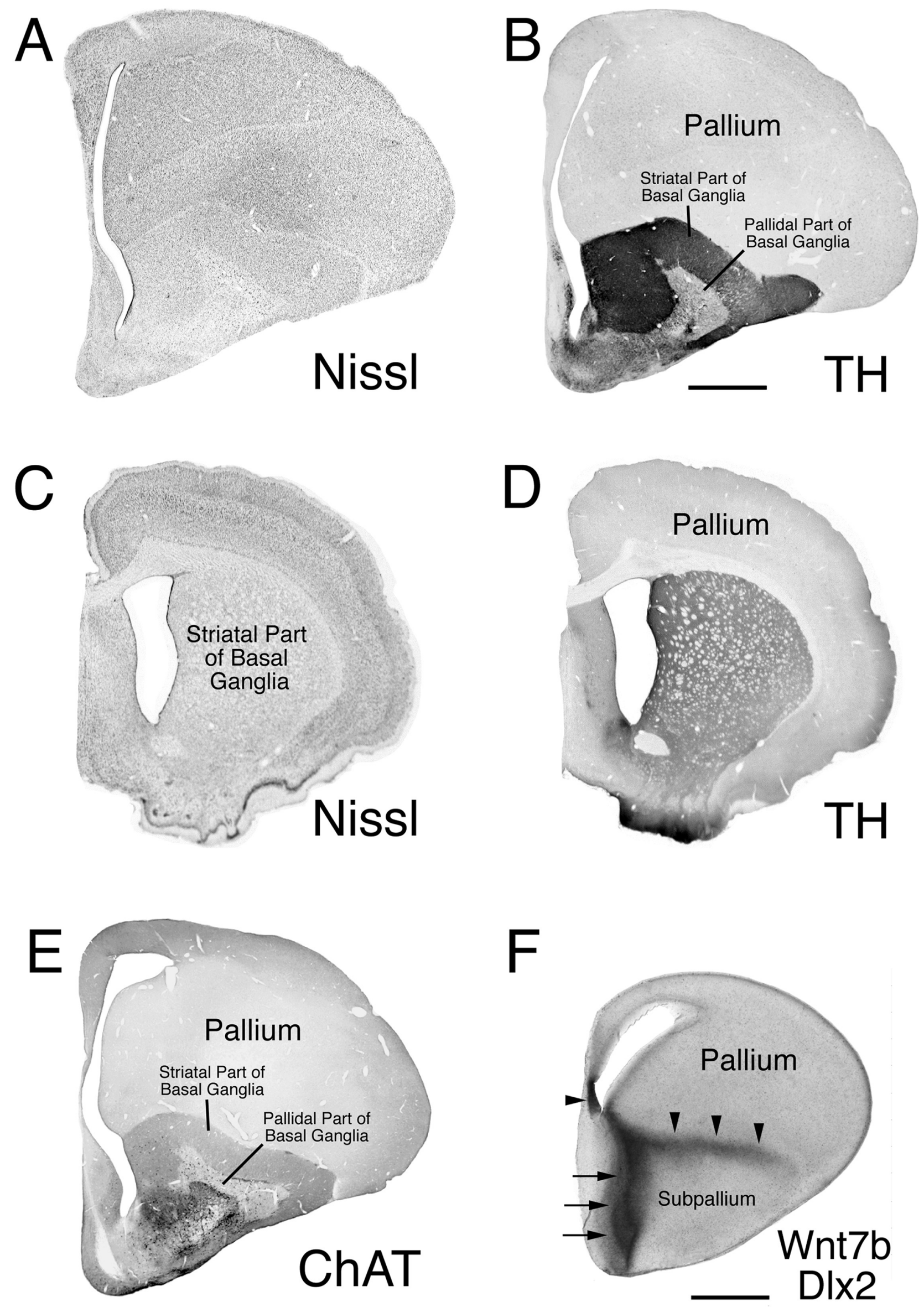

Figure 2 
Nucleus nervi hypoglossi (nXII) $\rightarrow$ Supraspinal nucleus (SSp). A population of motoneurons ventral to the nucleus intermedius of Karten and Hodos (1967) and abutting the lateral edge of the medial longitudinal fasciculus was identified in their atlas as the hypoglossal nucleus. This group of motoneurons is made up of dorsomedial and ventrolateral clusters, both of which are now known to innervate upper neck muscles, but not the tongue (Wild, 1981; Eden and Correia, 1982; Watanabe and Ohmori, 1988; Horster et al., 1990; Zijlstra and Dubbeldam, 1994). This cell group is separate from an upper cervical spinal cord nucleus from which the accessory nerve arises (Beccari, 1943; Hillebrand, 1975; Wild, 1981; Zijlstra and Dubbeldam, 1994). The Nomenclature Forum therefore decided to rename this cell group formally as the nucleus supraspinalis, the name that had been employed in several studies subsequent to the publication of the Karten and Hodos atlas (Hillebrand, 1975; Wild and Zeigler, 1980; Wild, 1981) (Table 1, Fig. 3A).

Caudal locus ceruleus $\rightarrow$ Locus coeruleus $(\mathrm{LoC})$. In the Karten and Hodos (1967) atlas, the locus ceruleus (or coeruleus) was identified as a large neuronal field extending from rostral pontine to caudal midbrain tegmental levels. Subsequent atlases in other avian species have followed this convention (Stokes et al., 1974; Youngren and Phillips, 1983; Kuenzel and Masson, 1988; Matochik et al., 1991). The LoC in mammals is a cell-dense nucleus containing neurons rich in noradrenaline (Moore and Card, 1984; Smeets and Reiner, 1994) that is restricted to rostral pontine levels and does not extend into the midbrain (Puelles and Medina, 1994). Immunohistochemical studies of various avian species over the past 15 years have shown that only the caudal part of what is identified as the LoC (i.e., the hindbrain part) in the Karten and

Fig. 2. A series of low-power images of transverse sections through the telencephalon of adult pigeon (A,B,E), adult rat (C,D), and developing chicken (F), labeled for various markers. A,C: Comparison of the Nissl-stained sections for pigeon and rat shows that the bird telencephalon conspicuously lacks a laminated structure resembling the mammalian cerebral cortex along its outer surface. Instead, much of the telencephalon of birds resembles the striatal part of the mammalian basal ganglia in its histological appearance. These features of the telencephalon in birds had led comparative neuroanatomists in the early part of the 20th century to conclude that the telencephalon in birds largely consisted of a hypertrophied basal ganglia (AriënsKappers et al., 1936). D: The striatum in mammals is characterized by enrichment in dopaminergic terminals arising from neurons in the midbrain tegmentum, as well as by enrichment in cholinergic terminals (not shown) arising from intrinsic striatal neurons. B,E: Immunolabeling of pigeon striatum for a marker of dopaminergic terminals (tyrosine hydroxylase, TH) or a marker of cholinergic terminals (choline acetyltransferase, ChAT) reveals that only the basal part of the telencephalon in birds possesses these traits and is therefore the only part of the telencephalon in birds that is striatal in nature. F: The image of an E10 chick embryo telencephalon reinforces this view. The section had been double-labeled by in situ hybridization histochemistry for Dlx2 (which is selectively expressed by subpallial neurons at the subventricular zone during development) and Wnt7b (which is expressed by cells near the pallial-subpallial boundary). The Dlx2 labeling is located along the ventricular and subventricular zone of the lower part of the telencephalon (arrows), whereas Wnt7b is expressed along the upper aspect of the developing striatum (arrowheads). A small area of Wnt7b expression is also evident at the so-called cortical hem (arrowhead), at the edge of the hippocampus. (F, adapted from Garda et al., 2002). Scale bar $=2 \mathrm{~mm}$ in B (applies to $\mathrm{A}-\mathrm{E}) ; 0.5 \mathrm{~mm}$ in $\mathrm{F}$.
Hodos atlas contains noradrenergic neurons (von Bartheld and Bothwell, 1992; Bailhache and Balthazart, 1993; Reiner et al., 1994; Mello et al., 1998a) and is in the same topographic and segmental location as mammalian LoC (Puelles and Medina, 1994). A neurochemically and topologically identical cell group is present in the rostral hindbrain of reptiles (turtles, lizards, and snakes), as well as urodele and anuran amphibians (Gonzalez and Smeets, 1994; Medina et al., 1994; Smeets, 1994), and is considered homologous to the caudal part of the Karten and Hodos LoC in birds and the LoC of mammals (Smeets and Reiner, 1994). Thus, the Forum redefined the LoC in birds as the noradrenergic cell field at the lateral edge of the fourth ventricle at rostral pontine levels (Table 1, Figs. $3 \mathrm{~B}, 4 \mathrm{~A}, \mathrm{~B})$, with coeruleus rather than ceruleus being the recommended spelling due to its more common usage. It should be noted that for both birds and mammals the A6 cell group does not correspond exclusively to the cytoarchitectonically defined locus coeruleus, because the noradrenergic neurons of $\mathrm{A} 6$ extend somewhat ventral and rostral to the LoC (Dahlström and Fuxe, 1964; Hokfelt et al., 1984; von Bartheld and Bothwell, 1992; Reinger et al., 1994), and nearby fields of cholinergic and serotonergic neurons overlap somewhat with the LoC (Steinbusch, 1981; Mesulam et al., 1984; Steinbusch, 1984; Yamada et al., 1984; Vincent and Reiner, 1987; Coozi et al., 1991; Woolf, 1991; von Bartheld and Bothwell, 1992; Medina and Reiner, 1994). Nonetheless, the A6 largely coincides with the LoC, and noradrenergic neurons represent the predominant population in the LoC.

Rostral locus ceruleus $\rightarrow$ A8. The cell group identified in Karten and Hodos (1967) as the rostral part of the LoC (i.e., the LoC at levels A2.75-A2.25 of the pigeon brain atlas) actually corresponds to the midbrain A8 dopaminergic cell group. Studies of various avian species over the past 15 years have established that neurons in the rostral (i.e., midbrain) part of what was termed the LoC in the Karten and Hodos atlas are dopaminergic rather than noradrenergic (Smeets, 1991; Bailhache and Balthazart, 1993; Reiner et al., 1994). They coincide topographically with the A8 cell group of mammals and show the same continuity with the SNc/A9 group as does the A8 of mammals. Developmental studies further reinforce the conclusion that the rostral part of what was called the LoC in the Karten and Hodos atlas is the A8 (Puelles and Medina, 1994). A distinct A8 with similar neurochemical and topographic traits as those of birds and mammals also is characteristic of reptiles (turtles, lizards, and snakes) and urodele and anuran amphibians (Gonzalez and Smeets, 1994; Smeets, 1994; Smeets and Reiner, 1994). Thus, the Forum renamed the rostral part of what had been called the LoC in birds as the A8 (Table 1, Figs. 3C, $4 \mathrm{C}, \mathrm{D})$. One further issue of concern was whether the avian A8 cell group should also be given the same common name as the A8 cell group in mammals, namely, the retrorubral nucleus. We decided that although this might be useful for further emphasizing the homology to mammals, the A8 in birds is not truly retrorubral in position, and the name was thus potentially misleading. Additionally, the A8 is but one of the cellular occupants of the retrorubral region in mammals (Hokfelt et al., 1984; Kitahama et al., 1994; Paxinos and Watson, 1998), and use of this name for birds would imply homologies beyond that to the A8 population, homologies that at this time have not been investigated. 
TABLE 1. New Terminology for Brainstem Cell Groups

\begin{tabular}{|c|c|c|c|c|}
\hline $\begin{array}{l}\text { Structure and Karten- } \\
\text { Hodos (or other) term } \\
\text { for structure } \\
\text { (abbreviation) }\end{array}$ & $\begin{array}{l}\text { Latin Name adopted } \\
\text { by Forum } \\
\text { (abbreviation) }\end{array}$ & $\begin{array}{l}\text { English name } \\
\text { adopted by Forum } \\
\text { (abbreviation) }\end{array}$ & Comments & $\begin{array}{l}\text { Refs. pertinent to the } \\
\text { new name }\end{array}$ \\
\hline $\begin{array}{l}\text { Nucleus intermedius of } \\
\text { the medulla in Karten } \\
\text { and Hodos (IM) }\end{array}$ & $\begin{array}{l}\text { Nucleus nervi hypoglossi } \\
\text { (nXII) }\end{array}$ & $\begin{array}{l}\text { Hypoglossal nucleus-the } \\
\text { 12th cranial nerve } \\
\text { nucleus (nXII) }\end{array}$ & $\begin{array}{l}\text { This naming error in the } \\
\text { Karten and Hodos atlas } \\
\text { has long been known }\end{array}$ & $\begin{array}{l}\text { Nottebohm et al., } 1976 \\
\text { Wild and Zeigler, } 1980 \\
\text { Wild, } 1981\end{array}$ \\
\hline $\begin{array}{l}\text { Nucleus nervi hypoglossi } \\
\text { in Karten and Hodos } \\
\text { (nXII) }\end{array}$ & $\begin{array}{l}\text { Nucleus supraspinalis } \\
\text { (SSp) }\end{array}$ & $\begin{array}{l}\text { Supraspinal nucleus } \\
\text { (SSp) }\end{array}$ & $\begin{array}{l}\text { This naming error in } \\
\text { Karten and Hodos atlas } \\
\text { has long been known }\end{array}$ & $\begin{array}{l}\text { Wild, } 1981 \\
\text { Eden and Correia, } 1982 \\
\text { Zijlstra and Dubbeldam, } 1994\end{array}$ \\
\hline $\begin{array}{l}\text { Locus ceruleus-caudal } \\
\text { part (caudal LoC) }\end{array}$ & $\begin{array}{l}\text { Locus coeruleus with } \\
\text { locus ceruleus being a } \\
\text { less common but also } \\
\text { acceptable spelling } \\
\text { (LoC) }\end{array}$ & $\begin{array}{l}\text { Locus coeruleus, locus } \\
\text { ceruleus, or A6 (LoC or } \\
\text { A6) }\end{array}$ & $\begin{array}{l}\text { Noradrenergic neurons of } \\
\text { A6 as defined by } \\
\text { Dahlström and Fuxe, } \\
1984\end{array}$ & $\begin{array}{l}\text { Kitt and Brauth, 1986a } \\
\text { Bailhache and Balthazart, } 1993 \\
\text { Reiner et al., } 1994 \\
\text { Von Bartheld and Bothwell, } 1992\end{array}$ \\
\hline $\begin{array}{l}\text { Locus ceruleus-rostral } \\
\text { part (rostral LoC) }\end{array}$ & None (none) & A8 (A8) & $\begin{array}{l}\text { Dopaminergic neurons of } \\
\text { A8 as defined by } \\
\text { Dahlström and Fuxe, } \\
1984\end{array}$ & $\begin{array}{l}\text { Von Bartheld and Bothwell, } 1992 \\
\text { Reiner et al., } 1994 \\
\text { Puelles and Medina, } 1994 \\
\text { Smeets and Reiner, } 1994\end{array}$ \\
\hline $\begin{array}{l}\text { Nucleus tegmenti- } \\
\text { pedunculopontinus, } \\
\text { pars compacta, except } \\
\text { lateral edge (TPc, } \\
\text { except for lateral edge) }\end{array}$ & $\begin{array}{l}\text { Substantia nigra, pars } \\
\text { compacta (SNc) }\end{array}$ & $\begin{array}{l}\text { Substantia nigra, pars } \\
\text { compacta or A9 (SNc or } \\
\text { A9) }\end{array}$ & $\begin{array}{l}\text { Dopaminergic neurons of } \\
\text { A9 as defined by } \\
\text { Dahlström and Fuxe, } \\
1984\end{array}$ & $\begin{array}{l}\text { Lewis et al., } 1981 \\
\text { Kill and Brauth, 1986b } \\
\text { Bailhache and Balthazart, } 1993 \\
\text { Reiner et al., } 1994 \\
\text { Puelles and Medina, } 1994 \\
\text { Smeets and Reiner, } 1994\end{array}$ \\
\hline $\begin{array}{l}\text { Lateral edge of nucleus } \\
\text { tegmenti- } \\
\text { pedunculopontinus, pars } \\
\text { compacta, plus small } \\
\text { area lateral to it (lateral } \\
\text { part of TPc and a small } \\
\text { region lateral to it) }\end{array}$ & $\begin{array}{l}\text { Substantia nigra, pars } \\
\text { reticulata }(\mathrm{SNr})\end{array}$ & $\begin{array}{l}\text { Substantia nigra, pars } \\
\text { reticulata (SNr) }\end{array}$ & $\begin{array}{l}\text { Previously called } \\
\text { substantia nigra, pars } \\
\text { lateralis in birds, but } \\
\text { switching to } \mathrm{SNr} \\
\text { indicates homology to } \\
\text { mammal SNr }\end{array}$ & $\begin{array}{l}\text { Veenman and Reiner, } 1994 \\
\text { Reiner et al., } 1998 \\
\text { Medina and Reiner, } 1997\end{array}$ \\
\hline $\begin{array}{l}\text { Area ventralis (Tsai) } \\
\text { (AVT) }\end{array}$ & $\begin{array}{l}\text { Area ventralis tegmenti } \\
\text { (AVT) }\end{array}$ & $\begin{array}{l}\text { Ventral tegmental area } \\
\text { or A10 (VTA or A10) }\end{array}$ & $\begin{array}{l}\text { Dopaminergic neurons of } \\
\text { A10 as defined by } \\
\text { Dahlström and Fuxe, } \\
1984\end{array}$ & $\begin{array}{l}\text { Lewis, et al., } 1981 \\
\text { Bailhache and Balthazart, } 1993 \\
\text { Reiner et al., } 1994 \\
\text { Puelles and Medina, } 1994 \\
\text { Smeets and Reiner, } 1994\end{array}$ \\
\hline $\begin{array}{l}\text { Partly identified as } \\
\text { nucleus profundus } \\
\text { mesencephali pars } \\
\text { ventralis (partly } \\
\text { identified as MPv) }\end{array}$ & $\begin{array}{l}\text { Nucleus } \\
\text { pedunculopontinus } \\
\text { tegmenti (PPT) }\end{array}$ & $\begin{array}{l}\text { Pedunculopontine } \\
\text { tegmental nucleus } \\
\text { (PPT) }\end{array}$ & $\begin{array}{l}\text { Cholinergic cell group of } \\
\text { isthmic region; English } \\
\text { term commonly used }\end{array}$ & $\begin{array}{l}\text { Medina and Reiner, } 1994 \\
\text { Woolf, } 1991\end{array}$ \\
\hline $\begin{array}{l}\text { Region medial to ansa } \\
\text { lenticularis identified as } \\
\text { anterior nucleus of ansa } \\
\text { lenticularis in Karten } \\
\text { and Dubbeldam, } 1973 \\
\text { (ALa) }\end{array}$ & $\begin{array}{l}\text { Nucleus subthalamicus } \\
\text { (STN) }\end{array}$ & $\begin{array}{l}\text { Subthalamic nucleus } \\
\text { (STN) }\end{array}$ & $\begin{array}{l}\text { English term more } \\
\text { commonly used for } \\
\text { mammals }\end{array}$ & $\begin{array}{l}\text { Reiner et al., } 1998 \\
\text { Jiao et al., } 2000\end{array}$ \\
\hline
\end{tabular}

${ }^{1}$ Summary of the nomenclature recommendations of the Forum for a number of brainstem cell groups related by connectivity to the basal ganglia or to the song control system, listed in a caudal to rostral order. For each structure considered, the first column of the table shows the original name assigned (typically from Karten and Hodos, 1967) and the original abbreviation, the next column shows the Latin variant and abbreviation of the new (or carried over) term recommended by the Forum, the next shows the English variant and abbreviation of the new (or carried over) recommended term, and the final two columns present any noteworthy comments about the change and key references pertinent to the change.

Nucleus tegmenti pedunculopontinus pars compacta (TPc) $\rightarrow$ Substantia nigra pars compacta (SNc). Some areas of the brainstem in birds have names that produce confusion because of implied similarity to nonhomologous areas of the mammalian brainstem. This is the case for the nucleus tegmenti pedunculopontinus pars compacta, located in the diencephalic-mesencephalic tegmentum (Puelles and Medina, 1994). This cell field contains a large population of dopaminergic neurons that send a massive dopaminergic innervation to the striatal part of the basal ganglia in birds (i.e., the regions that have been called lobus parolfactorius and paleostriatum augmentatum; Kitt and Brauth, 1986a,b; Bailhache and Balthazart, 1993; Reiner et al., 1994; Szekely et al., 1994; Karle et al., 1996; Metzger et al., 1996; Durstewitz et al., 1999) and therefore is accepted as homologous to the substantia nigra pars compacta of other vertebrates (Puelles and Medina, 1994; Smeets and Reiner, 1994; Medina and Reiner, 1995; Reiner et al., 1998a). The name applied to this region in Karten and Hodos (1967) and in many subsequent atlases and published papers, however, incorrectly suggests a homology with the pedunculopontine tegmental nucleus of mammals, located in rhombomere 1. This rhombomere gives rise to the rostral hindbrain region that includes the LoC, and it is characterized by the presence of numerous cholinergic neurons but no dopaminergic neurons (Medina and Reiner, 1994; Puelles and Medina, 1994). Moreover, the actual avian homologue of the mammalian pedunculopontine tegmental nucleus, which contains cholinergic neurons, has been identified in rhombomere 1 (Figs. 3F, 4E; Medina and Reiner, 1994), as detailed below in the section on this nucleus. To rectify these misnomers and avoid confusion, the Forum renamed what had been called the nucleus tegmenti pedunculopontinus pars compacta (TPc) in birds as the substantia nigra pars compacta $(\mathrm{SNc})$, or the A9 dopaminergic cell group (Table 1, Figs. 3D,F, 4F). Although the A9 dopaminergic neuron field in birds is not as compact as in rodents, or as pigmented as in humans, A9 varies in its compactness and blackness (i.e., pigmentedness) even among mammals. For this reason, and because of the gain in using a homology-based term for avian A9, the Forum decided that the descriptive inaccuracies of the terms "compacta" 
and "nigra" were far outweighed by the benefits obtained in adopting SNc as its common name.

Substantia nigra pars lateralis $(S N L) \rightarrow$ Substantia nigra pars reticulata ( $\mathbf{S N r}$ ). In mammals, the substantia nigra pars compacta lies dorsal to a dense field of fibers and terminals that arise from the striatal part of the basal ganglia, in which are embedded scattered GABAergic neurons (Reiner et al., 1998a). Because of the reticulated appearance imparted to this region by its fiber richness, it is called the substantia nigra pars reticulata $(\mathrm{SNr})$. The striatal terminals in mammalian $\mathrm{SNr}$ also are GABAergic, predominantly contain the neuropeptides substance $\mathrm{P}$ (SP) and dynorphin (DYN), and end on both the $\mathrm{SNr}$ GABAergic neurons and the dendrites of SNc dopaminergic neurons that extend into the $\mathrm{SNr}$ (Reiner et al., 1998a). The GABAergic neurons of the mammalian $\mathrm{SNr}$ project to the intermediate layers of the superior colliculus (which project to hindbrain premotor areas) and to the ventral anterior and ventrolateral thalamic nuclei (which project to motor cortices). By means of these projections, $\mathrm{SNr}$ neurons are involved in the basal ganglia-mediated control of movement (Reiner et al., 1998a). A similar GABAergic cell population has been identified in birds, lateral to and overlapping the SNc/A9 (Veenman and Reiner, 1994). This cell group was initially called the substantia nigra pars lateralis (Veenman and Reiner, 1994; Medina and Reiner, 1997), and it was shown to receive striatal input from SP/DYN-containing terminals of striatal origin and to project to the tectum and thalamus (Reiner et al., 1983; Anderson et al., 1991; Medina and Reiner, 1997; Reiner et al., 1998a). A similar cell group is also present in reptiles (turtles and crocodilians), supporting the homology of this cell group among amniotes (Brauth and Kitt, 1980; Reiner et al., 1980, 1998a; Brauth et al., 1983; Reiner and Carraway, 1987). The Forum thus concluded that the SNL of birds is homologous to the $\mathrm{SNr}$ in mammals and decided to rename avian SNL to $\mathrm{SNr}$ (Table 1, Figs. 3D,F, 4F). As with SNc, application of the term $\mathrm{SNr}$ to birds yields a slight descriptive misimpression, because this structure in birds is not as reticulated in appearance as in mammals and is not part of a field that contains black (i.e., pigmented) cells. The Forum decided that such inaccurate implications were outweighed by the benefits of adopting a homology-based term such as $\mathrm{SNr}$

Area ventralis of Tsai $(A V T) \rightarrow$ Ventral tegmental area (VTA). The area ventralis of Tsai of Karten and Hodos (1967) is considered homologous to the mammalian ventral tegmental area (Bailhache and Balthazart, 1993; Puelles and Medina, 1994, Reiner et al., 1994), which is also known as the A10 dopaminergic cell group and had once commonly been called the ventral tegmental area of Tsai (Crosby et al., 1962). As in mammals, the cell group in birds is dopaminergic, is situated near the oculomotor nerve as it exits the midbrain, is rostromedial to and continuous with the SNc/A9, and sends a massive dopaminergic projection to the basal ganglia, mainly to medial and ventral parts of the region that has been called the lobus parolfactorius (LPO; Lewis et al., 1981; Kitt and Brauth, 1986b, Bottjer, 1993; Reiner et al., 1994; Szekely et al., 1994). As for A9 and A8, a comparable cell group is present in all orders of reptiles (Smeets, 1994; Smeets and Reiner, 1994). For the purpose of abandoning the eponym Tsai (because eponyms are no longer employed according to international rules of anatomical nomenclature; Baumel, 1979, 1993) and formally adopting the term al- ready employed for mammals and in many recent studies in birds, the Forum approved the renaming of the avian area ventralis of Tsai as the ventral tegmental area, with the acceptable alternative name of A10. (Table 1, Figs. $3 \mathrm{D}, \mathrm{F}, 4 \mathrm{~F})$.

Undefined cholinergic cell group that occupies rostral hindbrain field partly overlapping nucleus profundus mesencephali pars ventralis (MPv) $\rightarrow$ Pedunculopontine tegmental nucleus (PPT). In mammals, a cholinergic cell group is located in the tegmentum of rhombomere 1, caudal to A9 and A8, as is easily seen in sagittal sections (Mesulam et al., 1984; Woolf, 1991). This cell group has been termed the pedunculopontine tegmental nucleus (also sometimes abbreviated as PPN). A similarly situated cholinergic cell group has been identified in chicken and pigeon (von Bartheld and Bothwell, 1992; Medina and Reiner, 1994), a rostroventral part of which overlaps what was called the nucleus profundus mesencephali pars ventralis in Karten and Hodos (1967). This cholinergic cell group closely resembles the mammalian pedunculopontine tegmental nucleus in its projections to the midbrain tectum, retinorecipient thalamic and pretectal nuclei, and telencephalon (Reiner et al., 1982; Medina and Reiner, 1994). A comparably situated cholinergic cell group has been recognized in turtles and lizards (Medina et al., 1993; Powers and Reiner, 1993), supporting the homology of this cell group among amniotes. The Forum thus recognized the existence of this cell group in birds and recommended that the same name be employed as for its mammalian homologue (Table 1, Figs. 3F, 4E).

Anterior nucleus of the ansa lenticularis (ALa) $\rightarrow$ Subthalamic nucleus (STN). The avian anterior nucleus of the ansa lenticularis is an inconspicuous cell group of the rostral diencephalon located in and along the medial edge of the ansa lenticularis (a fiber bundle interconnecting the basal ganglia with various brainstem cell groups). The ALa was not identified as such in Karten and Hodos (1967) and was first recognized as a projection target of the pallidal part of the basal ganglia by Karten and Dubbeldam (1973). Subsequent studies (Brauth et al., 1978; Medina and Reiner, 1995, 1997; Reiner et al., 1998a), culminating with Jiao et al. (2000), revealed the avian ALa to be a glutamatergic cell group that develops within the same prosencephalic region, is located in the same final adult position as the mammalian subthalamic nucleus, and is reciprocally connected with the pallidal part of the basal ganglia. In terms of its function, the neurotransmitters utilized by its inputs and outputs, its developmental profile, its position in the diencephalon, and its likely presence in reptiles, the ALa clearly appears homologous to the subthalamic nucleus of mammals (Reiner et al., 1998a; Jiao et al., 2000) . For this reason, the Forum concluded that the avian ALa should be renamed the subthalamic nucleus (STN; Table 1, Fig. 3E).

\section{REVISED BASAL TELENCEPHALIC TERMINOLOGY \\ General considerations}

The basal ganglia in mammals forms within a ventral part of the developing telencephalon called the subpallium. The subpallium, which contains the septal nuclei and several other nuclei in addition to those of the basal ganglia, is notably distinct from the overlying telence- 

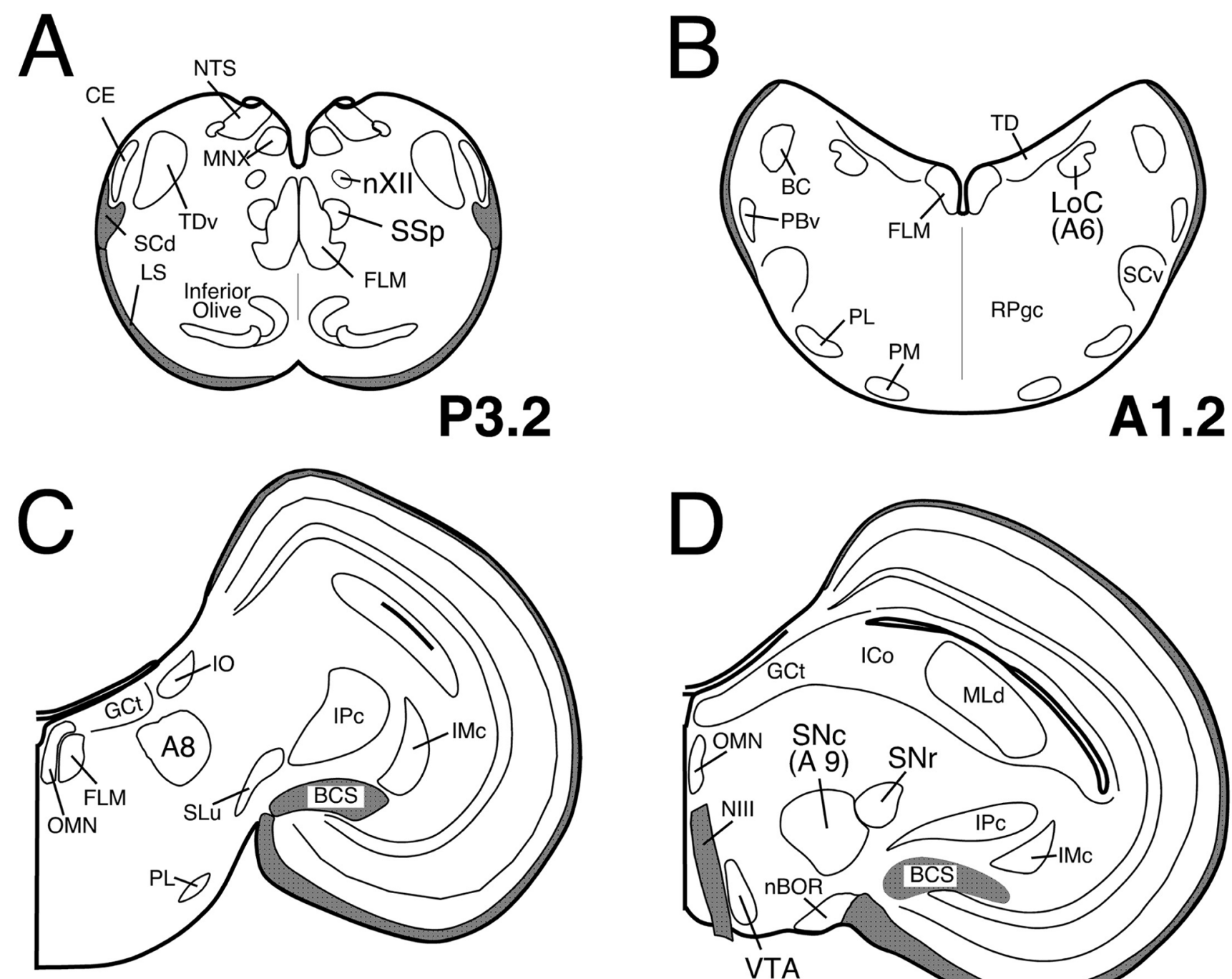

A2.4
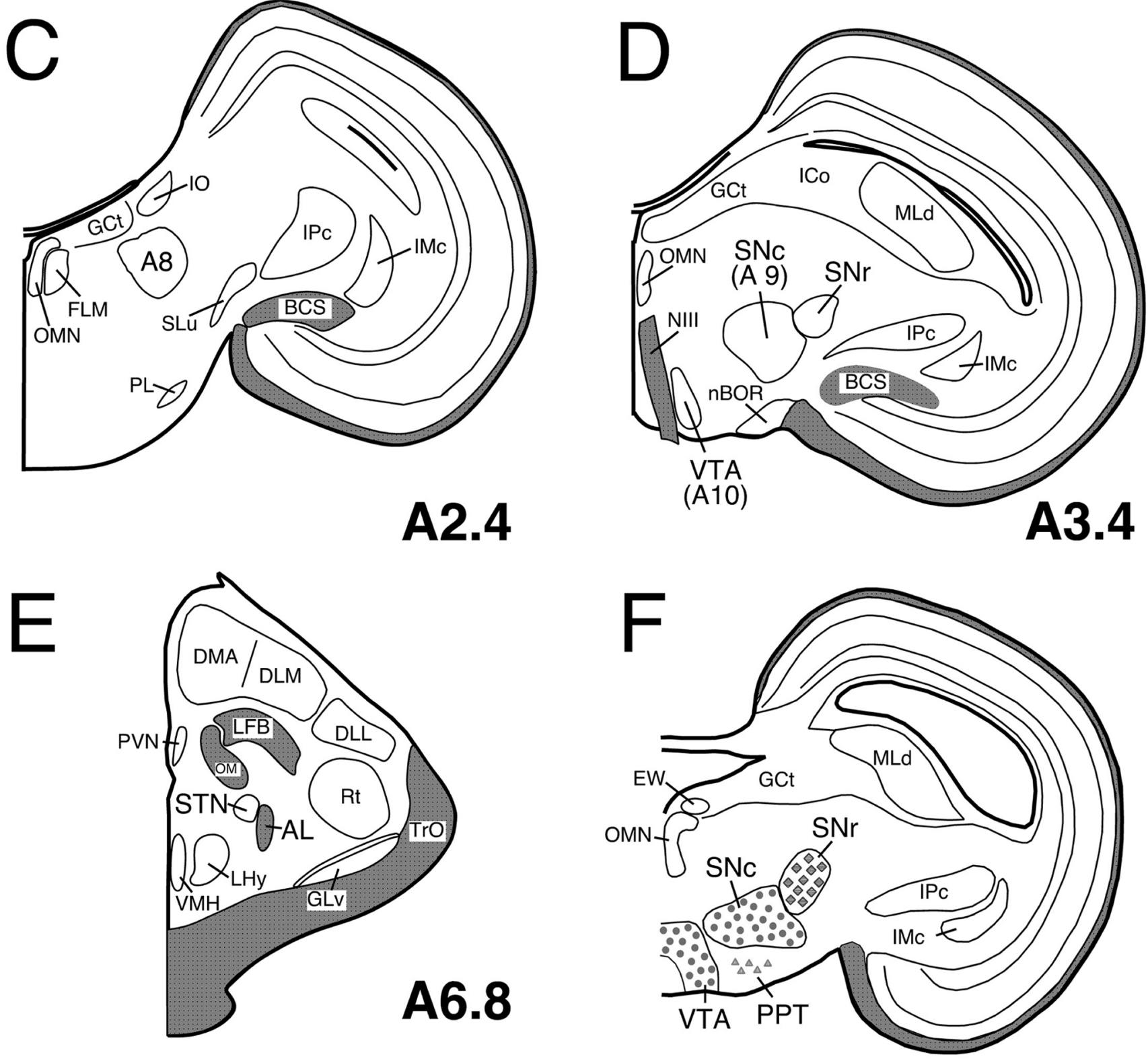

Figure 3 
phalic region called the pallium in its connectivity, neurochemistry, and the genes that regulate its development (Fig. 2B,D-F; Rubenstein et al., 1994; Reiner et al., 1998a; Swanson and Petrovich, 1998). Developmental, topological, neurochemical, cellular, connectional, and functional data all strongly support the conclusion that the subpallial region lateral to the telencephalic ventricle in birds and reptiles contains homologues of mammalian basal ganglia, whereas the subpallial region medial to the lateral ventricle in birds and reptiles contains the homologues of the mammalian septal nuclei (Karten and Dubbeldam, 1973; Brauth and Kitt, 1980; Brauth et al., 1983; Reiner et al., 1984a, 1998a; Smeets, 1994, Medina and Reiner, 1995, 1997; Medina et al., 1997; Smith-Fernandez et al., 1998; Puelles et al., 2000).

Embryological and developmental molecular studies in birds and mammals further indicate that the developing subpallium consists of two radially oriented histogenetic zones, a dorsal one that corresponds to the lateral ganglionic eminence of mammals and a more ventral one that corresponds to the medial ganglionic eminence of mammals (Puelles et al., 2000; Cobos et al., 2001a; Marin and Rubenstein, 2001; Redies et al., 2001). Among the derivatives of the dorsal zone (which expresses $D l \times 1 / 2$ but not Nkx2.1) are the various striatal cell groups, which in mammals make up the dorsal striatum (i.e., the caudate and putamen) and the so-called ventral striatum (the nucleus accumbens and olfactory tubercle). The derivatives of the ventral zone (which expresses $D l x 1 / 2$ and $N k \times 2.1$ ) in mammals include the dorsal pallidum (or globus pallidus) and the ventral pallidum. The dorsal striatal and pallidal cell groups are commonly said to make up the dorsal basal ganglia, or more simply the basal ganglia, whereas the ventral striatal and pallidal cell groups are said to make up the ventral (or limbic) basal ganglia (Heimer et al., $1985,1997)$. These ventral regions differ from the basal ganglia proper in neuropeptide localization, connections, and function.

As with the brainstem, the homology implied by the existing name for a number of cell groups within the subpallium of birds was incorrect or at best obscure, and more recent data had established a consensus as to the correct homologue. The Forum thus sought to rename the various parts of the subpallium in birds to reflect more accurately their homologues in mammals. In particular, we sought to identify and rename the striatal and pallidal subdivisions of the avian dorsal basal ganglia, which as a whole is largely involved in somatomotor functions (Reiner et al., 1994; Doupe and Kuhl, 1999; Jiao et al., 2000), as well as those of the ventral basal ganglia. As in mammals, the striatum and pallidum can be distinguished because their neuron types differ in morphology, neuropeptide content, connections, and electrophysiology (Reiner et al., 1984a, 1998a; Reiner and Anderson, 1990; Medina and Reiner, 1995; Farries and Perkel, 1000). For example, the striatum is rich in dopaminergic fibers and acetylcholinesterase activity, whereas the pallidum is poor in both (Fig. 2B,E). The various subpallial structures, the new terms, and the evidence for homology accepted by the Nomenclature Forum are detailed below on a structure-by-structure basis and summarized in Table 2 . Note that the Forum concluded that sufficient evidence existed to recognize a ventrocaudal part of the subpallium as part of the amygdala, as addressed in the section on the archistriatum.

\section{Rationale for individual changes}

Lobus parolfactorius (LPO) (except its rostral ventromedial part) $\rightarrow$ Medial striatum (MSt). Diverse lines of evidence indicate that the avian LPO has traits characteristic of the dorsal striatum in mammals. These include a prominent dopaminergic input (Fig. 2B) from the substantia nigra pars compacta (SNc/A9) and ventral tegmental area, enrichment in dopamine receptors, a projection back to SNc/A9 and VTA/A10, an acetylcholine-rich (Figs. 2E, 5D) and cholinesterase-rich neuropil, and an enrichment in GABAergic neurons that either contain SP/DYN (Fig. 5A-C) or enkephalin (Lewis et al., 1981; Bottjer, 1993; Casto and Ball, 1994; Grisham and Arnold, 1994; Reiner et al., 1994; Medina and Reiner, 1995; Soha et al., 1996; Reiner et al., 1998a; Luo and Perkel, 1999b; Sun and Reiner, 2000). Additionally, most of the LPO develops from a $D l x 1 / 2$-rich and Nkx2.1-poor neuroepithelium (Fig. 2F), as does the mammalian dorsal striatum
Fig. 3. Line drawings of transverse sections of chicken brain illustrating the locations of several major brainstem cell groups whose names have been revised by the Nomenclature Forum, including the hypoglossal nucleus (nXII) and supraspinal nucleus (SSp) (A), the A6 noradrenergic cell group, which largely overlaps the locus coeruleus (B), the A8 dopaminergic cell group (C), the substantia nigra pars compacta (SNc, the A9 dopaminergic cell group), the ventral tegmental area (VTA, A10 dopaminergic cell group), and the substantia nigra pars reticulata $(\mathrm{SNr})(\mathbf{D})$, and the subthalamic nucleus $(\mathrm{STN})$ of the diencephalon $(\mathbf{E})$. The schematics shown in A-E are all simplified versions of plates from the stereotaxic atlas of the chick brain by Kuenzel and Masson (1988), and numbers to the lower right of each drawing represent the stereotaxic level of that section. The line drawing in $\mathrm{F}$ is of a transverse section from the pigeon midbrain and shows the relative locations of the dopaminergic neurons (filled circles) of the substantia nigra pars compacta and ventral tegmental area, the cholinergic neurons (filled triangles) of the rostroventral part of the pedunculo-pontine tegmental nucleus (PPT), and the GABAergic neurons (filled diamonds) of the substantia nigra pars reticulata. Fiber tracts are shaded gray in the schematics. AL, ansa lenticularis; BC, brachium conjunctivum; BCS, brachium colliculi superioris; $\mathrm{CE}$, nucleus cuneatus externus; DLL, nucleus dorsolateralis anterior, pars lateralis; DLM, nucleus dorsolateralis anterior, pars medialis; DMA, nucleus dorsomedialis anterior; EW, nucleus of Edinger-Westphal; FLM, fasciculus longitudinalis medialis; GCt, griseum centrale; GLv, nucleus geniculatus lateralis, pars ventralis; ICo, nucleus intercollicularis; IMc, nucleus isthmi, pars magnocellularis; IO, nucleus isthmo-opticus; IPc, nucleus isthmi, pars parvocellularis; LFB, lateral forebrain bundle; LHy, lateral hypothalamus; LoC, locus coeruleus; LS, lemniscus spinalis; MLd, nucleus mesencephalicus lateralis, pars dorsalis; MNX, nucleus motorius dorsalis nervi vagi; OM, tractus occipitomesencephalicus; NTS, nucleus tractus solitarii; nBOR, nucleus of the basal optic root; NIII, nervus oculomotorius; nXII, nucleus nervi hypoglossi; OMN, oculomotor nucleus; PBv, nucleus parabrachialis, pars ventralis; PL, nucleus pontis lateralis; PM, nucleus pontis medialis; PPT, pedunculopontine tegmental nucleus; PVN, paraventricular nucleus; RPgc, nucleus reticularis pontis caudalis, pars gigantocellularis; Rt, nucleus rotundus; SCd, tractus spinocerebellaris dorsalis; SCv, nucleus suboeruleus ventralis; SLu, nucleus semilunaris; SSp, nucleus supraspinalis; STN, subthalamic nucleus; TD, nucleus tegmenti dorsalis; TDv, nucleus et tractus descendens nervi trigemini; TrO, tractus opticus; VMH, nucleus ventromedialis hypothalami; VTA, ventral tegmental area. 
A
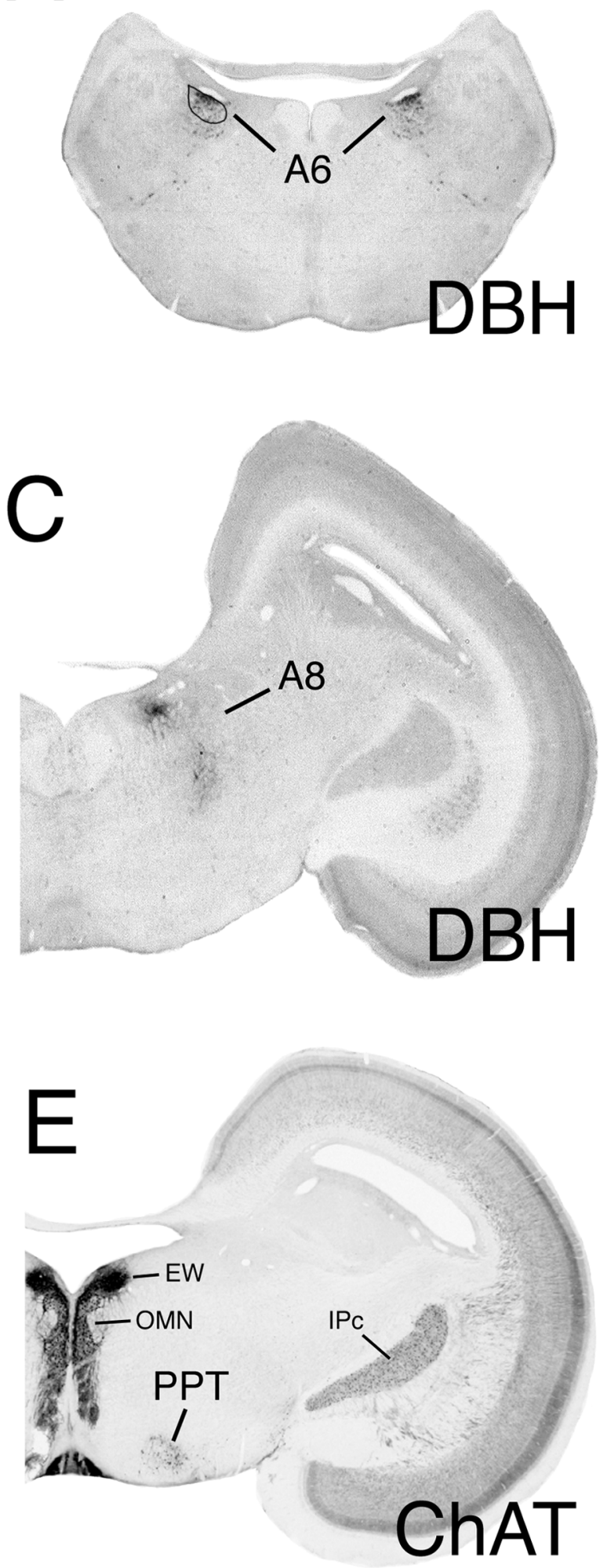

Fig. 4. Images of transverse sections through isthmic (A,B) and mesencephalic $(\mathrm{C}-\mathrm{F})$ levels of pigeon brain, immunolabeled for dopamine $\beta$-hydroxylase (DBH) or tyrosine hydroxylase (TH). A,B: Comparable isthmic-level sections showing that neurons of the locus coeruleus (as delineated in the left half) immunolabel for both DBH and $\mathrm{TH}$, establishing that they are noradrenergic and not dopaminergic. C,D: By contrast, comparable caudal midbrain-level sections show that neurons of A8 immunolabel for TH (D) but not DBH (C), establishing that they are dopaminergic rather than noradrenergic, and thereby supporting the renaming of this region (as delineated in D) to A8, rather than terming it the rostral part of locus coeruleus. Note
B
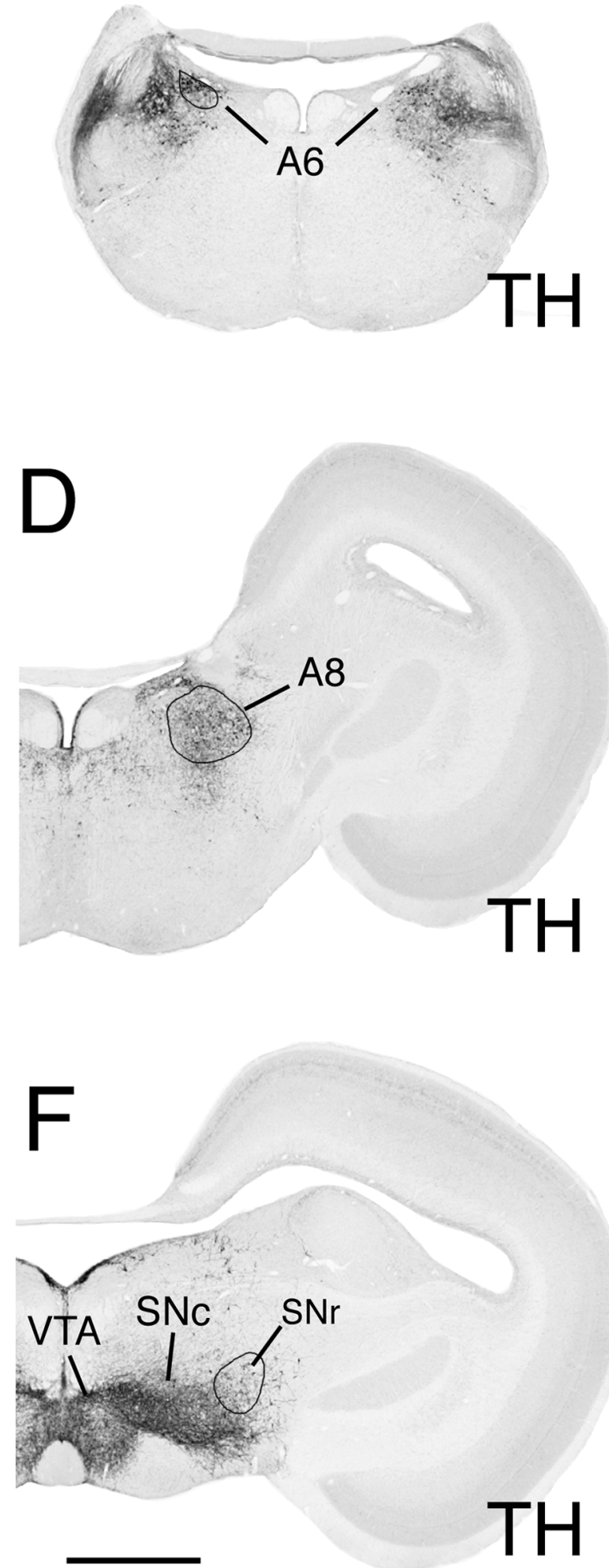

that the labeling ventromedial to the $\mathrm{A} 8$ region in $\mathrm{C}$ represents fiber labeling and not perikaryal labeling, whereas perikaryal labeling above A 8 along the ventricle in D represents the A11 cell group of the central gray (see Fig. 3C). E: Location of the rostroventral part of the cholinergic pedunculo-pontine tegmental (PPT) cell field. F: Location of the TH-containing dopaminergic neurons of the A9 (substantia nigra pars compacta [SNc]) and A10 (ventral tegmental area [VTA]) in the pigeon midbrain. The location of the $\mathrm{SNr}$ with respect to the $\mathrm{SNc}$ is shown here. EW, nucleus of Edinger-Westphal; IPc, nucleus isthmi parvocellularis; OMN, oculomotor nucleus. Scale bar $=2 \mathrm{~mm}$ in $\mathrm{F}$ (applies to A-F). 
(Smith-Fernandez et al., 1998; Puelles et al., 2000). For these reasons, and additional ones summarized in Reiner et al. (1998a), the Forum replaced the arcane name lobus parolfactorius (meaning lobe next to the olfactory bulb) with the term medial striatum and recognized it as (together with the paleostriatum augmentatum) forming the avian dorsal striatum (Table 2, Figs. 5A-F, 6A-D).

This change is attended by several qualifications. First, the medial striatum of birds does not appear to be homologous in a one-to-one fashion (also referred to as discrete homology by Smith, 1967) with the medial part of mammalian dorsal striatum, namely, the caudate nucleus. Principal among the reasons against such a notion is the difference between the LPO and caudate in their projections. In both birds and mammals, the striatum as a whole projects to the substantia nigra and the pallidum, with the projections arising from different populations of mediumsized neurons with heavily spiny dendrites (Gerfen, 1988, Graybiel, 1990; Reiner and Anderson, 1990; Reiner et al., 1998a). In mammals, such striatonigral and striatopallidal neurons are intermingled throughout the caudate and putamen (Beckstead and Cruz, 1986; Reiner and Anderson, 1990; Selemon and Goldman-Rakic, 1990; Reiner et al., 1998a). By contrast, the LPO of birds contains spiny neurons projecting to the substantia nigra but few (if any) that target the pallidal part of the dorsal basal ganglia, whereas the lateral striatum (paleostriatum augmentatum) projects primarily to the dorsal pallidum (Karten and Dubbeldam, 1973; Brauth et al., 1978; Reiner et al., 1983; Bottjer et al., 1989). Thus, wheras the medial striatum in birds (i.e., the LPO) does contain spiny projection neurons, it does not contain all of the same striatal projection neuron types as does the caudate in mammals.

Second, the sparse presence of a pallidal-type neuron projecting to the thalamus may be a unique feature of the avian medial striatum. This cell type was first discovered within a specialized cell group of the medial striatum in male songbirds called Area X (Fig. 6D). Although Area X predominantly contains the cell types typical of the mammalian striatum by physiology, dendritic morphology, and neurotransmitter features (Grisham and Arnold, 1994; Luo and Perkel, 1999b; Farries and Perkel, 2002b), it also contains a cell type that resembles a typical pallidal neuron in its aspiny morphology, its probable input from spiny striatal neurons, its GABAergic inhibitory projection to the thalamus, its neurochemistry, and its electrophysiology (Bottjer et al., 1989; Luo and Perkel, 1999a,b; Farries and Perkel, 2002b; Reiner et al., 2004). Scattered neurons with pallidal-type electrophysiology, connectivity, neurochemistry, and/or morphology have also been observed in the medial striatum proper surrounding Area $\mathrm{X}$ (Iyengar et al., 1999; Farries and Perkel, 2000; Reiner et al., 2004) and in the medial striatum proper of non-vocal learning birds such as chickens (Farries and Perkel, 2002a).

Moreover, some developmental studies have suggested that ventrolateral parts of the chicken medial striatum abutting the pallidum may ontogenetically be a pallidal territory that is heavily invaded by striatal cells during development and thereby becomes predominantly striatal in its cell-type composition (Puelles et al., 2000; Cobos et al., 2001a). If striatal cell-pallidal cell intermingling in part of the medial striatum proves to be a general avian trait that is absent from mammals, it might at that time be advisable to recognize some unique striatopallidal sub- division within the medial striatum and attach to it a specific suitable name. The Forum concluded, however, that insufficient data were available on the location of this region of mixing, on the prevalence of striatal and pallidal cell mixing in medial striatum across avian species, and on its absence from mammals to do so. Additionally, it was clear that what has been called the LPO has predominantly striatal cellular traits (Reiner et al., 1994, 1998a), and so it is appropriate for now to term it simply the medial striatum.

Area $X \rightarrow$ Area $X$. Although Area X of songbirds resides within the avian medial striatum (Nottebohm et al., 1976, Bottjer et al., 1989), its name is unaffected by the change in the name of LPO to medial striatum. Thus, the Forum recommended that Area $\mathrm{X}$ retain its name. A change to nucleus $\mathrm{X}$ was proposed, to reflect the clear boundaries of this structure; after discussion, the Forum took no position on whether Area X should be called nucleus X.

Magnocellular nucleus of LPO $(\mathrm{LPOm}) \rightarrow$ Magnocellular nucleus of medial striatum (MStm). The Forum recognized that the change in the name of the LPO to the medial striatum does affect the name for the part of the budgerigar medial striatum involved in vocal control (Ball, 1994; Striedter, 1994; Durand et al., 1997), because LPO was part of the name for this structure. The Forum recommended that this region henceforth be called the magnocellular nucleus of the medial striatum.

Paleostriatum augmentatum $(P A) \rightarrow$ Lateral striatum (LSt). Diverse lines of evidence indicate that the PA has striatal traits and, together with what has been called the LPO, constitutes the striatal part of avian dorsal basal ganglia (Karten, 1969; Lewis et al., 1981; Bottjer, 1993; Casto and Ball, 1994; Reiner et al., 1994, 1998a; Medina and Reiner, 1995; Soha et al., 1996; Farries and Perkel, 2000; Puelles et al., 2000; Sun and Reiner, 2000). The striatal traits of the PA include a prominent dopaminergic input (Fig. 2B) from the SNc/A9, an enrichment in dopamine receptors, an acetylcholine-rich (Figs. 2E, 5D) and cholinesterase-rich neuropil, an enrichment in GABAergic neurons that contain either SP/DYN (Fig. $5 \mathrm{~A}-\mathrm{C})$ or enkephalin, projections to the paleostriatum primitivum (now to be called the globus pallidus), and a glutamate receptor pattern quite similar to that of the mammalian striatum and avian medial striatum (Wada et al., 2001). Additionally, the PA develops from a $D l x 1 / 2$ rich and Nkx2.1-poor neuroepithelium (Fig. 2F; SmithFernandez et al., 1998; Puelles et al., 2000).

For these reasons, as well as reasons summarized in Reiner et al. (1998a), the Forum concluded that the name paleostriatum augmentatum (with its inaccurate evolutionary and cellular implications of being a pallidal derivative) should be abandoned and replaced with the term lateral striatum (Table 2, Figs. 5A-F, 6A-C). As for the avian medial striatum compared with the mammalian caudate nucleus, there is no compelling evidence that the lateral striatum of birds is homologous in a one-to-one fashion with the lateral part of the mammalian striatum, namely, the putamen. For example, the LSt in birds contains spiny neurons that mainly project to the pallidal part of basal ganglia but not to the substantia nigra (Karten and Dubbeldam, 1973; Anderson and Reiner, 1991a; Veenman et al., 1995a; Medina et al., 1997; Mezey and Csillag, 2002), whereas striatonigral and striatopallidal neurons are intermingled throughout the putamen 
TABLE 2. New Terminology for Subpallial Cell Groups

\begin{tabular}{|c|c|c|c|c|}
\hline $\begin{array}{l}\text { Structure and Karten-Hodos (or } \\
\text { other) term for structure } \\
\text { (abbreviation) }\end{array}$ & $\begin{array}{l}\text { Latin name adopted } \\
\text { by Forum } \\
\text { (abbreviation) }\end{array}$ & $\begin{array}{l}\text { English name } \\
\text { adopted by Forum } \\
\text { (abbreviation) }\end{array}$ & Comments & $\begin{array}{l}\text { Refs. pertinent to the } \\
\text { new name }\end{array}$ \\
\hline $\begin{array}{l}\text { Lobus parolfactorius (excluding its rostral } \\
\text { ventromedial part) (LPO, excluding its } \\
\text { rostral ventromedial part) }\end{array}$ & Striatum mediale (StM) & Medial striatum (MSt) & $\begin{array}{l}\text { English term more commonly } \\
\text { used than Latin term }\end{array}$ & $\begin{array}{l}\text { Reiner et al., 1998a } \\
\text { Puelles et al., } 2000\end{array}$ \\
\hline $\begin{array}{l}\text { Area X within male songbird LPO first } \\
\text { named by Nottebohm et al., } 1976(X)\end{array}$ & Area $\mathrm{X}(\mathrm{X})$ & Area $\mathrm{X}(\mathrm{X})$ & $\begin{array}{l}\text { Continued use of the } \\
\text { entrenched term Area X } \\
\text { recommended by Forum }\end{array}$ & $\begin{array}{l}\text { Nottebohm et al., } 1976 \\
\text { Bottjer et al., } 1989\end{array}$ \\
\hline $\begin{array}{l}\text { Vocal control region in parrot LPO } \\
\text { termed magnocellular nucleus of LPO } \\
\text { (LPOm) }\end{array}$ & $\begin{array}{l}\text { Striatum mediale, pars } \\
\text { magnocellularis } \\
(\mathrm{StMm})\end{array}$ & $\begin{array}{l}\text { Magnocellular part of } \\
\text { medial striatum } \\
\text { (MStm) }\end{array}$ & $\begin{array}{l}\text { Comparable to Area X but } \\
\text { likely to be independently } \\
\text { evolved }\end{array}$ & $\begin{array}{l}\text { Ball, } 1994 \\
\text { Striedter, } 1994 \\
\text { Durand et al., } 1997\end{array}$ \\
\hline Paleostriatum augmentatum (PA) & Striatum laterale (StL) & Lateral striatum (LSt) & $\begin{array}{l}\text { English term more commonly } \\
\text { used than Latin term }\end{array}$ & $\begin{array}{l}\text { Reiner et al., } 1998 \mathrm{a} \\
\text { Puelles et al., } 2000\end{array}$ \\
\hline Paleostriatum primitivum $(\mathrm{PP})$ & Globus pallidus (GP) & Globus pallidus (GP) & $\begin{array}{l}\text { Use of globus pallidus for } \\
\text { birds emphasizes homology } \\
\text { to mammalian GP }\end{array}$ & $\begin{array}{l}\text { Karten and Dubbeldam, } 1973 \\
\text { Medina and Reiner, } 1997 \\
\text { Reiner et al., 1998a } \\
\text { Puelles et al., 2000 }\end{array}$ \\
\hline Nucleus intrapeduncularis (INP) & $\begin{array}{l}\text { Nucleus } \\
\text { intrapeduncularis } \\
\text { (INP) }\end{array}$ & $\begin{array}{c}\text { Intrapeduncular } \\
\text { nucleus (INP) }\end{array}$ & $\begin{array}{l}\text { Subpallial region unique to } \\
\text { birds and has largely } \\
\text { striatal traits }\end{array}$ & $\begin{array}{l}\text { Karten and Dubbeldam, } 1973 \\
\text { Reiner et al., } 1984 \\
\text { Reiner et al., 1998b }\end{array}$ \\
\hline $\begin{array}{l}\text { Ventromedial part of rostral lobus } \\
\text { parolfactorius (no abbreviation since } \\
\text { not recognized as a distinct region) }\end{array}$ & Nucleus accumbens (Ac) & $\begin{array}{l}\text { Nucleus accumbens } \\
\text { (Ac) }\end{array}$ & $\begin{array}{l}\text { Precise borders remain } \\
\text { undefined }\end{array}$ & $\begin{array}{l}\text { Reiner et al., } 1983 \\
\text { Berk, } 1987 \\
\text { Veenman et al., } 1995 \\
\text { Mezey and Csillag, } 2002\end{array}$ \\
\hline Tuberculum olfactorium (TO) & $\begin{array}{l}\text { Tuberculum olfactorium } \\
\text { (TuO) }\end{array}$ & $\begin{array}{l}\text { Olfactory tubercle } \\
\quad(\mathrm{OTu})\end{array}$ & $\begin{array}{c}\text { Homologous to structure of } \\
\text { same name in mammals }\end{array}$ & $\begin{array}{l}\text { Reiner and Karten, } 1985 \\
\text { Reiner et al., } 1998 \mathrm{a} \\
\text { Roberts et al., } 2002\end{array}$ \\
\hline $\begin{array}{l}\text { Unnamed region in Karten and Hodos } \\
\text { between LPO and quintofrontal tract } \\
\text { now known to contain MFB [FPM }]^{2} \text { and } \\
\text { field of GABAergic neurons; referred to } \\
\text { as ventral paleostriatum (VP or PVt) by } \\
\text { others. }\end{array}$ & Pallidum ventrale $(\mathrm{PVt})$ & Ventral pallidum (VP) & $\begin{array}{l}\text { Large scattered GABAergic } \\
\text { neurons in MFB (FPM) } \\
\text { homologous to mammalian } \\
\text { cell group of same name }\end{array}$ & $\begin{array}{l}\text { Kitt and Brauth, } 1981 \\
\text { Reiner et al., } 1984 \\
\text { Veenman and Reiner, } 1994 \\
\text { Medina and Reiner, } 1997 \\
\text { Kuenzel and Masson, } 1988\end{array}$ \\
\hline Nucleus accumbens (Ac) & $\begin{array}{l}\text { Nucleus striae terminalis } \\
\text { lateralis (NSTL) }\end{array}$ & $\begin{array}{l}\text { Lateral part of the } \\
\text { bed nucleus of the } \\
\text { stria terminalis } \\
\text { (BSTL) }\end{array}$ & $\begin{array}{l}\text { Erroneously identified as } \\
\text { nucleus accumbens in } \\
\text { Karten and Hodos }\end{array}$ & $\begin{array}{l}\text { Berk, } 1987 \\
\text { Reiner et al., } 1994 \\
\text { Aste et al., } 1998\end{array}$ \\
\hline $\begin{array}{l}\text { Unnamed region around the lateral edge } \\
\text { of the anterior commissure (no name } \\
\text { assigned in Karten and Hodos, 1967) }\end{array}$ & $\begin{array}{l}\text { Nucleus striae terminalis } \\
\text { medialis (NSTM) }\end{array}$ & $\begin{array}{l}\text { Medial part of the bed } \\
\text { nucleus of the stria } \\
\text { terminalis (BSTM) }\end{array}$ & $\begin{array}{l}\text { Homology to mammalian cell } \\
\text { group of same name } \\
\text { supported by } \\
\text { neurochemical, hodological, } \\
\text { and functional similarity }\end{array}$ & $\begin{array}{l}\text { Aste et al., } 1998 \\
\text { Jurkevic et al., } 1999\end{array}$ \\
\hline $\begin{array}{l}\text { Region encompassing FPL and unnamed } \\
\text { region between LPO and QF (no name } \\
\text { assigned in Karten and Hodos, } 1967 \text { for } \\
\text { cholinergic neurons in LFB and MFB) }\end{array}$ & $\begin{array}{l}\text { Nucleus basalis } \\
\text { magnocellularis (NBM) }\end{array}$ & $\begin{array}{l}\text { Basal magnocellular } \\
\text { cholinergic nucleus } \\
\text { (NBM) }\end{array}$ & $\begin{array}{l}\text { Large cholinergic neurons } \\
\text { scattered in } \mathrm{LFB}^{3} \text { and } \\
\text { MFB }^{2} \text { overlaps ventral } \\
\text { pallidum }\end{array}$ & $\begin{array}{l}\text { Mesulam et al., } 1984 \\
\text { Woolf, } 1991 \\
\text { Medina and Reiner, } 1994\end{array}$ \\
\hline $\begin{array}{l}\text { Region of fasciculus of diagonal band } \\
\text { (FDB) }\end{array}$ & $\begin{array}{l}\text { Nucleus diagonalis } \\
\text { Brocae (NDB) }\end{array}$ & $\begin{array}{l}\text { Nucleus of the } \\
\text { diagonal band } \\
\text { (NDB) }\end{array}$ & $\begin{array}{l}\text { Cholinergic neurons in and } \\
\text { around FDB }\end{array}$ & $\begin{array}{l}\text { Mesulam et al., } 1984 \\
\text { Woolf, } 1991 \\
\text { Medina and Reiner, } 1994\end{array}$ \\
\hline Nucleus septalis medialis (SM) & $\begin{array}{l}\text { Nucleus septalis medialis } \\
\text { (SM) }\end{array}$ & $\begin{array}{l}\text { Medial septal nucleus } \\
\quad(\text { SM) }\end{array}$ & $\begin{array}{l}\text { Homologous to mammalian } \\
\text { cell group of same name }\end{array}$ & $\begin{array}{l}\text { Mesulam et al., } 1984 \\
\text { Woolf, } 1991 \\
\text { Medina and Reiner, } 1994\end{array}$ \\
\hline Nucleus septalis lateralis (SL) & $\begin{array}{l}\text { Nucleus septalis lateralis } \\
\text { (SL) }\end{array}$ & $\begin{array}{l}\text { Lateral septal nucleus } \\
\text { (SL) }\end{array}$ & $\begin{array}{l}\text { Homologous to mammalian } \\
\text { cell group of same name }\end{array}$ & $\begin{array}{l}\text { Reiner et al., } 1994 \\
\text { Smeets and Reiner, } 1994\end{array}$ \\
\hline
\end{tabular}

${ }^{1}$ Summary of the nomenclature recommendations of the Forum for the various subpallial telencephalic structures in birds, beginning with structures of the basal ganglia and proceeding largely in a superior to inferior order. For each structure considered, the first column of the table shows the original name assigned (typically from Karten and Hodos, 1967) and the original abbreviation, the next column shows the Latin variant and abbreviation of the new (or carried over) term recommended by the Forum, the next shows the English variant and abbreviation of the new (or carried over) recommended term, and the final two columns present any noteworthy comments about the change and key references pertinent to the change.

${ }^{2}$ MFB (FPM), medial forebrain bundle (fasciculus prosencephali medialis).

${ }^{3} \mathrm{LFB}$ (FPL), lateral forebrain bundle (fasciculus prosencephali lateralis).

(Beckstead and Cruz, 1986; Reiner and Anderson, 1990; Selemon and Goldman-Rakic, 1990; Reiner et al., 1998a).

Paleostriatum primitivum (PP) $\rightarrow$ Globus pallidus (GP). The Forum recommended that the paleostriatum primitivum henceforth be called the globus pallidus (Table 2, Figs. 5A-F, 6B,C). This term is appropriate for descriptive reasons (both avian GP and its mammalian counterpart are pale) and because of neurochemical, cellular, hodological, phylogenetic, and developmental evidence that the avian GP is homologous to the mammalian GP (Karten and Dubbeldam, 1973; Brauth et al., 1978; Kitt and Brauth, 1981; Reiner et al., 1984a, 1998a; Reiner and Carraway, 1987; Veenman and Reiner, 1994; Medina and Reiner, 1995, 1997; Medina et al., 1997; Marin et al., 1998; Puelles et al., 2000; Cobos et al., 2001a; Gonzalez et al., 2002; Brox et al., 2003). In both birds and mammals, the projection neurons of the globus pallidus possess large cell bodies and smooth dendrites, derive from an Nkx2.1+ neuroepithelium, and give rise to the motor output projections of the basal ganglia. Additionally, globus pallidus neurons in both birds and mammals are GABAergic, contain the neuropeptide LANT6 (Fig. 5E), and receive inputs with a woolly fiber morphology from either SP/DYNcontaining (Fig. 5A-C) or ENK-containing striatal neurons, as well as a glutamatergic input from the subthalamic nucleus (Reiner et al., 1998a, 1999; Jiao et al., 2000). In addition, functional evidence points to similarities in electrophysiological properties (Farries and Perkel, 2000). Avian globus pallidus neurons, however, appear to migrate farther laterally than do mammalian pallidal neurons (Puelles et al., 2000; Cobos et al., 2001a). Although the avian globus pallidus as a field is not as globular as the 
mammalian GP, even different mammalian species show variation in the shape of the GP, and the advantages of using globus pallidus as the new name for the PP in birds outweighs any slightly misleading implication as to its shape.

Intrapeduncular nucleus $($ INP) $\rightarrow$ Intrapeduncular nucleus (INP). This enigmatic cell group is located within the lateral forebrain bundle below the inferior margin of the avian globus pallidus and is named for its location within the peduncle (i.e., forebrain bundle). Although Karten and Dubbeldam (1973) thought that its position resembled that of the mammalian internal pallidal segment, subsequent immunolabeling studies showed that it lacked the pallidal-type neurons and the SP/DYNcontaining striatal input characteristic of the internal pallidal segment (Reiner et al., 1983; Reiner and Carraway, 1987; Anderson and Reiner, 1990; Veenman and Reiner, 1994). More recent studies have shown that the INP contains spiny neurons that express DARPP32, a striatal characteristic (Schnabel et al., 1997; Reiner et al., 1998b), a very similar glutamate receptor profile to the striatum (Wada et al., 2001), and numerous cholinergic neurons (Medina and Reiner, 1994), which is characteristic of, but not unique to, the striatum. Moreover, the INP has recently been found to develop within the striatal sector of the subpallium, to show continuity with the medial striatum, and to contain neurons expressing cell-surface proteins characteristic of striatal neurons (Medina et al., 2002). Although the data are thus beginning to suggest a largely striatal nature for the INP, the Forum concluded that it was still premature to conclude unequivocally that the INP is a striatal territory. Thus, the Forum decided to leave the name for the INP unaltered (Table 2, Figs. 5D, $6 \mathrm{~B})$.

Ventromedial rostral $\mathrm{LPO} \rightarrow$ Nucleus accumbens (Ac). In the Karten and Hodos atlas, a region at the ventral tip of the lateral ventricle extending several millimeters rostral from the level of the anterior commissure, noticeably associated with a small bulge into the lateral ventricle, is identified as the nucleus accumbens. Other brain atlases of birds have followed this practice (Stokes et al., 1974; Youngren and Phillips, 1983; Kuenzel and Masson, 1988). As discussed in detail below, this region in actuality appears to be homologous to the lateral part of the mammalian bed nucleus of the stria terminalis. The nucleus accumbens in mammals is a ventral striatal territory that surrounds the inferior margin of the lateral ventricle at levels well anterior to the anterior commissure and is cytoarchitectonically continuous with the overlying caudatoputamen (i.e., the dorsal striatum) and with the olfactory tubercle below it (Heimer et al., 1985, 1997).

Although the hodological and neurochemical traits of mammalian nucleus accumbens grade into those of the overlying caudatoputamen, the accumbens and olfactory tubercle do differ from the dorsal striatum (Heimer et al., 1985, 1997). In particular, the accumbens is distinguished by its preferential reciprocal connections with the ventral tegmental area and its afferent input from limbic pallial regions such as the hippocampal complex, amygdala, and cingulate cortex, as well as from the frontal neocortex (Heimer et al., 1985, 1997; Paxinos and Watson, 1998). By contrast, the caudatoputamen has preferential reciprocal connections with the substantia nigra and receives its major pallial inputs from the neocortex (Heimer et al., 1985, 1997). By its cellular neurochemistry, the ventral striatum (including nucleus accumbens) also differs from the caudatoputamen. For example, spiny projection neurons of the caudate and putamen contain either enkephalin or both SP and DYN, but rarely co-contain SP and enkephalin (Anderson and Reiner, 1990; Besson et al., 1990; Reiner and Anderson, 1990; Lee et al., 1997). By contrast, SP co-localization with enkephalin in spiny projection neurons is much more common in the ventral striatum, including the nucleus accumbens (Anderson and Reiner, 1990; Furuta et al., 2002).

The region surrounding the tip of the lateral ventricle, at the ventromedial margin of the rostral pole of what has been called the LPO in birds, possesses the same topographic, hodological, and neurochemical traits as the nucleus accumbens of mammals (Brauth et al., 1978; Anderson and Reiner, 1990, 1991a; Reiner and Anderson, 1990; Veenman et al., 1995a; Mezey and Csillag, 2002; Roberts et al., 2002). By contrast, much of the remainder of what has been called the LPO is reciprocally connected with the substantia nigra pars compacta, receives pallial input from somatosensory and somatomotor areas of the pallium, and shows little co-localization of SP and enkephalin in spiny striatal projection neurons (Brauth et al., 1978; Reiner et al., 1983, 1984a,b; Anderson and Reiner, 1990, 1991b; Reiner and Anderson, 1990; Veenman et al., 1995b; Mezey and Csillag, 2002; Roberts et al., 2002). Thus, the region at the rostral ventromedial tip of medial striatum in birds is comparable to the mammalian nucleus accumbens. Moreover, a topographically, hodologically, and neurochemically similar cell group has been identified as the nucleus accumbens in turtles, lizards, and snakes (Russchen et al., 1987; Russchen and Jonker, 1988; Anderson and Reiner, 1990; Reiner and Anderson, 1990; Smeets, 1994; Guirado et al., 1999; Smeets et al., 2001).

For these reasons, the Forum recognized and recommended that the rostral ventromedial part of the former LPO of birds be called the nucleus accumbens and that the term medial striatum only be used to refer to the remainder of the LPO (Table 2, Fig. 6A,D). As in mammals, however, a precise cytoarchitectonic border between the dorsal striatum and nucleus accumbens is not evident, and a neurochemical criterion by which to distinguish the two fields unambiguously has not been identified. The finding that the medialmost sector of the medial striatum is reciprocally connected with the VTA and receives limbic pallial input (Veenman et al., 1995a; Mezey and Csillag, 2002) raises the possibility that the avian accumbens might extend more dorsally than shown in our figures (Fig. 6A,D). Additionally, whereas the nucleus accumbens of mammals possesses core and shell subdivisions, comparable subdivisions of the nucleus accumbens in birds have not been conclusively identified (Heimer et al., 1997; Roberts et al., 2002).

Tuberculum olfactorium (TO) $\rightarrow$ Tuberculum olfactorium (TuO). The olfactory tubercle is a telencephalic territory at the lower edge of the subpallium that was recognized in pigeons by Karten and Hodos (1973) and by most subsequent published papers or atlases dealing with the telencephalon in birds (Stokes et al., 1974; Youngren and Phillips, 1983; Kuenzel and Masson, 1988; Matochik et al., 1991). It is now established that, as in mammals, this cell group is a ventral striatal region that receives olfactory bulb input and resembles the olfactory tubercle of mammals in its neurochemistry and connectivity (Heimer et al., 1985, 1997; Reiner and Karten, 1985; Reiner et 

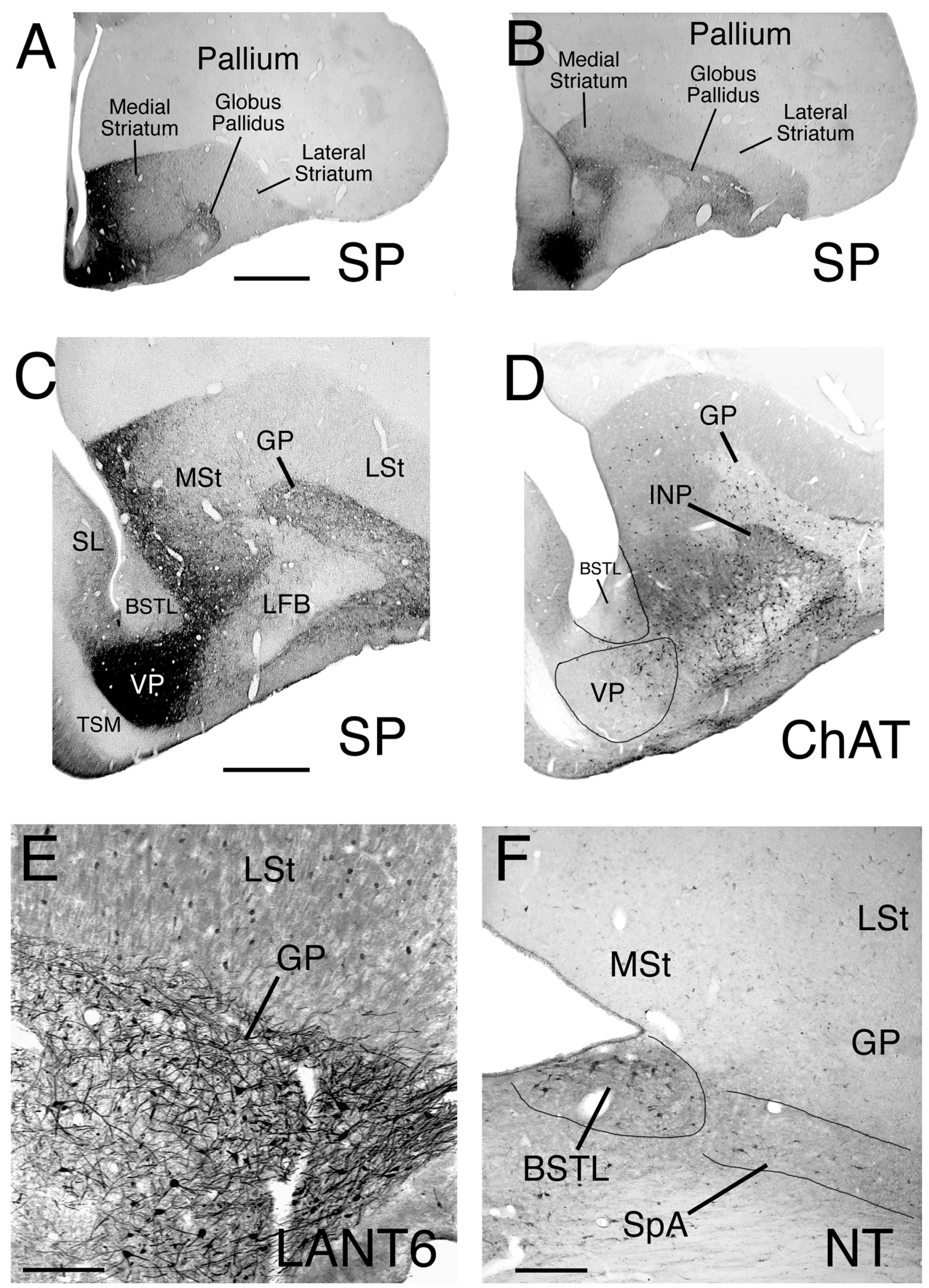
al., 1994, 1998a; Roberts et al., 2002). The Forum thus endorsed the previously recognized homology of this cell group to the similarly named mammalian cell group and recommended no name change (Table 2, Figs. 6A,D, 8B). The Forum recommends a slight modification of the abbreviation for the olfactory tubercle (i.e., $\mathrm{TuO}$ ) so it is not in conflict with the common abbreviation for the optic tract (i.e., TO).

Undefined GABAergic cell group within medial forebrain bundle in Karten and Hodos (identified as the ventral paleostriatum in some studies) $\rightarrow$ Ventral pallidum (VP). A group of GABAergic neurons within the medial forebrain bundle (also called the fasciculus prosencephali medialis [FPM]) has been demonstrated in birds (Veenman and Reiner, 1994). This cell group is pallidal in nature because its glutamate receptor expression profile is identical to that of the GP (Wada et al., 2001) and because its neurons arise from the same Nkx2.1-expressing histogenetic subpallial neuroepithelial domain as the GP (Puelles et al., 2000). Additionally, it has the cellular neurochemistry, receives the ventral striatal inputs, and has the outputs characteristic of the ventral pallidum of mammals (Kitt and Brauth, 1981; Reiner and Carraway, 1987; Reiner and Anderson, 1990; Veenman and Reiner, 1994; Medina and Reiner, 1997; Reiner et al., 1998a; Roberts et al., 2002). A comparable cell group is present in turtles, crocodilians, and lizards (Brauth and Kitt, 1980; Brauth, 1984; Reiner, 1987; Reiner and Carraway, 1987; Russchen et al., 1987; Russchen and Jonker, 1988). The Forum thus recognized this cell group, which has sometimes been called the ventral paleostriatum (Kuenzel and Masson, 1988), and recommended it be referred to as the ventral pallidum (Table 2, Figs. 5C,D, 6B). The word ventral is used because this provides the VP with a name that

Fig. 5. Images of transverse sections of pigeon brain immunolabeled for various markers to show the location of several subpallial cell groups affected by the nomenclature revision. A,B: Rostral telencephalic level and mid-telencephalic level (respectively) of pigeon brain at low power, immunolabeled for substance P (SP). These images (adapted from Reiner et al., 1998b) show that SP enrichment in the subpallium can serve as a marker to distinguish the subpallium from the pallium, and moreover distinguish different subdivisions within the subpallium (note C). C,D: Higher power views of the subpallium at a mid-telencephalic level immunolabeled (respectively) for SP and choline acetyltransferase (ChAT). Note the enrichment of the ventral pallidum in SP+ fibers and ChAT + neurons and the paucity of $\mathrm{SP}+$ fibers and relative paucity of ChAT + neurons in the lateral part of the bed nucleus of the stria teriminalis (BSTL). In D, the field of cholinergic neurons spanning the VP and LFB represents the basal magnocellular cholinergic cell group (NBM). E,F: Highpower views of the globus pallidus (GP) immunolabeled for the pallidal neuron marker LANT6 (E, adapted from Reiner and Carraway, 1987), and the BSTL and its continuation into the subpallial amygdala (SpA) immunolabeled for neurotensin (F). Pallidal neurons and their dendrites characteristically contain the neurotensin-related hexapeptide LANT6, which thereby serves to identify the pallidal portions of the subpallium (E). LANT6 + neurons in the lateral striatum in E represent parvalbuminergic interneurons, which co-contain LANT6 (Reiner et al., 1998a). The BSTL is distinguished by a cluster of neurotensin-containing neurons, whereas the SpA is distinguished by sparsely distributed neurotensin-containing neurons $(\mathrm{F})$. Other abbreviations: GP, globus pallidus; INP, intrapeduncular nucleus; LFB, lateral forebrain bundle; LSt, lateral striatum; MSt, medial striatum; SL, lateral septal nucleus; TSM, tractus septopallio-mesencephalicus; VP, ventral pallidum. Scale bar $=2 \mathrm{~mm}$ in A (applies to $\mathrm{A}, \mathrm{B}$ ); $1 \mathrm{~mm}$ in $\mathrm{C}$ (applies to $\mathrm{C}, \mathrm{D}$ ); $200 \mu \mathrm{m}$ in $\mathrm{E} ; 250 \mu \mathrm{m}$ in $\mathrm{F}$. is positionally appropriate with respect to its more dorsal counterpart, the GP, which has also been termed the dorsal pallidum.

Nucleus accumbens $(A c) \rightarrow$ Bed nucleus of the stria terminalis, lateral part (BSTL). The region identified as the nucleus accumbens by Karten and Hodos (1967) does not correspond to the nucleus accumbens of mammals, as was noted above, because it lacks the neurochemistry and cell types characteristic of the mammalian nucleus accumbens (Reiner et al., 1983, 1984a,b; Berk, 1987; Aste et al., 1998a,b). Instead, the Forum concluded that the area identified as the nucleus accumbens in Karten and Hodos is homologous to the lateral part of the mammalian bed nucleus of the stria terminalis, based on neurochemical and hodological evidence summarized by Aste et al. (1998a,b). The BSTL in birds has a rostral extension that tapers as it reaches the frontal pole of the medial striatum. This extension occupies a small but conspicuous bulge into the lateral edge of the inferior aspect of the telencephalic ventricle, and it may be surrounded by the true nucleus accumbens at very rostral levels (Reiner et al., 1983, 1984b; Aste et al., 1998a,b). The Forum thus recommended that the term nucleus accumbens be discontinued as the name for the region identified as accumbens in Karten and Hodos (1967) and that the lateral part of the bed nucleus of the stria terminalis be employed instead (Table 2, Figs. 5C,D,F, 6B,C). Note that the name for the BSTL in mammals (as well as that for the medial part of the bed nucleus of the stria terminalis) derives from the fact that it is embedded in a part of the stria terminalis (the dorsal part) and is thus a major target of this fiber bundle (De Olmos and Ingram, 1972). The stria terminalis in mammals has separate components that arise from diverse amygdaloid structures (Krettek and Price, 1977; Swanson and Petrovich, 1998), and the main fiber bundle itself courses from the amygdala toward the lateral edge of the anterior commissure, before ramifying into its ascending, commissural, and descending components (De Olmos and Ingram, 1972). Adopting the term BSTL for birds implies that a stria terminalis exists in birds and has the BSTL as one of its targets. The stria terminalis in birds appears to be at least partly represented by the hypothalamic part of the occipitomesencephalic tract, which courses medially from the archistriatum and taenia toward the lateral edge of the anterior commissure, before dividing into components that distribute to the BSTL and components that descend to the hypothalamus (Zeier and Karten, 1971).

Region around lateral edge of anterior commissure without a formal name $\rightarrow$ Bed nucleus of the stria terminalis, medial part (BSTM). The cell group located around the anterior commissure at the subpalliopreoptic transition in birds corresponds to the medial part of the mammalian bed nucleus of the stria terminalis, based on numerous topographic, hodological, and neurochemical criteria (Berk, 1987; Aste et al., 1998a,b; Jurkevich et al., 1999). This region in birds lies within the path of the apparent avian counterpart of the stria terminalis (Zeier and Karten, 1971). The Forum thus recommended that the term medial part of the bed nucleus of the stria terminalis be employed for this region in birds (Table 2, Fig. 6C). By in situ hybridization histochemistry and immunocytochemistry for arginine vasotocin, a single BSTM nucleus has been identified in Japanese quail (Aste et al., 1998a,b), whereas two BSTM subnuclei have been identi- 
A

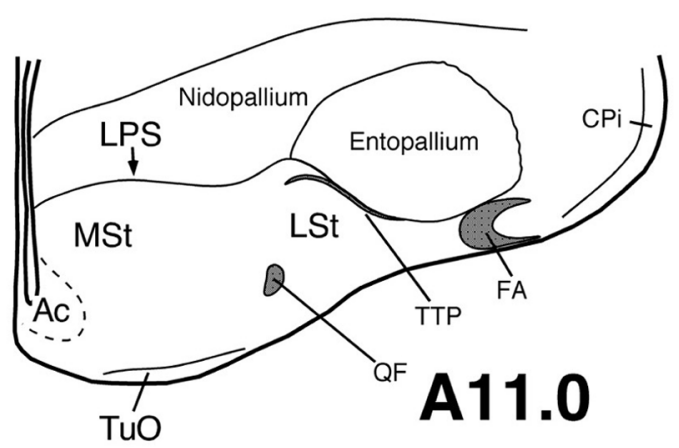

C

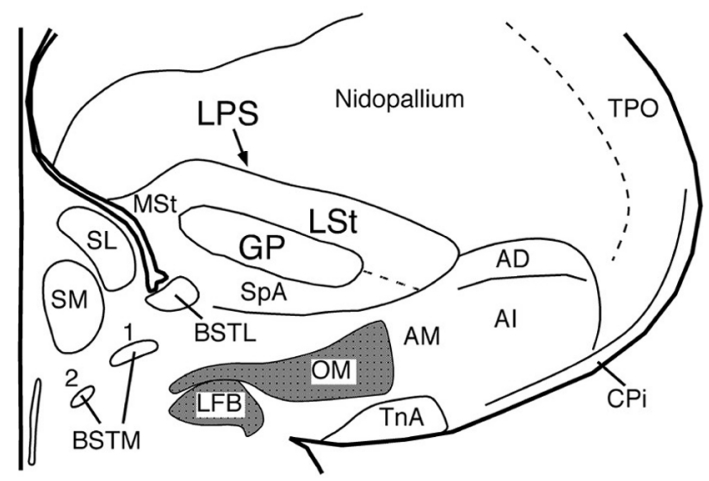

A8.0

Fig. 6. Line drawings of a rostral to caudal series of transverse sections of chicken brain illustrating the locations of the major subpallial cell groups whose names have been revised by the Nomenclature Forum (A-C), and a line drawing of a transverse section of male zebra finch telencephalon showing the location of Area $\mathrm{X}$ within the basal ganglia (D). The schematics shown in A-C are all simplified versions of plates from the stereotaxic atlas of chick brain by Kuenzel and Masson (1988), and numbers to the lower right of each drawing represent the stereotaxic level of that section. Fiber tracts are shaded gray in the schematics. AA, arcopallium anterius; Ac, nucleus accumbens; $\mathrm{AD}$, arcopallium dorsale; $\mathrm{AI}$, arcopallium intermedium; $\mathrm{AM}$, arcopallium mediale; BSTL, lateral part of bed nucleus of stria ter-

fied in chickens (Jurkevich et al., 1999). In chicken, the two BSTM subnuclei can be given the abbreviations BSTM1 and BSTM2, with formal names that follow suit. The BSTM in quail corresponds to the BSTM1 in chickens. It is important to note that the medial BST nuclei have been shown to be sexually dimorphic in chicken and quail and thus may be so in other avian species as well.

Undefined cholinergic cell group within $\mathrm{MFB} \rightarrow \mathrm{Nu}$ cleus basalis magnocellularis (NBM). A field of large cholinergic neurons invests the lateral and medial forebrain bundles, the globus pallidus and ventral pallidum in birds (Medina and Reiner, 1994). This field is comparable to the field of large cholinergic neurons that spans the
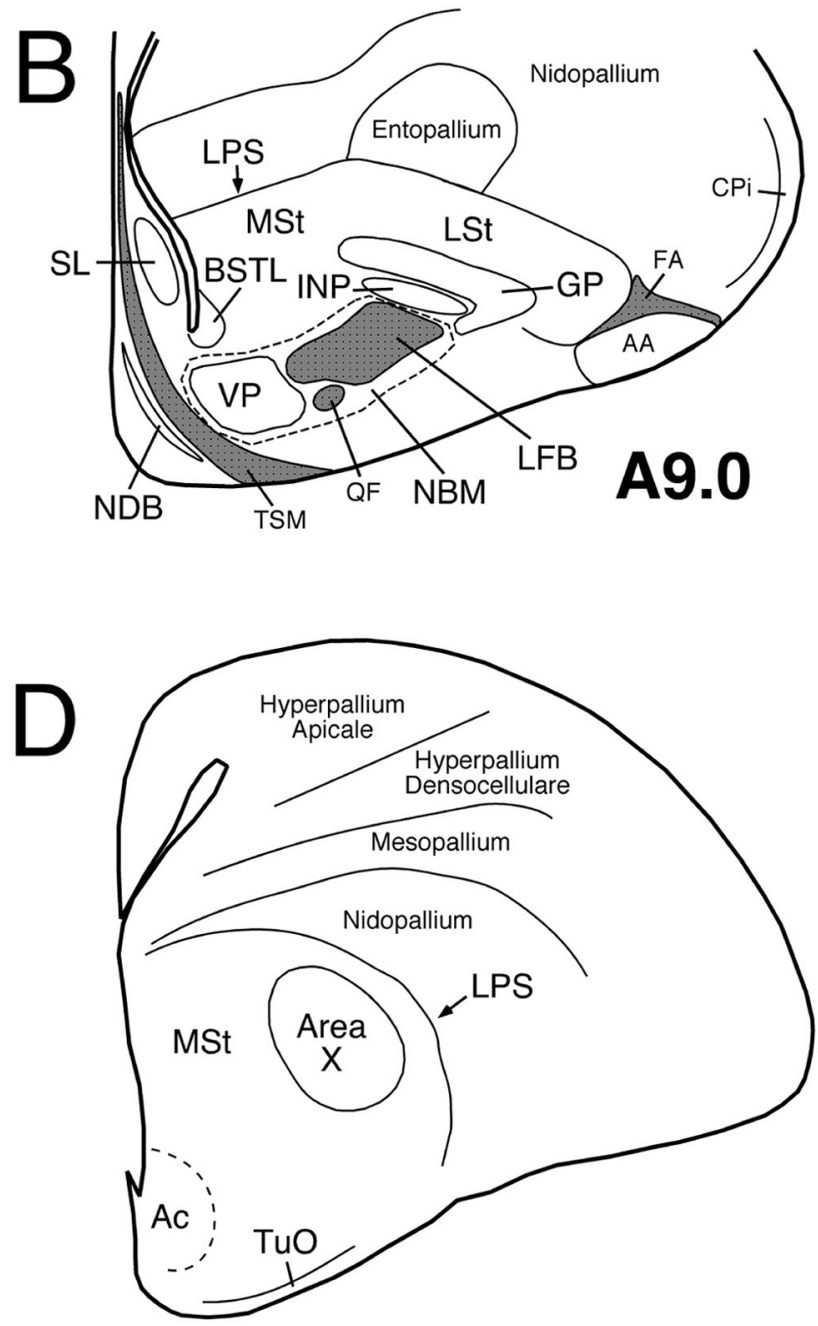

minalis; BSTM, medial nucleus of bed nucleus of stria terminalis; $\mathrm{CPi}$, cortex piriformis; FA, tractus fronto-arcopallialis; GP, globus pallidus; INP, intrapeduncular nucleus; LFB, lateral forebrain bundle; LPS, lamina pallio-subpallialis; LSt, lateral striatum; MSt, medial striatum; NBM, nucleus basalis magnocellularis; NDB, nucleus diagonalis Brocae; OM, tractus occipitomesencephalicus; QF, tractus quintofrontalis; SL, lateral septal nucleus; SM, medial septal nucleus; SpA, subpallial amygdala; TnA, taenial amygdala; TPO, area temporoparieto-occipitalis; TTP, tractus thalamopallialis; TSM, tractus septopallio-mesencephalicus; $\mathrm{TuO}$, tuberculum olfactorium; $\mathrm{VP}$, ventral pallidum.

substantia innominata, ventral pallidum, nucleus basalis of Meynert, and globus pallidus in mammals (Medina and Reiner, 1994). In both birds and mammals, these cholinergic neurons innervate the pallium (Woolf, 1991; Medina et al., 1994), and a comparable cell group has been identified in lizards and turtles (Medina et al., 1993; Powers and Reiner, 1993). The Forum thus recommended that this field of cholinergic neurons in birds be named the nucleus basalis magnocellularis (Table 2, Figs. 5D, 6B).

Cholinergic cell group in diagonal band region with noformal name in Karten and Hodos $\rightarrow$ Nucleus of the diagonal band (NDB). The Forum recognized, as proposed by Medina and Reiner (1994) based on their over- 
view of data in diverse mammalian, avian, and reptilian species, that the large cholinergic neurons near the fasciculus diagonalis Brocae (in the septal area and medial basal forebrain), and surrounding the septomesencephalic tract (the latter renamed here as the septopalliomesencephalic tract; see below), are homologous to the nucleus of the diagonal band of Broca in mammals and recommended that this name be used to refer to these neurons in birds (Table 2, Fig. 6B).

Nucleus septalis medialis (SM) $\rightarrow$ Nucleus septalis medialis (SM). Available hodological data on input from the hippocampal complex and output to the hypothalamus (Krayniak and Siegel, 1978b; Atoji et al., 2002) suggest homology of the medial septal nucleus of birds with the nucleus of the same name in mammals. A comparable cell group is present in members of all reptilian orders (Brauth and Kitt, 1980; Brauth, 1984; Reiner and Carraway, 1987; Medina et al., 1993; Smeets, 1994). The Forum thus recommended that the name for the medial septal nucleus remain unchanged (Table 2, Fig. 6C).

Nucleus septalis lateralis (SL) $\rightarrow$ Nucleus septalis lateralis (SL). Available hodological data on input from the hippocampal complex and output to the hypothalamus (Krayniak and Siegel, 1978b; Atoji et al., 2002), as well as neurochemical data (Reiner et al., 1984b, Reiner, 1994), suggest homology of the lateral septal nucleus of birds with the nucleus of the same name in mammals. A comparable cell group is present in all reptilian orders $(\mathrm{Br}-$ auth, 1984; Reiner, 1987; Smeets, 1994). The Forum thus recommended that the name for the lateral septal nucleus remain unchanged (Table 2, Figs. 5C,D, 6B,C).

\section{REVISED PALLIAL TELENCEPHALIC TERMINOLOGY}

\section{General Considerations}

An overwhelming body of data now supports the conclusion that the dorsal three-fourths of the cerebrum in birds (including what has been termed the neostriatum, hyperstriatum, and archistriatum) is pallial in nature and therefore homologous as a field to the brain region of mammals that includes the neocortex, claustrum, and pallial amygdala (Karten, 1969, 1991; Güntürkün, 1991; Wild et al., 1993; Butler, 1994; Veenman et al., 1995b; Striedter, 1997; Smith-Fernandez et al., 1998; Medina and Reiner, 2000; Puelles et al., 2000). Our goal in revising the pallial terminology for birds was thus to replace names that possessed incorrect implications of homology to parts of the basal ganglia (e.g., the neostriatum, hyperstriatum, and archistriatum) with names that possessed correct implications of homology, or at the very least not incorrect ones. Although additional pallial regions such as the hippocampus and piriform cortex also received consideration, these did not require name change, and relatively little discussion was devoted to them. Discussion of the evidence for one-to-one homology between specific parts of the avian pallium bearing "-striatum" in their name and specific parts of the pallium in mammals (Karten and Shimizu, 1989; Bruce and Neary, 1995; Striedter, 1997; Smith-Fernandez et al., 1998; Puelles et al., 2000; Reiner, 2000; Butler and Molnar, 2002; Butler et al., 2002) led to the conclusion that one-to-one homologies were not established with certainty, and in some cases might not exist, due to divergent evolution between birds and mammals.
This led then to the conclusion that the simplest course of action might be to replace "-striatum" with "-pallium" in the case of the above-noted structures and then devise some additional suitable prefixes or adjectives that distinguished the structures. Details of the possibilities considered will be presented in a special edition of Brain, Behavior and Evolution. In considering various choices, the Forum dealt with the new names for the neostriatum and hyperstriatum as a set, due to the relatedness of at least parts of these structures, whereas the archistriatal choices were considered separately. The results of the discussion follow.

\section{General comments on the hyperstriatum and neostriatum discussion}

In the existing terminology at the time of the Forum, the hyperstriatum ventrale (HV) and Wulst subregions (termed the hyperstriatum accessorium, hyperstriatum intercalatus superior, and hyperstriatum dorsale in the outdated nomenclature) were all named as parts of the hyperstriatum, but it has been clear for some time from developmental, hodological, neurochemical, and functional studies that they should not be linked in their names (Fig. 7A-D; Källén, 1953; Wächtler, 1985; Brauth et al., 1986; Wächtler and Ebinger, 1989; Csillag et al., 1993; Hodos, 1993; Shimizu et al., 1995; Husband and Shimizu, 1999; Denisenko-Nehrbass et al., 2000; Medina and Reiner, 2000; Sun and Reiner, 2000; Wada et al., 2001). The option approved by the Forum was to replace the term hyperstriatum in the various layers of Wulst with the term hyperpallium, to replace HV with mesopallium, and to replace neostriatum with nidopallium. These new terms are descriptive, because each prefix refers to an aspect of the relative degree of development or the location of the cell field to which it refers. For example, "hyper-" refers to an enlarged entity, which seems appropriate for the Wulst, because it is an enlarged (bulging) structure at the upper aspect of the pallium that represents a hypertrophied form of the dorsal cortex in reptiles (Medina and Reiner, 2000). A further advantage of the prefix "hyper-" is that it has already been used in the outdated name for the subdivisions of the Wulst. Thus, the term hyperpallium offers the benefit of easily linking the new term to the old, with abbreviations retained. The prefix "nido-", which means nest, was considered apt for the neostriatum, because it is the pallial structure in which the overlying pallial structures are nested. Moreover, "nido-" allows abbreviation retention for the subregions within the nidopallium, and its similarity to the outdated prefix for this region (i.e., "neo-') will facilitate learning the new term. Of course, the use of mesopallium (middle pallium) as a replacement for $\mathrm{HV}$ means that abbreviations need to change in this case. This was not seen as a serious disadvantage, however, because few subregions in mesopallium have been identified and named.

\section{Rationale for individual changes: the hyperstriatum}

General comments on the Wulst portions of the hyperstriatum. The named subdivisions of the Wulst have been referred to as pseudolayers (Medina and Reiner, 2000), because they seem to have some of the properties of cortical layers, except for pyramidal neurons with translaminar dendritic trees. Separate rationales for the renaming of the individual pseudolayers of the Wulst are 


discussed below. It needs to be noted that this name change does not affect the name of the individual functional areas (i.e., S1/M1 and V1) making up the Wulst, which each appear to span the depth of the various Wulst pseudolayers (Karten et al., 1973; Medina and Reiner, 2000; Wild and Williams, 2000; Table 3, Figs. 7, 8).

Hyperstriatum accessorium (HA) $\rightarrow$ Hyperpallium apicale $(\boldsymbol{H A})$. The HA gives rise to the extratelencephalic, as well as some intratelencephalic, projections of the Wulst (Karten et al., 1973; Reiner and Karten, 1983; Wild, 1992; Shimizu et al., 1995; Veenman et al., 1995b; Kröer and Günẗrkün, 1999; Wild and Williams, 1999, 2000). The Forum decided to replace "accessorium" with "apicale" because of the evolutionary or functional subordination to other parts of the hyperpallium implied by the term "accessorium." The term "apicale," by contrast, more accurately describes the location of the HA (at the summit of the telencephalon) and allows abbreviation retention as well (Table 3, Figs. 6D, 7A, 8A,B). Along the edge of the HA flanking the region that has been called the hyperstriatum intercalatus superior is a band of small, densely packed neurons that Karten et al. (1973) named the intercalated nucleus of the HA (IHA). This region receives visual and somatosensory inputs from retinorecipient and dorsal column nuclear-recipient parts of the thalamus and relays to the HA (Karten et al., 1973; Miceli and Reperant, 1985; Wild, 1987, 1989, 1997; Funke, 1989a,b; Korzeniewska and Güntürkün, 1990; G̈ntürkün, 1991; Medina and Reiner, 2000). With the change of the name of the HA to the hyperpallium apicale, we recommend that the IHA be referred to as the interstitial nucleus of the HA, and retain the same abbreviation. The Forum recommended using interstitial rather than intercalated in the name for the IHA for two reasons. First, the word interstitial more accurately describes the relation of this cell field to the HA than does the word intercalated, which implies it is intercalated between the HA and another region. Second, to call it the intercalated nucleus promotes confusion with the second main pseudolayer of the Wulst, namely, the structure that has been called the hyperstriatum intercalatus superior.

Hyperstriatum intercalatus superior (HIS) $\rightarrow \mathrm{Hy}$ perpallium intercalatum (HI). This Wulst pseudolayer was identified in Karten and Hodos (1967) and subsequent atlases (Stokes et al., 1974; Youngren and Phillips, 1978; Kuenzel and Masson, 1988; Matochik et al., 1991). The name indicated that this region is intercalated between two others within what was called the hyperstriatum, namely. the HA and the underlying Wulst region previously called the hyperstriatum dorsale. The Forum recommends that the region formerly known as the hyperstriatum intercalatus superior now be termed the hyperpallium intercalatum (Table 3, Figs. 7A, 8A,B). The Forum decided to delete the "superior" from the name and the " $S$ " from the abbreviation, because there is no hyperpallium intercalatus inferior. Note that switching interstitial for intercalatus in the name for the IHA eliminates any confusion between the IHA and HI (both had intercalatus in their prior names), and eliminating "superior" from the name for the HI avoids giving the impression that it should reside superior to either the IHA or HA.

Hyperstriatum dorsale (HD) $\rightarrow$ Hyperpallium densocellulare (HD). In eliminating the term hyperstriatum ventrale, the Forum eliminated a valid basis for retaining "dorsale" in the name for the HD. To retain the abbreviation HD, the Forum approved the term hyperpallium densocellulare (Table 3, Figs 6D, 7A, 8A,B). The adjective "densocellular" has been used previously in the neuroanatomical literature (e.g., Jiminez-Castellanos and Graybiel, 1987; Popken et al., 2000; Fudge and Haber, 2001), and it appropriately describes the HD, because it stands out as cell dense in Nissl-stained material (Karten and Hodos, 1967).

Hyperstriatum ventrale dorsoventrale (HVdv) $\rightarrow$ Mesopallium dorsale (MD). The upper division of what was called the HV was referred to as its dorsoventral part (Karten and Hodos, 1967). This subdivision is distinct cytoarchitectonically (Rehkämper et al., 1984) and neuro-
Fig. 7. Images of sections of pigeon, chicken, or male zebra finch brain labeled for various markers to show the location of the major pallial cell groups affected by the nomenclature revision. A: View of SP immunolabeling of a transverse section through the rostral pigeon telencephalon, focusing on the labeling in the Wulst (which can now also be called the hyperpallium) compared with the underlying part of the pallium (renamed by the Forum as the mesopallium). The image shows that the Wulst can be distinguished from the mesopallium by its enrichment in SP+ fibers, thereby supporting the conclusion of the Forum that separate names should be applied to the upper and lower parts of the pallial field that had previously been called the hyperstriatum in its entirety. B: Autoradiographic labeling of neurotensin receptors in a transverse section through the rostral pigeon telencephalon. C: Autoradiographic in situ hybridization histochemical labeling of dopamine D1B receptors in a transverse section through the rostral chick telencephalon. Both $\mathrm{B}$ and $\mathrm{C}$ show that the mesopallium can be distinguished from the hyperpallium (as well as the nidopallium), in this case by its enrichment in neurotensin and dopamine D1B receptors. This further supports the conclusion of the Forum that separate names should be applied to the upper and lower parts of the pallial field that had previously been called the hyperstriatum in its entirety. D: Autoradiographic in situ hybridization histochemical labeling of a sagittal section through the male zebra finch brain for the GluR1 subunit of the AMPA-type glutamate receptor, providing additional neurochemical evidence for a distinction between the hyperpallium and mesopallium. Of further note in $\mathrm{D}$ is the fact that the three primary sensory thalamorecipient fields of the nidopallium (the nucleus basorostralis [Bas], the entopallium [E], and the L2 portion of Field L [L2]), two of which are present at the illustrated level (L2 and Bas), share the trait among nidopallial fields of being poor in GluR1. Additionally, song control-related nuclei, such as the HVC and the robust nucleus of the arcopallium (RA), stand out as poor in GluR1, whereas Area X of the striatum stands out as rich. E,F: Views of dopamine immunolabeling of transverse sections through successively more caudal levels of the pigeon telencephalon. Note the enrichment of dopaminergic fibers between the globus pallidus (GP) and occipitomesencephalic tract $(\mathrm{OM})$ shown in $\mathrm{E}$, which defines the field here identified as the subpallial amygdala $(\mathrm{SpA})$. The labeling in $\mathrm{F}$ serves to distinguish the dopamine fiber-rich dorsal arcopallium (AD) from the underlying intermediate arcopallium (AI). AA, arcopallium anterius; AD, arcopallium dorsale; AI, arcopallium intermedium; AM, arcopallium mediale; BSTL, lateral part of bed nucleus of stria terminalis; HD, hyperpallium densocellulare; HA, hyperpallium apicale; $\mathrm{HI}$, hyperpallium intercalatum; IHA, interstitial nucleus of the hyperpallium intercalatum; LMAN, lateral magnocellular nucleus of the anterior nidopallium; LSt, lateral striatum; MD, mesopallium dorsale; MSt, medial striatum; MV, mesopallium ventrale; St, striatum; $\mathrm{TeO}$, tectum opticum; TnA, nucleus taeniae of the amygdala. (A, adapted from Shimizu and Karten, 1990; B, adapted from Brauth et al., 1986; C, adapted from Sun and Reiner, 2000; D, adapted from Wada et al., 2001) Scale bar $=0.5 \mathrm{~mm}$ in A; $1 \mathrm{~mm}$ in B-F. 
TABLE 3. New Terminology for Hyperstriatum

\begin{tabular}{|c|c|c|c|c|}
\hline $\begin{array}{l}\text { Structure and Karten- } \\
\text { Hodos (or other) term for } \\
\text { structure (abbreviation) }\end{array}$ & $\begin{array}{l}\text { Latin name adopted } \\
\text { by Forum } \\
\text { (abbreviation) }\end{array}$ & $\begin{array}{l}\text { English name } \\
\text { adopted by Forum } \\
\text { (abbreviation) }\end{array}$ & Comments & $\begin{array}{l}\text { Refs. pertinent to the } \\
\text { new name }\end{array}$ \\
\hline \multicolumn{5}{|l|}{ Wulst and Wulst subdivisions } \\
\hline $\begin{array}{l}\text { Hyperstriatum accessorium } \\
\text { (HA) }\end{array}$ & $\begin{array}{l}\text { Hyperpallium apicale } \\
\text { (HA) }\end{array}$ & $\begin{array}{l}\text { Apical part of the } \\
\text { hyperpallium (HA) }\end{array}$ & $\begin{array}{l}\text { The term apical more aptly describes } \\
\text { this region than does the term } \\
\text { accessory }\end{array}$ & $\begin{array}{l}\text { Karten et al., } 1973 \\
\text { Medina and Reiner, } 2000 \\
\text { Wild and Williams, } 2000\end{array}$ \\
\hline $\begin{array}{l}\text { Nucleus intercalatus } \\
\text { hyperstriatum accessorium } \\
\text { in Karten et al., } 1973 \\
\text { (IHA) }\end{array}$ & $\begin{array}{l}\text { Nucleus interstitialis } \\
\text { hyperpallii apicalis } \\
\text { (IHA) }\end{array}$ & $\begin{array}{l}\text { Interstitial part of the } \\
\text { hyperpallium apicale } \\
\text { (IHA) }\end{array}$ & $\begin{array}{l}\text { The term interstitial more aptly } \\
\text { describes this region than does the } \\
\text { term intercalated }\end{array}$ & $\begin{array}{l}\text { Karten et al., } 1973 \\
\text { Medina and Reiner, } 2000\end{array}$ \\
\hline $\begin{array}{l}\text { Hyperstriatum intercalatus } \\
\text { superior (HIS) }\end{array}$ & $\begin{array}{l}\text { Hyperpallium } \\
\text { intercalatum (HI) }\end{array}$ & $\begin{array}{l}\text { Intercalated part of the } \\
\text { hyperpallium }(\mathrm{HI})\end{array}$ & Superior in name not appropriate & Karten et al., 1973 \\
\hline Hyperstriatum dorsale (HD) & $\begin{array}{l}\text { Hyperpallium } \\
\text { densocellulare (HD) }\end{array}$ & $\begin{array}{l}\text { Densocellular part of the } \\
\text { hyperpallium (HD) }\end{array}$ & $\begin{array}{l}\text { Dorsale in name no longer apt since } \\
\text { the region termed HV now called } \\
\text { mesopallium }\end{array}$ & Karten et al., 1973 \\
\hline \multicolumn{5}{|l|}{ Hyperstriatum ventrale } \\
\hline Hyperstriatum ventrale (HV) & Mesopallium (M) & Mesopallium (M) & & Rehkämper et al., 1984 \\
\hline $\begin{array}{l}\text { Hyperstriatum ventrale } \\
\text { dorso-ventrale (HVdv) }\end{array}$ & $\begin{array}{l}\text { Mesopallium dorsale } \\
\text { (MD) }\end{array}$ & $\begin{array}{l}\text { Dorsal mesopallium } \\
\text { (MD) }\end{array}$ & & $\begin{array}{l}\text { Wächtler, } 1985 \\
\text { Csillag et al., } 1990\end{array}$ \\
\hline $\begin{array}{l}\text { Hyperstriatum ventrale } \\
\text { ventro-ventrale (HVvv) }\end{array}$ & $\begin{array}{l}\text { Mesopallium ventrale } \\
\quad \text { (MV) }\end{array}$ & $\begin{array}{l}\text { Ventral mesopallium } \\
\text { (MV) }\end{array}$ & $\begin{array}{l}\text { Recommend motor nucleus of } \\
\text { trigeminus be abbreviated MNV to } \\
\text { prevent conflict with abbreviation } \\
\text { for ventral mesopallium }\end{array}$ & $\begin{array}{l}\text { Wächtler, } 1985 \\
\text { Csillag et al., } 1990\end{array}$ \\
\hline $\begin{array}{l}\text { Oval nucleus of the } \\
\text { hyperstriatum ventrale } \\
\text { (Hvo) }\end{array}$ & $\begin{array}{l}\text { Nucleus ovalis } \\
\text { mesopallii (MO) }\end{array}$ & $\begin{array}{l}\text { Oval nucleus of } \\
\text { mesopallium (MO) }\end{array}$ & Part of parrot vocal control circuit & $\begin{array}{l}\text { Striedter, } 1994 \\
\text { Durand et al., } 1997 \\
\text { Jarvis et al., } 1998\end{array}$ \\
\hline $\begin{array}{l}\text { Caudal medial } \\
\text { hyperstriatum ventrale } \\
\text { (CMHV) }\end{array}$ & $\begin{array}{l}\text { Mesopallium } \\
\text { caudomediale (CMM) }\end{array}$ & $\begin{array}{l}\text { Caudomedial } \\
\text { mesopallium (CMM) }\end{array}$ & Part of avian auditory circuit & $\begin{array}{l}\text { Vates et al., } 1996 \\
\text { Jarvis et al., } 2000\end{array}$ \\
\hline $\begin{array}{l}\text { Intermediate medial } \\
\text { hyperstriatum ventrale } \\
\text { (IMHV) }\end{array}$ & $\begin{array}{l}\text { Mesopallium } \\
\text { intermediomediale } \\
\text { (IMM) }\end{array}$ & $\begin{array}{l}\text { Intermediate medial } \\
\text { mesopallium (IMM) }\end{array}$ & Involved in filial imprinting in chicks & $\begin{array}{l}\text { Rose and Csillag, } 1985 \\
\text { Patel et al., } 1988 \\
\text { Csillag et al., } 1990\end{array}$ \\
\hline
\end{tabular}

chemically from the lower part of the mesopallium (Fig. 7B,C; Wächtler, 1985; Faber et al., 1989; Wächtler and Ebinger, 1989; Csillag et al., 1993; Montagnese et al., 1993; Sun and Reiner, 2000). The term "dorsoventrale" was deemed needlessly complex, as already noted in Kuenzel and Masson (1988), and so the subordinate part of the name for this region has been simplified from that in Karten and Hodos (1967) to "dorsale."

Hyperstriatum ventrale ventroventrale (HVvv) $\rightarrow$ Mesopallium ventrale (MV). The lower division of the old HV was called its ventroventral part (Karten and Hodos, 1967). As noted, this subdivision is distinct cytoarchitectonically (Rehkämper et al., 1984) and neurochemically from the upper part of the mesopallium (Fig. 7B,C; Wächtler, 1985; Faber et al., 1989; Wächtler and Ebinger, 1989; Csillag et al., 1993; Montagnese et al., 1993; Sun and Reiner, 2000). The term "ventroventrale" was also deemed needlessly complex, as already noted in Kuenzel and Masson (1988), and so the subordinate name for this region has been simplified from that in Karten and Hodos (1967) to "ventrale".

Oval nucleus of the hyperstriatum ventrale $(\mathrm{HVo}) \rightarrow$ Oval nucleus of the mesopallium (MO). The oval nucleus of the $\mathrm{HV}$ is a distinct region recognized in parrots that is part of their telencephalic vocal control circuit (Striedter, 1994; Durand et al., 1997). A similar region has also been observed in songbirds and hummingbirds (Jarvis et al., 1998, 2000). With the renaming of the HV, this region becomes the oval nucleus of the mesopallium.

Caudal medial hyperstriatum ventrale (CMHV) $\rightarrow$ Caudal medial mesopallium (CMM). The caudal medial HV is a region recognized in guinea fowl, chicken, pigeons, songbirds, hummingbirds, and parrots as part of their telencephalic auditory circuit (Bonke et al., 1979a; Heil and Scheich, 1991a,b; Wild et al., 1993; Vates et al., 1996; Jarvis et al., 2000. With the renaming of HV, this region becomes the caudal medial mesopallium.

Intermediate medial hyperstriatum ventrale (IMHV) $\rightarrow$ Intermediate medial mesopallium (IMM). The region termed the IMHV has been recognized as a functionally and neurochemically definable cell field in studies of filial imprinting and passive avoidance learning in chicks (Horn, 1985; Rose and Csillag, 1985; Patel et al., 1988; Csillag et al., 1993). With the renaming of the HV, this region becomes the intermediate medial mesopallium.

\section{Rationale for individual changes: the neostriatum}

General comments on the neostriatum. The new term nidopallium maintains existing abbreviations, which is a considerable advantage given the large number of subregions within it (Rehkämper et al., 1985) that have names built upon the outgoing term neostriatum (Table 4, Figs. 7D, 8A-D). For example, the frontal, intermediate, and caudal neostriatum become the frontal, intermediate, and caudal nidopallium, and abbreviations remain unchanged. Because most papers and figures mainly use abbreviations to refer to specific structures, abbreviation retention for nidopallial structures will facilitate linking the old and new terms.

Use of the term neostriatum in mammals. The term "neostriatum" should also be discarded in mammals, but for somewhat different reasons than in birds. In mammals, the term "neostriatum" is used by many investigators to refer to the caudatoputamen, but the term "striatum" is also used to refer to these very same structures 

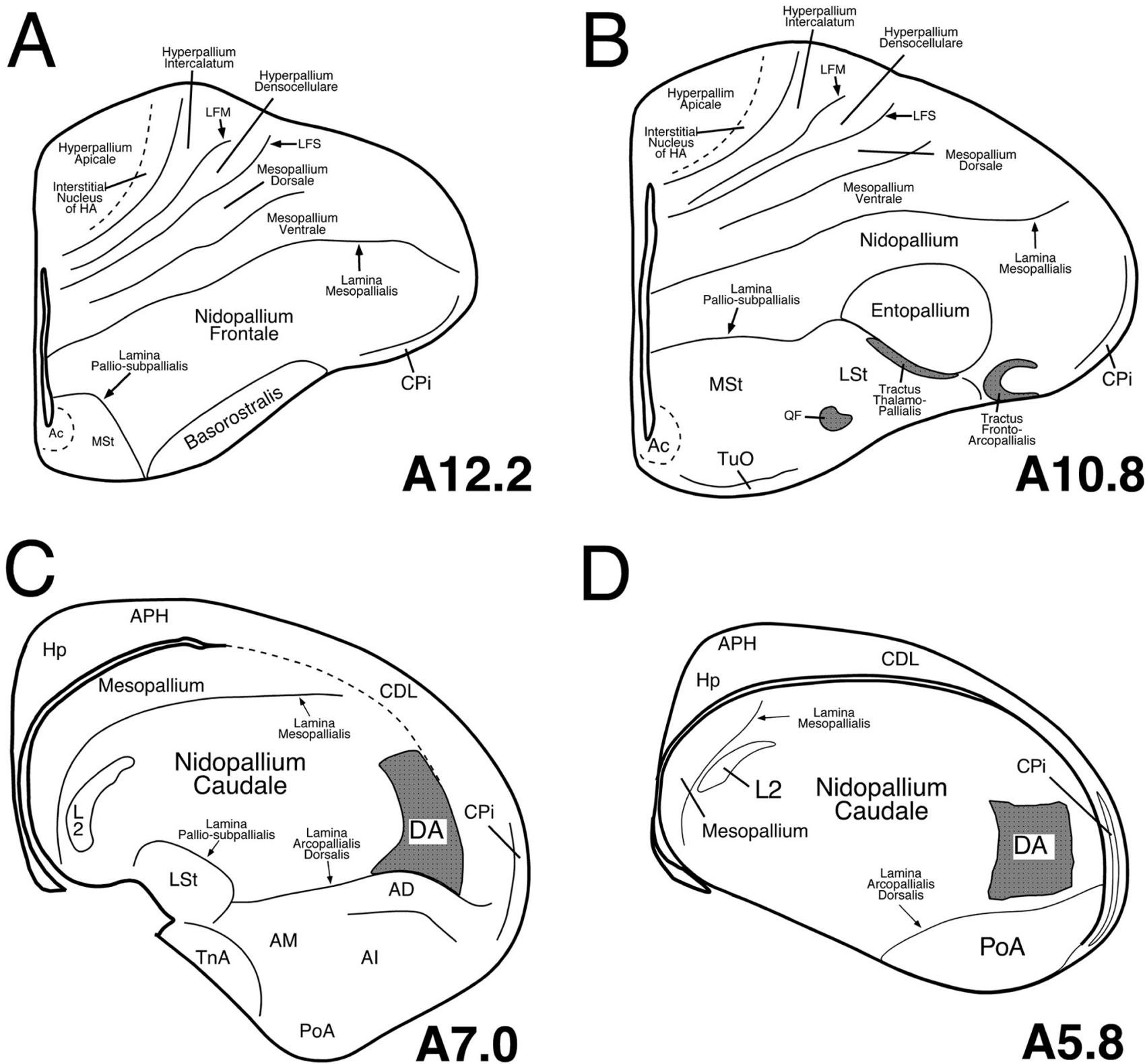

$\mathrm{D}$

Fig. 8. A-D: Line drawings of a rostral to caudal series of transverse sections of chicken brain illustrating the locations of the major pallial cell groups whose names have been revised by the Nomenclature Forum. The schematics shown are all simplified versions of plates from the stereotaxic atlas of chick brain by Kuenzel and Masson (1988), and numbers to the lower right of each drawing represent the stereotaxic level of that section. Fiber tracts are shaded gray. Ac, nucleus accumbens; $\mathrm{AD}$, arcopallium dorsale; $\mathrm{AI}$, arcopallium inter-

(Carpenter, 1976). Thus the "neo-" in "neostriatum" is superfluous for mammals. In addition, the term "neostriatum" in mammals is only useful if there is some region that is old striatum (i.e., paleostriatum). Although the term "paleostriatum" was once used to refer to the globus pallidus in mammals (Carpenter, 1976), the term was abandoned long ago, and the assumption that the pallidum is evolutionarily older than the striatum has been

disproved (Reiner and Carraway, 1985; Northcutt et al., 1988; Reiner et al., 1998a). Continued use of terms such as paleostriatum and neostriatum to refer to parts of the mammalian basal ganglia thus perpetuates discredited ideas about the evolution of the basal ganglia.

General comments on sensory cell groups within the nidopallium. Three major nidopallial cell groups receive extratelencephalic sensory input in birds. These cell

medium; AM, arcopallium mediale; APH, area parahippocampalis; $\mathrm{CDL}$, area corticoidea dorsolateralis; $\mathrm{CPi}$, cortex piriformis; $\mathrm{DA}$, tractus dorso-arcopallialis; Hp, hippocampus; L, Field L; LFM, lamina tum; MSt, medial striatum; PoA, posterior nucleus of pallial amygdala; $\mathrm{QF}$, tractus quintofrontalis; $\mathrm{TnA}$, taenial amygdala; TuO, tuberculum olfactorium. 
TABLE 4. New Terminology for Neostriatum

\begin{tabular}{|c|c|c|c|c|}
\hline $\begin{array}{l}\text { Structure and Karten- } \\
\text { Hodos (or other) term for } \\
\text { structure (abbreviation) }\end{array}$ & $\begin{array}{c}\text { Latin name adopted } \\
\text { by Forum } \\
\text { (abbreviation) }\end{array}$ & $\begin{array}{c}\text { English name adopted } \\
\text { by Forum } \\
\text { (abbreviation) }\end{array}$ & Comments & $\begin{array}{l}\text { Refs. pertinent to the } \\
\text { new name }\end{array}$ \\
\hline \multicolumn{5}{|l|}{ Neostriatum and Subdivisions } \\
\hline Neostriatum $(\mathrm{N})$ & Nidopallium (N) & Nidopallium (N) & Abbreviation retained & \\
\hline Neostriatum frontale (NF) & $\begin{array}{l}\text { Nidopallium frontale } \\
\text { (NF) }\end{array}$ & Frontal nidopallium (NF) & Abbreviation retained & \\
\hline $\begin{array}{l}\text { Neostriatum intermedium } \\
\text { (NI) }\end{array}$ & $\begin{array}{l}\text { Nidopallium } \\
\text { intermedium (NI) }\end{array}$ & $\begin{array}{l}\text { Intermediate nidopallium } \\
\text { (NI) }\end{array}$ & Abbreviation retained & \\
\hline Neostriatum caudale (NC) & $\begin{array}{l}\text { Nidopallium caudale } \\
\text { (NC) }\end{array}$ & Caudal nidopallium (NC) & Abbreviation retained & \\
\hline $\begin{array}{l}\text { Neostriatum } \\
\text { caudolaterale-defined by } \\
\text { work of Divac and } \\
\text { Güntürkün (NCL) }\end{array}$ & $\begin{array}{l}\text { Nidopallium } \\
\text { caudolaterale (NCL) }\end{array}$ & $\begin{array}{l}\text { Caudolateral nidopallium } \\
\text { (NCL) }\end{array}$ & Abbreviation retained & $\begin{array}{l}\text { Mogenson and Divac, } 1982 \\
\text { Reiner, } 1986 \\
\text { Güntürkün, } 1997\end{array}$ \\
\hline Ectostriatum $(\mathrm{E})$ & $\begin{array}{l}\text { Nucleus entopalliallis or } \\
\text { entopallium (E) }\end{array}$ & $\begin{array}{l}\text { The entopallial nucleus or } \\
\text { the entopallium }(\mathrm{E})\end{array}$ & Abbreviation retained & Benowitz and Karten, 1976 \\
\hline Nucleus basalis (Bas) & $\begin{array}{l}\text { Nucleus basorostralis } \\
\text { pallii (Bas) }\end{array}$ & $\begin{array}{l}\text { The basorostral pallial } \\
\text { nucleus (Bas) }\end{array}$ & $\begin{array}{l}\text { Changed name to avoid } \\
\text { confusion with cholinergic } \\
\text { basal forebrain cell group }\end{array}$ & $\begin{array}{l}\text { Wild et al., } 1985 \\
\text { Wild and Farabaugh, } 1996 \\
\text { Dubbeldam and Visser, } 1987 \\
\text { Wild et al., } 1997 \\
\text { Wild et al., } 2001 \\
\text { Witkovsky et al., } 1973\end{array}$ \\
\hline $\begin{array}{l}\text { Field L identified as } \\
\text { auditory area by Karten } \\
1968(\mathrm{~L})\end{array}$ & Area L pallii (L) & Field L (L) & No change recommended & $\begin{array}{l}\text { Karten, } 1968 \\
\text { Bonke, } 1979 \mathrm{a}, \mathrm{b}\end{array}$ \\
\hline $\begin{array}{l}\text { Nidopallial area mistakenly } \\
\text { called caudal nucleus of } \\
\text { hyperstriatum ventrale by } \\
\text { Nottebohm et al., } 1976 \\
\text { (HVc) }\end{array}$ & HVC (None) & HVC (None) & $\begin{array}{l}\text { No easy solution for correcting } \\
\text { original naming error for } \\
\text { this structure; thus, HVC } \\
\text { recommended as formal } \\
\text { name }\end{array}$ & $\begin{array}{l}\text { Nottebohm et al., } 1976 \\
\text { Fortune and Margoliash, } 1995 \\
\text { Brenowitz et al., } 1997\end{array}$ \\
\hline $\begin{array}{l}\text { Lateral magnocellular } \\
\text { nucleus of the anterior } \\
\text { neostriatum (LMAN) }\end{array}$ & $\begin{array}{l}\text { Nucleus lateralis } \\
\text { magnocellularis } \\
\text { nidopallii anterioris } \\
\text { (LMAN) }\end{array}$ & $\begin{array}{l}\text { Lateral magnocellular } \\
\text { nucleus of anterior } \\
\text { nidopallium (LMAN) }\end{array}$ & $\begin{array}{l}\text { Abbreviation retained, but } \\
\text { capitalize L for clarity }\end{array}$ & $\begin{array}{l}\text { Nottebohm et al., } 1976 \\
\text { Bottjer et al., } 1989\end{array}$ \\
\hline $\begin{array}{l}\text { Medial magnocellular } \\
\text { nucleus of the anterior } \\
\text { neostriatum (MMAN) }\end{array}$ & $\begin{array}{l}\text { Nucleus medialis } \\
\text { magnocellularis } \\
\text { nidopallii anterioris } \\
\text { (MMAN) }\end{array}$ & $\begin{array}{l}\text { Medial magnocellular } \\
\text { nucleus of anterior } \\
\text { nidopallium (MMAN) }\end{array}$ & $\begin{array}{l}\text { Abbreviation retained but } \\
\text { capitalize } \mathrm{M} \text { for consistency }\end{array}$ & $\begin{array}{l}\text { Nottebohm et al., } 1976 \\
\text { Bottjer et al., } 1989\end{array}$ \\
\hline $\begin{array}{l}\text { Nucleus interface of the } \\
\text { neostriatum (Nif) }\end{array}$ & $\begin{array}{l}\text { Nucleus interfacialis } \\
\text { nidopallii (Nif) }\end{array}$ & $\begin{array}{l}\text { Nucleus interface of the } \\
\text { nidopallium (Nif) }\end{array}$ & $\begin{array}{l}\text { Abbreviation retained, but } \\
\text { capitalize I for consistency }\end{array}$ & $\begin{array}{l}\text { Nottebohm et al., } 1982 \\
\text { Nordeen and Nordeen, } 1997 \\
\text { Margoliash, } 1997\end{array}$ \\
\hline $\begin{array}{l}\text { Caudomedial neostriatum } \\
\text { (NCM) }\end{array}$ & $\begin{array}{l}\text { Nidopallium } \\
\text { caudomediale (NCM) }\end{array}$ & $\begin{array}{l}\text { Caudal medial } \\
\text { nidopallium (NCM) }\end{array}$ & Abbreviation retained & $\begin{array}{l}\text { Mello et al., } 1992 \\
\text { Vates et al., } 1996 \\
\text { Jarvis et al., } 2000\end{array}$ \\
\hline $\begin{array}{l}\text { Oval nucleus of the anterior } \\
\text { neostriatum in parrots } \\
\text { (Nao) }\end{array}$ & $\begin{array}{l}\text { Nucleus ovalis nidopallii } \\
\text { anterioris (NAO) }\end{array}$ & $\begin{array}{l}\text { Oval nucleus of the } \\
\text { anterior nidopallium } \\
\text { (NAO) }\end{array}$ & $\begin{array}{l}\text { Abbreviation retained, but } \\
\text { capitalize O for consistency }\end{array}$ & $\begin{array}{l}\text { Brauth and McHale, } 1988 \\
\text { Striedter, } 1994 \\
\text { Durand et al., } 1997 \\
\text { Jarvis and Mello, } 2000\end{array}$ \\
\hline $\begin{array}{l}\text { Medial oval nucleus of the } \\
\text { anterior neostriatum in } \\
\text { parrots (Naom) }\end{array}$ & $\begin{array}{l}\text { Nucleus ovalis nidopallii } \\
\text { anterioris, pars } \\
\text { medialis (NAOM) }\end{array}$ & $\begin{array}{l}\text { Medial part of the oval } \\
\text { nucleus of the anterior } \\
\text { nidopallium (NAOM) }\end{array}$ & $\begin{array}{l}\text { Abbreviation retained but } \\
\text { capitalize OM for } \\
\text { consistency }\end{array}$ & $\begin{array}{l}\text { Brauth and McHale, } 1988 \\
\text { Striedter, } 1994 \\
\text { Durand et al., } 1997 \\
\text { Jarvis and Mello, } 2000\end{array}$ \\
\hline $\begin{array}{l}\text { Central nucleus of the } \\
\text { lateral neostriatum in } \\
\text { parrots (NLc) }\end{array}$ & $\begin{array}{l}\text { Nucleus centralis } \\
\text { nidopallii lateralis } \\
\text { (NLC) }\end{array}$ & $\begin{array}{l}\text { Central nucleus of the } \\
\text { lateral nidopallium } \\
\text { (NLC) }\end{array}$ & $\begin{array}{l}\text { Abbreviation retained, but } \\
\text { capitalize } \mathrm{C} \text { for consistency }\end{array}$ & $\begin{array}{l}\text { Brauth and McHale, } 1988 \\
\text { Striedter, } 1994 \\
\text { Durand et al., } 1997 \\
\text { Jarvis and Mello, } 2000\end{array}$ \\
\hline
\end{tabular}

${ }^{1}$ Summary of the nomenclature recommendations of the Forum for the neostriatum and the major subdivisions within it, proceeding largely in a rostral to caudal order (with specialized structures involved in vocal control or audition listed last). For each structure considered, the first column of the table shows the original name assigned (typically from specialized structures involved in vocal control or audition listed last). For each structure considered, the first column of the table shows the original name assigned (typically from
Karten and Hodos, 1967) and the original abbreviation, the next column shows the Latin variant and abbreviation of the new (or carried over) term recommended by the Forum, Karten and Hodos, 1967) and the original abbreviation, the next column shows the Latin variant and abbreviation of the new (or carried over) term recommended by the Forum,
the next shows the English variant and abbreviation of the new (or carried over) recommended term, and the final two columns present any noteworthy comments about the change and key references pertinent to the change.

groups have been known as the ectostriatum (which receives visual input from nucleus rotundus of the thalamus; Karten and Revzin, 1966; Karten, 1969; Karten and Hodos, 1970), Field L (which receives auditory input from the nucleus ovoidalis of the thalamus; Karten, 1968, 1969; Wild et al., 1993), and the nucleus basalis (which receives trigeminal input directly from the principal sensory nucleus of the pons; Witkovsky et al., 1973). The ectostriatum and nucleus basalis but not Field L (Table 3, Figs. 7D, 8A-D) were renamed by the Forum for reasons discussed below. Each of these three regions consists of a core, which receives the majority of the ascending sensory input, and a surrounding shell, which mainly receives input from the core. The terminology that has been used for the shell region is problematic.

For example, Field $\mathrm{L}$ is often taken to mean the region in the caudomedial neostriatum (now the nidopallium) defined by Rose (1914) and shown by Karten (1969) in pigeons, and later in other avian species (Kelley and Nottebohm, 1979; Brauth et al., 1987; Vates et al., 1996), to receive a prominent input from nucleus ovoidalis. The work of Scheich and colleagues (e.g., Bonke et al., 1979a,b; Müller and Scheich, 1985) led to recognition that the auditory field in the caudomedial nidopallium was actually larger than the ovoidalis-recipient Field L alone. Thus, the ovoidalis- thalamorecipient zone was named L2 (Fig. 7D), and the regions immediately adjacent to $\mathrm{L} 2$, which receive L2 input as well as thalamic input from the periovoidalis region, were named L1 and L3. In guinea fowl, chicken, and pigeon, L1 is dorsomedial and L3 is ventrolateral to L2 (Bonke et al., 1979a; Heil and Scheich, 1985; Müller and Scheich, 1985; Wild et al., 1993). In songbirds, however, L1 is rostrodorsal, and L3 is caudoventral to L2 (Müller and Scheich, 1985; Fortune and Margoliash, 1992; 
Vates et al., 1996). As a consequence of the presence of subfields, the term Field $L$ has come to have two different uses in the literature, one in which it refers to L2 alone and one in which it refers to L1-3.

Similar problems arise with respect to the ectostriatum, because in some studies the core and shell are together referred to as the ectostriatum, whereas in others only the thalamorecipient core is called the ectostriatum (Karten and Revzin, 1966; Karten and Hodos, 1970; Benowitz and Karten, 1976; Nixdorf and Bischof, 1982; Husband and Shimizu, 1999). Because the structure that has been known as the nucleus basalis also shows a core and shell organization, a similar problem exists for it (Fig. 7D; Wild and Zeigler, 1980; Wild et al., 1985; Veenman and Gottschaldt, 1986; Dubbeldam and Visser, 1987; Wild and Farabaugh, 1996). The Forum concluded that it would be desirable to develop a uniform and consistent terminology for these three sensory areas in the nidopallium and will make recommendations in a separate publication specifically devoted to this issue, in the special nomenclature issue of Brain, Behavior and Evolution.

Neostriatum caudolaterale (NCL) $\rightarrow$ Nidopallium caudolaterale (NCL). The caudolateral neostriatum has been reported to possess neurochemical and functional similarities to the prefrontal cortex in mammals (Mogensen and Divac, 1982; Reiner, 1986). Although these similarities are thought to represent an instance of analogy due to parallel evolution, nonetheless, as a consequence of its resemblance to prefrontal cortex, the NCL has been the focus of considerable interest (Gütürkün, 1997; Durstewitz et al., 1999; Riters et al., 1999). The new term nidopallium serves to retain the existing abbreviations for the NCL, which is an advantage, given the many publications on this region (Table 4).

Ectostriatum (E) $\rightarrow$ Entopallium $(\boldsymbol{E})$. The term ectostriatum, broken into its prefix and root word, means "outside the striatum." Because what has been called the ectostriatum is outside the striatum, as we define the striatum here, the term ectostriatum is actually semantically appropriate and could have been retained without any erroneous denotation. Nonetheless, the term ectostriatum was linked to the set of incorrect names for the pallium in birds by the root word "-striatum" and could be misconstrued as being part of the striatum. For this reason, the name for the ectostriatum was changed to entopallium, which means "within (ento-) the pallium." This new term also retains existing abbreviations for this region and its prefix sounds similar to that for the ectostriatum (Table 4, Fig. 8B).

Nucleus basalis (Bas) $\rightarrow$ Nucleus basorostralis pallii (Bas). Although the term nucleus basalis as it has been used in birds to refer to a sensory structure of the pallium does not possess any root words implying an association with the basal ganglia, the name used for this sensory cell group needed to be changed because the Forum had already reserved that same name for the avian homologue of the basal forebrain cholinergic cell field in mammals (Table 2). The structure that has been called nucleus basalis in birds is not located in the subpallium and is not a cholinergic cell group, but rather is a trigeminorecipient pallial sensory cell group (Witkovsky et al., 1973; Wild et al., 1985) and, in some species, also a general somatosensory recipient nucleus (Wild et al., 1997, 2001). It also receives an auditory input from the nucleus of the lateral lemniscus, as well as an input from the vestibular system ((Arends and Zeigler, 1986; Wild and Farabaugh, 1996; Wild et al., 2001). To prevent confusion with the cholinergic nucleus basalis of mammals, the Forum recommended that the old nucleus basalis of birds be renamed the nucleus basorostralis of the pallium, which describes its position in the telencephalon, with no abbreviation change (Table 4, Figs. 7D, 8A).

Field $\boldsymbol{L} \rightarrow$ Field $\boldsymbol{L}$. The nidopallial region containing the primary auditory thalamorecipient zone was neither recognized to be a distinct region nor assigned a name in Karten and Hodos (1967). However, the experimental work of Karten (1968) established that this zone largely coincides with the cytoarchitectonically defined Field L of Rose (1914), and this name subsequently became entrenched in the literature on this region (Bonke et al., 1979a; Kelley and Nottebohm, 1979; Brauth et al., 1987; Brauth and McHale, 1988; Fortune and Margoliash, 1992; Wild et al., 1993; Vates et al., 1996). For this reason, the Forum concluded that it would be disruptive to change the name of this region to an actual name rather than a letter, given the many studies devoted to it; thus, the Forum recommended that the name Field $\mathrm{L}$ be retained (Table 4 , Figs. 7D, 8C,D).

HVC (Higher vocal center) or HVc $\rightarrow H V C$. The region of the songbird brain termed the HVC (Table 4, Fig. 7D) was first recognized as part of the telencephalic song control circuit by Nottebohm et al. (1976). It was (erroneously) thought to occupy a caudal part of the hyperstriatum ventrale and was thus named the hyperstriatum ventrale pars caudale, abbreviated HVc. Subsequent work, however, recognized that this region is in actuality located within the pallial field that has been called the neostriatum (Paton et al., 1981). To retain the abbreviation, which had already become entrenched, but to eliminate the inaccurate name, Nottebohm (1987) suggested calling this region the higher vocal center and abbreviating it with all capital letters. Subsequently, the concern was raised that the HVC was arguably not the apex of a hierarchy of vocal centers of the brain, making the name unwarranted (Margoliash et al., 1994). These issues are discussed by Fortune and Margoliash (1995) and by Brenowitz et al. (1997), who recommended use of "HVc" as the proper name for the nucleus. Since that time, however, some investigators have continued to use the term "high (or higher) vocal center" in published reports, whereas others have used "HVc" or "HVC" as a proper name. For the sake of consistency, the Forum suggested using HVC as the proper name and recommends against using HVc or any form of the term "higher vocal center."

Other neostriatal auditory and vocal nuclei of songbirds $\rightarrow$ Other nidopallial auditory and vocal nuclei of songbirds. Several additional nuclei have been identified in songbirds that are important for auditory processing or are related to song learning and control, including the lateral magnocellular nucleus of the anterior neostriatum (IMAN or LMAN; Fig. 7D), the medial magnocellular nucleus of the anterior neostriatum (mMAN or MMAN), and the caudomedial neostriatum (NCM; Nottebohm et al., 1976; Bottjer et al., 1989; Mello et al., 1992; Mello and Clayton, 1994; Margoliash, 1997; Nordeen, 1997; Jarvis et al., 2000). With the renaming of neostriatum, the name for each of these is altered by substituting nidopallium for neostriatum, and the established abbreviation remains the same (Table 4). The nucleus interface (NIf) represents an additional major telencephalic constit- 
uent of auditory and song-control circuitry (Nottebohm et al., 1982; Vates et al., 1996). Although this nucleus, too, is located in what has been called the neostriatum, the word neostriatum does not appear in the outdated name for NIf. To emphasize its location, the Forum adopted for this structure the official name nucleus interface of the nidopallium (or its Latin equivalent), and thus its abbreviation does not need to be revised. For these abbreviations, as for others, the Forum recommends using capital letters for all main words represented in the abbreviations, with lower case only for subordinate words or letters. In the instance of the lateral magnocellular nucleus of the anterior nidopallium, this practice eliminates the confusion caused by the resemblance among the capital letter I, the lower case letter $\mathrm{L}$, and the number 1.

Neostriatal auditory and vocal nuclei of parrots $\rightarrow$ Nidopallial auditory and vocal nuclei of parrots. Several nuclei have been identified in parrots that are devoted to vocal control, including the oval nucleus of the anterior neostriatum (NAo), the medial division of the oval nucleus of the anterior neostriatum (NAom), and the central nucleus of the lateral neostriatum (NLc; Striedter, 1994; Durand et al., 1997; Jarvis and Mello, 2000). With the renaming of the neostriatum, the name for each of these is altered by replacing neostriatum with nidopallium, and the established abbreviations remain the same, but with full capitalization.

\section{Rationale for individual changes: the archistriatum}

General comments on the archistriatum. It has been suggested that the archistriatum of the telencephalon in birds is at least partly comparable to the mammalian amygdala (Edinger et al., 1903; Edinger, 1908; AriënsKappers, 1922; Ariëns-Kappers et al., 1936; Zeier and Karten, 1971; Bruce and Neary, 1995; Puelles et al., 2000), a structure that itself possesses both pallial and subpallial parts (Swanson and Petrovich, 1998; Puelles et al., 2000). Based on neurochemical and developmental data, it seemed overwhelmingly clear to the Forum that all parts of the archistriatum (i.e., the regions with the word archistriatum in their name) as defined in Karten and Hodos (1967) and in Kuenzel and Masson (1988) are pallial (Puelles et al., 2000; Wada et al., 2001, Reiner et al., 2002; Sun et al., 2003). The Forum further concluded that the taenia (also called the nucleus taeniae) has typically been regarded as a part of the archistriatal complex, although this was not reflected in its name (Ariëns-Kappers et al., 1936; Zeier and Karten, 1971; Thompson et al., 1998; Chen et al., 1999; Absil et al., 2002) and that much or all of the taenia is subpallial (Foidart et al., 1999; Cobos et al., 2001b; Absil et al., 2002).

The Forum also concluded that hodological, developmental, neurochemical, and behavioral evidence supported the amygdaloid nature of the taenia and posterior archistriatum (Zeier and Karten, 1971; Veenman et al., 1995b; Lanuza et al., 2000; Puelles et al., 2000; Absil et al., 2002; Roberts et al., 2002). By contrast, the anterior, intermediate, and at least parts of the medial archistriatum have largely somatic features, making them unlike the amygdala in mammals (Zeier and Karten, 1971; Veenman et al., 1995b; Davies et al, 1997; Mello et al., 1998b; Reiner et al., 2002; Wada et al., 2001). Although it was acknowledged that perhaps the anterior, intermediate, and medial archistriatum were, nonetheless, homologous to some parts of the mammalian amygdala and that the differences between them and mammalian amygdala were the result of divergent evolution, the Forum acknowledged that this had not been demonstrated. In addition, even if such an evolutionary relationship was proved, the concern was expressed that it would be misleading and inappropriate to attach a name with visceral and limbic functional implications (i.e., the term amygdala) to a field with prominent somatic traits (Wild, 1993; Knudsen and Knudsen, 1996; Margoliash, 1997).

The Forum resolved these conflicting concerns to its satisfaction by accepting only the posterior part of the archistriatum as warranting the designation of amygdala and appending amygdala to the name of the taenia. For the remaining parts of the archistriatum, the Forum decided to replace archistriatum with the term arcopallium, with the prefix "arco-" referring to the arched contour of the upper boundary of the field. This choice does not foreclose the option of replacing "arco-" with "amygdalo-" for specific arcopallial subdivisions if evidence for such homology becomes convincing. The subpallial region inferior to what we now recommend be called the globus pallidus in birds was renamed the subpallial amygdala. Further comments about the name changes for individual parts of this arcopallial-amygdaloid field follow (Table 5, Figs. 5-9).

Nucleus archistriatalis anterior $(A A) \rightarrow$ Arcopallium anterius (AA). Karten and Hodos (1967) and Kuenzel and Masson (1988) both recognize an anterior archistriatum and show it as an anterior continuation of the intermediate archistriatum, thus questioning whether it is a distinct entity. The Forum saw this issue as separate from the simple matter of renaming this region as the anterior arcopallium (Table 5, Figs. 6B, 7E).

Archistriatum, pars dorsalis (Ad) $\rightarrow$ Arcopallium dorsale $(\boldsymbol{A D})$. This region was called the dorsal archistriatum in Karten and Hodos (1967), but in their reformulation of the archistriatum, Zeier and Karten (1971) renamed this region the dorsal part of the intermediate archistriatum. By neurochemistry and connections, it is a distinct region (Wächtler, 1985; Wächtler and Ebinger, 1989; Medina and Reiner, 1994; Reiner et al., 1994; Veenman et al., 1995b; Kröner and Güntürkün, 1999; Sun and Reiner, 2000). The Forum recommended this region be renamed the dorsal arcopallium (Table 5, Figs. 6F, 7C, 8C, $9 \mathrm{~A}, \mathrm{~B})$, without intermediate in the name, for the sake of simplicity and in recognition of its distinctness.

Dorsal part of archistriatum, pars ventralis $(A v) \rightarrow$ Arcopallium intermedium (AI). This region constituted the dorsal part of the ventral archistriatum in Karten and Hodos (1967), but in their reformulation of the archistriatum, Zeier and Karten (1967) renamed this region the intermediate archistriatum. By neurochemistry and connections, it is distinct from what has until now been called the dorsal intermediate archistriatum (Wächtler, 1985; Wächtler and Ebinger, 1989; Reiner et al., 1994; Veenman et al., 1995b; Kröner and Güntürkün, 1999; Sun and Reiner, 2000). The Forum recommended that the intermediate archistriatum be renamed the intermediate arcopallium, with "pars ventralis" not needed due to the deletion of "intermediate" from the name for the dorsal arcopallium (Table 5, Figs. 6F, 7C, 8C, 9A,B,D).

Archistriatum mediale $($ Am $) \rightarrow$ Arcopallium mediale (AM). This region was largely subsumed within the more medial part of the ventral archistriatum in Karten 
TABLE 5. New Terminology for the Archistriatum

\begin{tabular}{|c|c|c|c|c|}
\hline $\begin{array}{l}\text { Structure and Karten-Hodos (or other) term } \\
\text { for structure (abbreviation) }\end{array}$ & $\begin{array}{l}\text { Latin name adopted } \\
\text { by Forum } \\
\text { (abbreviation) }\end{array}$ & $\begin{array}{l}\text { English name } \\
\text { adopted by Forum } \\
\text { (abbreviation) }\end{array}$ & Comments & $\begin{array}{l}\text { Refs. pertinent to the } \\
\text { new name }\end{array}$ \\
\hline \multicolumn{5}{|l|}{$\begin{array}{l}\text { Archistriatum and subdivisions } \rightarrow \text { Arcopallium and } \\
\text { subdivisions }\end{array}$} \\
\hline Archistriatum (A) & Arcopallium (A) & Arcopallium (A) & $\begin{array}{l}\text { Abbreviation retained, } \\
\text { but arcopallium does } \\
\text { not include PoA, SpA, } \\
\text { or TnA }\end{array}$ & \\
\hline Nucleus archistriatalis anterior (AA) & $\begin{array}{l}\text { Arcopallium anterius } \\
\text { (AA) }\end{array}$ & $\begin{array}{l}\text { Anterior arcopallium } \\
\text { (AA) }\end{array}$ & Abbreviation retained & \\
\hline $\begin{array}{l}\text { Archistriatum, pars dorsalis in Karten and } \\
\text { Hodos (Ad), but termed archistriatum } \\
\text { intermedium, pars dorsalis (Aid) in Zeier and } \\
\text { Karten, } 1971\end{array}$ & Arcopallium dorsale $(\mathrm{AD})$ & Dorsal arcopallium $(\mathrm{AD})$ & $\begin{array}{l}\text { Delete intermediate from } \\
\text { name to simplify }\end{array}$ & $\begin{array}{l}\text { Zeier and Karten, } 1971 \\
\text { Wächtler, } 1985 \\
\text { Reiner et al., } 1994\end{array}$ \\
\hline $\begin{array}{l}\text { Upper part of Archistriatum, pars ventralis (Av), } \\
\text { but termed archistriatum intermedium (Ai) in } \\
\text { Zeier and Karten, } 1971\end{array}$ & $\begin{array}{l}\text { Arcopallium intermedium } \\
\text { (AI) }\end{array}$ & $\begin{array}{l}\text { Intermediate arcopallium } \\
\text { (AI) }\end{array}$ & $\begin{array}{l}\text { Limit the word } \\
\text { intermediate to this } \\
\text { subdivision to simplify }\end{array}$ & Zeier and Karten, 1971 \\
\hline $\begin{array}{l}\text { Medial part of Archistriatum, pars ventralis, but } \\
\text { termed archistriatum mediale (Am) in Zeier } \\
\text { and Karten, } 1971\end{array}$ & $\begin{array}{l}\text { Arcopallium mediale } \\
\text { (AM) }\end{array}$ & Medial arcopallium (AM) & $\begin{array}{l}\text { Needs to be determined if } \\
\text { this region can be } \\
\text { subdivided into } \\
\text { separate limbic and } \\
\text { somatic territories }\end{array}$ & $\begin{array}{l}\text { Zeier and Karten, } 1971 \\
\text { Davies et al., } 1997\end{array}$ \\
\hline $\begin{array}{l}\text { Robust nucleus of archistriatum in songbirds } \\
\text { (RA) }\end{array}$ & $\begin{array}{l}\text { Nucleus robustus } \\
\text { arcopallii (RA) }\end{array}$ & $\begin{array}{l}\text { Robust nucleus of } \\
\text { arcopallium (RA) }\end{array}$ & Abbreviation retained & $\begin{array}{l}\text { Nottebohm et al., } 1976 \\
\text { Bottjer et al., } 1989\end{array}$ \\
\hline $\begin{array}{l}\text { Central nucleus of anterior archistriatum in } \\
\text { parrots (Aac) }\end{array}$ & $\begin{array}{l}\text { Nucleus centralis } \\
\text { arcopallii anterioris } \\
\text { (AAC) }\end{array}$ & $\begin{array}{l}\text { Central nucleus of } \\
\text { anterior arcopallium } \\
\text { (AAC) }\end{array}$ & Abbreviation retained & $\begin{array}{l}\text { Brauth and McHale, } 1988 \\
\text { Durand et al., } 1997\end{array}$ \\
\hline \multicolumn{5}{|l|}{$\begin{array}{l}\text { Archistriatum subdivisions } \rightarrow \text { Amygdala } \\
\text { subdivisions }\end{array}$} \\
\hline $\begin{array}{l}\text { Ventral part of Archistriatum, pars ventralis } \\
\text { plus caudal part of Archistriatum in Zeier and } \\
\text { Karten, } 1971 \text { (Ap) }\end{array}$ & $\begin{array}{l}\text { Nucleus posterioris } \\
\text { amygdalopallii ( } \mathrm{PoA})\end{array}$ & $\begin{array}{l}\text { Posterior pallial } \\
\text { amygdala (PoA) }\end{array}$ & $\begin{array}{l}\text { Abbreviations for } \\
\text { amygdaloid nuclei } \\
\text { similar in form to } \\
\text { emphasize shared } \\
\text { amygdaloid nature }\end{array}$ & $\begin{array}{l}\text { Zeier and Karten, } 1971 \\
\text { Berk and Hawkin, } 1985 \\
\text { Davies et al., } 1997 \\
\text { Dubbeldam et al., } 1997 \\
\text { Lanuza et al., 2000 }\end{array}$ \\
\hline Nucleus taeniae $(\mathrm{Tn})$ & $\begin{array}{l}\text { Nucleus taeniae } \\
\text { amygdalae (TnA) }\end{array}$ & $\begin{array}{l}\text { Nucleus taeniae of the } \\
\text { amygdala (TnA) }\end{array}$ & $\begin{array}{l}\text { Add amygdala to name to } \\
\text { emphasize amygdaloid } \\
\text { nature }\end{array}$ & $\begin{array}{l}\text { Cheng et al., } 1999 \\
\text { Cobos et al., 2001a } \\
\text { Absil et al., } 2002\end{array}$ \\
\hline $\begin{array}{l}\text { Region below paleostriatum primitivum posterior } \\
\text { to anterior commissure (Identified as ventral } \\
\text { part of paleostriatum augmentatum, PA) }\end{array}$ & $\begin{array}{l}\text { Area subpallialis } \\
\text { amygdalae (SpA) }\end{array}$ & $\begin{array}{l}\text { Subpallial amygdaloid } \\
\text { area (SpA) }\end{array}$ & $\begin{array}{l}\text { Homologous to at least } \\
\text { sublenticular part of } \\
\text { extended amygdala in } \\
\text { mammals }\end{array}$ & $\begin{array}{l}\text { Wild et al., } 1990 \\
\text { Molnar et al., } 1994 \\
\text { Reiner et al., } 1994 \\
\text { Atoji et al., } 1996\end{array}$ \\
\hline
\end{tabular}

${ }^{1}$ Summary of the nomenclature recommendations of the Forum for the archistriatum, the major subdivisions within it, and some additional telencephalic cell groups related to the archistriatum. Structures are presented largely in a rostral to caudal and superior to inferior order. For each structure considered, the first column of the table shows the original name assigned (typically from Karten and Hodos, 1967) and the original abbreviation, the next column shows the Latin variant and abbreviation of the new (or carried over) term recommended by the Forum, the next shows the English variant and abbreviation of the new (or carried over) recommended term, and the final two columns present any noteworthy comments about the change and key references pertinent to the change.

and Hodos (1967), but in their reformulation of the archistriatum, Zeier and Karten (1971) renamed this region the medial archistriatum; they regarded it as visceral and limbic in its connections and thus amygdaloid in its nature. More recent studies, however, have suggested that at least part of the medial archistriatum may be somatic in its projections (Davies et al., 1997). Thus, it is unresolved whether the structure known as the medial archistriatum contains any subregions that are amygdaloid in their connectivity and neurochemistry, and certainly the boundaries between any putative limbic and somatic parts are unresolved. The Forum recommended, therefore, that a cautious approach be taken in renaming the medial archistriatum. We recommend calling it the medial arcopallium, until such time as its possible amygdaloid subdivisions are more clearly defined (Table 5, Figs. 6C, 7F, 8C, $9 B)$. Note that the abbreviation recommended for the medial arcopallium is the same as that employed in the Karten and Hodos (1967) atlas for the anterior medial hypothalamic nucleus. We thus suggest that the latter nucleus be abbreviated AMH to avoid a conflict.

Specialized regions in the archistriatum intermedium involved with vocalization or audition $\rightarrow$ Specialized regions in the arcopallium intermedium involved with vocalization or audition. Specialized nuclei involved in vocalization or audition have been identified within the archistriatum intermedium of songbirds, parrots, hummingbirds, and pigeons (Jarvis et al., 2000; Wild et al., 1993). These include the robust nucleus of the archistriatum (RA) of male songbirds and females of some songbird species (Figs 7D, 9D; Nottebohm et al., 1976; Bottjer et al., 1989; Wild, 1993; Margoliash, 1997; Nordeen, 1997), the central nucleus of the anterior archistriatum in parrots (Aac; Paton et al., 1981; Striedter, 1994; Durand et al., 1997), the vocal nucleus of the archistriatum (VA) in hummingbirds (Jarvis et al., 2000), and the ventromedial and dorsomedial nuclei of the intermediate archistriatum (Aivm and Aidm) in pigeons (Wild et al., 1993). With the renaming of the archistriatum, the name for each of these is altered by replacing archistriatum with arcopallium, and the abbreviation remains the same, except for full capitalization (Table 5). Note that the archistriatal cup region adjacent to the $\mathrm{RA}$ has been recognized as part of the auditory pathway in songbirds and is equivalent to Aivm/Aidm in the pigeon (Kelley and Nottebohm, 1979; Mello et al., 1998b).

Posterior archistriatum (Ap) $\rightarrow$ Posterior pallial amygdala (PoA). This region was included as part of the ventral archistriatum in Karten and Hodos (1967), but in their reformulation of the archistriatum, Zeier and Karten (1971) renamed this region the posterior archistriatum and regarded it as visceral and limbic in its con- 
A

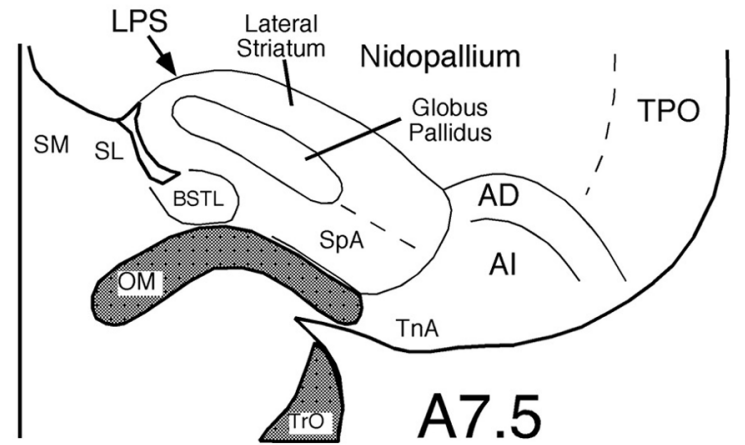

C

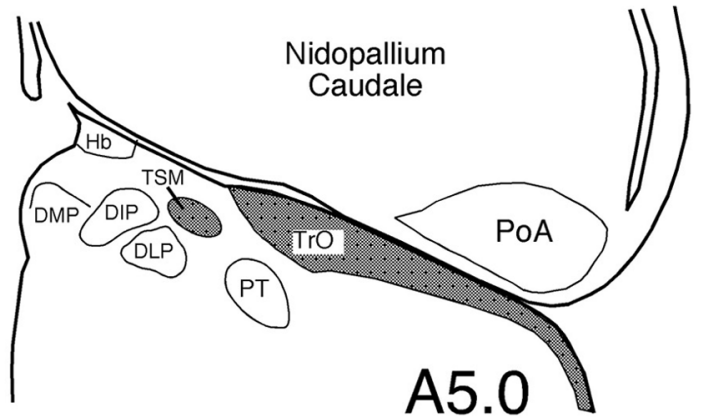

Fig. 9. Line drawings of a rostral to caudal series of transverse sections of pigeon brain illustrating the locations of the major cell groups of the archistriatal region whose names have been revised by the Nomenclature Forum (A-C), and a line drawing of a transverse section of male zebra finch telencephalon showing the location of the RA within the arcopallium (D). The schematics shown in A-C are simplified versions of plates from the stereotaxic atlas of pigeon brain by Karten and Hodos (1967), and numbers to the lower right of each drawing represent the stereotaxic level of that section. Fiber tracts are shaded gray. $\mathrm{AD}$, arcopallium dorsale; $\mathrm{AI}$, arcopallium intermedium; AM, arcopallium mediale; BSTL, lateral part of bed nucleus of stria terminalis; DIP, nucleus dorsointermedius posterior thalami;

nections, and thus amygdaloid in its characteristics. This view has been amply supported in subsequent studies (Berk and Hawkin, 1985; Veenman et al., 1995b; Davies et al., 1997; Dubbeldam et al., 1997; Lanuza et al., 2000; Roberts et al., 2002). For this reason, the Forum recommended that the posterior archistriatum be renamed the posterior pallial amygdala, with pallial in the name to identify it as part of the pallial amygdala in birds (Table 5, Figs. 8C,D, 9C). For this and other amygdaloid nuclei, the Forum assigned three-letter abbreviations to distinguish them from arcopallial nuclei.

Nucleus taeniae (Tn) $\rightarrow$ Nucleus taeniae of the amygdala (TnA). The nucleus taeniae was not extensively discussed in Zeier and Karten (1971) and was thereby seemingly treated as separate from the archistria-
B
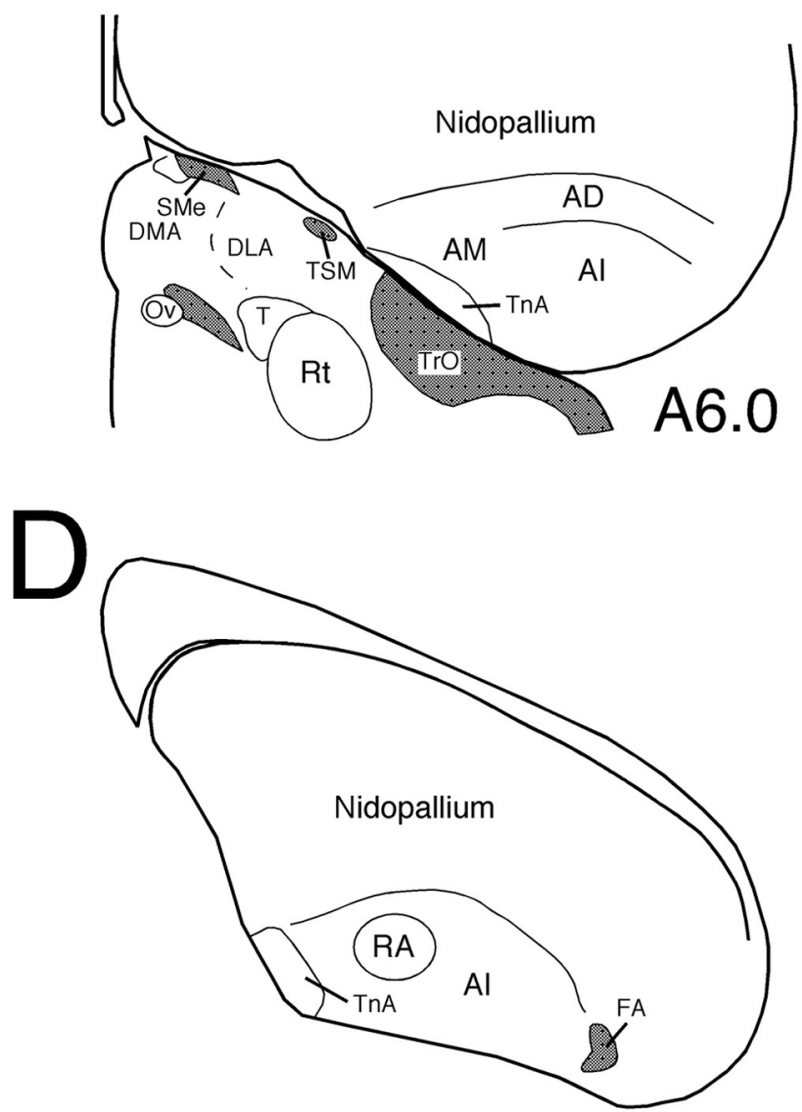

DLA, nucleus dorsolateralis anterior thalami; DLP, nucleus dorsolateralis posterior thalami; DMA, nucleus dorsomedialis anterior thalami; DMP, nucleus dorsomedialis posterior thalami; FA, tractus fronto-arcopallialis; $\mathrm{Hb}$, habenula; LPS, lamina pallio-subpallialis; $\mathrm{OM}$, tractus occipitomesencephalicus; Ov, nucleus ovoidalis; $\mathrm{PoA}$, posterior nucleus of the pallial amygdala; PT, nucleus pretectalis; RA, robust nucleus of the arcopallium; Rt, nucleus rotundus; SL, lateral septal nucleus; SM, medial septal nucleus; SMe, stria medullaris; SpA, subpallial amygdala; T, nucleus triangularis; TnA, taenial amygdala; TPO, area temporo-parieto-occipitalis; TrO, tractus opticus; TSM, tractus septopallio-mesencephalicus.

tal complex. The Forum recognized that any such implication was unintentional and that the nucleus taeniae has been typically regarded as part of the archistriatal complex by investigators of this brain region (Ariëns-Kappers et al., 1936). Thus, the nucleus taeniae is deserving of consideration in the renaming of the parts of the archistriatal complex. Of note, amygdaloid features of the nucleus taeniae have been shown by recent neurochemical, connectional, developmental. and functional studies (Balthazart et al., 1992, 1998; Cheng et al., 1999; Foidart et al., 1999; Lanuza et al., 2000; Cobos et al., 2001b, Absil et al., 2002; Roberts et al., 2002). For this reason, the Forum recommended that the nucleus taeniae be renamed the nucleus taeniae of the amygdala (Table 5, Fig. 6C, 7F, 8C, 9A,B,D). The Forum further acknowledges evidence that 
TABLE 6. Terminology for Other Pallial Structures

\begin{tabular}{|c|c|c|c|c|}
\hline $\begin{array}{l}\text { Structure and Karten-Hodos } \\
\text { (or other) term for structure } \\
\text { (abbreviation) }\end{array}$ & $\begin{array}{l}\text { Latin name adopted by } \\
\text { Forum (abbreviation) }\end{array}$ & $\begin{array}{l}\text { English name } \\
\text { adopted by Forum } \\
\text { (abbreviation) }\end{array}$ & Comments & $\begin{array}{l}\text { Refs. pertinent to the } \\
\text { structure }\end{array}$ \\
\hline \multicolumn{5}{|l|}{ Hippocampal and Corticoid Areas } \\
\hline Area parahippocampalis (APH) & $\begin{array}{l}\text { Area parahippocampalis [no } \\
\text { change] (APH) }\end{array}$ & $\begin{array}{l}\text { Parahippocampal area } \\
\text { [no change] (APH) }\end{array}$ & No change in term needed & $\begin{array}{l}\text { Erichsen et al., } 1991 \\
\text { Krebs et al., } 1991\end{array}$ \\
\hline Hippocampus (Hp) & Hippocampus [no change] $(\mathrm{Hp})$ & $\begin{array}{l}\text { Hippocampus [no change] } \\
\text { (Hp) }\end{array}$ & No change in term needed & $\begin{array}{l}\text { Erichsen et al., } 1991 \\
\text { Krebs et al., } 1991\end{array}$ \\
\hline Cortex piriformis (Cpi) & $\begin{array}{l}\text { Cortex piriformis [no change] } \\
\text { (Cpi) }\end{array}$ & $\begin{array}{l}\text { Piriform cortex [no } \\
\text { change] (Cpi) }\end{array}$ & No change in term needed & Reiner and Karten, 1985 \\
\hline $\begin{array}{l}\text { Area corticoidea dorsolateralis } \\
\text { (CDL) }\end{array}$ & $\begin{array}{l}\text { Area corticoidea dorsolateralis } \\
\text { [no change] (CDL) }\end{array}$ & $\begin{array}{l}\text { Dorsolateral corticoid } \\
\quad \text { area [no change] (CDL) }\end{array}$ & No change in term needed & Redies et al., 2001 \\
\hline $\begin{array}{l}\text { Area temporo-parieto-occipitalis } \\
\text { (TPO) }\end{array}$ & $\begin{array}{l}\text { Area temporo-parieto-occipitalis } \\
\text { [no change] (TPO) }\end{array}$ & $\begin{array}{l}\text { Temporo-parieto-occipital } \\
\text { area [no change] (TPO) }\end{array}$ & $\begin{array}{l}\text { Ill-defined region, but no } \\
\text { change in term needed }\end{array}$ & $\begin{array}{l}\text { Brauth et al., } 1978 \\
\text { Mogensen and Divac, } 1982\end{array}$ \\
\hline
\end{tabular}

${ }^{1}$ Summary of the nomenclature recommendations of the Forum for several additional pallial telencephalic cell groups. In the case of these structures, the Forum recommended the existing name be retained. For each structure considered, the first column of the table shows the original name assigned (typically from Karten and Hodos, 1967) and the original abbreviation, the next column shows the Latin variant and abbreviation of the new (or carried over) term recommended by the Forum, the next shows the English variant and abbreviation of the new (or carried over) recommended term, and the final two columns present any noteworthy comments about the change and key references pertinent to the change.

all or most of the medial part of the nucleus taeniae is subpallial in nature (Absil et al., 2001; Cobos et al., 2001b; Roberts et al., 2002) and therefore perhaps akin to part of the mammalian medial amygdala (a subpallial amygdalar subdivision).

Subpallial region ventral to globus pallidus at level of occipitomesencephalic tract $\rightarrow$ Subpallial amygdala (SpA). A subpallial region ventral to the globus pallidus at the level of the occipitomesencephalic tract possesses the neurochemistry and connectivity of the extended amygdala of mammals, notably its sublenticular part (Berk, 1987; Wild et al., 1990; Molnár et al., 1994; Reiner et al., 1994; Atoji et al., 1996; Lanuza et al., 2000; Wada et al., 2001; Roberts et al., 2002). This region had been depicted as a medial part of the medial archistriatum in Figure 8 of Zeier and Karten (1971) but is shown as a subpallidal part of the striatum (specifically PA) in the Karten and Hodos atlas (1967). Whether birds possess a specific homologue of the mammalian central nucleus of the amygdala, a major subpallial amygdalar region, is yet unresolved (Wild et al., 1990), but the location of the SpA is more comparable to that of the sublenticular extended amygdala than to that of the central amygdaloid nucleus. Nonetheless, the evidence is strong that the aforesaid region below the globus pallidus in birds is both striatal and amygdaloid. For this reason, the Forum recommended that it be recognized as such and for now given the generic name of subpallial amygdala (Table 5, Figs 5F, $6 \mathrm{C}, 7 \mathrm{E}, 9 \mathrm{~A})$. Thus, the currently recognized amygdaloid complex in birds consists of the posterior pallial amygdala, the taenia amygdalae, and the subpallial amygdala.

\section{THE HIPPOCAMPUS, PIRIFORM CORTEX, AND DORSOLATERAL CORTICOID AREA}

There were no compelling reasons to revise the boundaries or nomenclature for the hippocampal complex in birds (Erichsen et al., 1991; Krebs et al., 1991; Szekely, 1999). There was also no evident reason to rename the piriform cortex, temporo-parieto-occipital area (TPO), or dorsolateral corticoid area (CDL; Table 6, Figs. 6C, 8C,D). The anterior-posterior extent of the piriform cortex was, however, recognized to be greater than shown in the various bird brain atlases (Reiner and Karten, 1985), and one recent study has suggested that the extent of the CDL is greater than is shown in standard avian brain atlases (Redies et al., 2001).

\section{TELENCEPHALIC CELL-FREE LAMINAE AND FIBER BUNDLE TERMINOLOGY General considerations}

The Forum recognized that the new nomenclature for cell groups of the telencephalon in birds resulted in the need to change the names of some of the cell-free laminae between major telencephalic regions, and in other cases name changes might be welcome if they helped make the location and nature of the given lamina clearer. The same pertains to fiber tracts. The Forum recommended the following actions (Table 7).

\section{Rationale for individual changes}

Lamina medullaris dorsalis (LMD) $\rightarrow$ Lamina Pallio-subpallialis (LPS). The lamina separating what is now known to be the basal ganglia from what is now known to be the overlying pallium has been called the lamina medullaris dorsalis Karten and Hodos, 1967; Kuenzel and Masson, 1988). Because this term is cryptic in meaning, the Forum recommended a simple and informative new name, the lamina pallio-subpallialis or its English variant, the pallial-subpallial lamina (Table 7, Figs. 6A-D, 8A-C)

Lamina archistriatalis dorsalis (LAD) $\rightarrow$ Lamina arcopallialis dorsalis (LAD). Because the dorsal archistriatum has been renamed the dorsal arcopallium, it was necessary to rename the cell-free border defining the upper edge of what is now called the arcopallium, which separates the arcopallium from what is now called the nidopallium (Zeier and Karten, 1971; Kuenzel and Masson, 1988). The new name, lamina arcopallialis dorsalis, retains the existing abbreviation (Table 7, Fig. 8C,D).

Lamina hyperstriatica $(\mathrm{LH}) \rightarrow$ Lamina mesopallialis (LaM). In changing the name of the hyperstriatum ventrale to the mesopallium, it became inappropriate to refer to the lamina between it and the structure now called the nidopallium as the lamina hyperstriatica. As a new term for this lamina, the Forum recommended the mesopallial lamina or, in Latin, lamina mesopallialis (Table 7, Fig. 8A-C). In this instance, an "a" has been added 
TABLE 7. New Terminology for Telencephalic Fiber Tracts and Intratelencephalic Boundaries

\begin{tabular}{|c|c|c|c|c|}
\hline $\begin{array}{l}\text { Structure and Karten-Hodos } \\
\text { (or other) term for structure } \\
\text { (abbreviation) }\end{array}$ & $\begin{array}{l}\text { Latin name adopted by } \\
\text { Forum (abbreviation) }\end{array}$ & $\begin{array}{l}\text { English name } \\
\text { adopted by Forum } \\
\text { (abbreviation) }\end{array}$ & Comments & $\begin{array}{l}\text { Refs. pertinent to the } \\
\text { new name }\end{array}$ \\
\hline \multicolumn{5}{|l|}{$\begin{array}{l}\text { Intratelencephalic lamina and } \\
\text { boundaries }\end{array}$} \\
\hline $\begin{array}{l}\text { Lamina medullaris dorsalis } \\
\text { (LMD) }\end{array}$ & Lamina pallio-subpallialis (LPS) & $\begin{array}{l}\text { Pallial-subpallial } \\
\text { lamina (PSL) }\end{array}$ & $\begin{array}{l}\text { Change to a clear } \\
\text { descriptive name }\end{array}$ & Puelles et al., 2000 \\
\hline $\begin{array}{l}\text { Lamina archistriatalis dorsalis in } \\
\text { Zeier and Karten, 1971 (LAD) }\end{array}$ & $\begin{array}{l}\text { Lamina arcopallialis dorsalis } \\
\text { (LAD) }\end{array}$ & $\begin{array}{l}\text { Dorsal arcopallial } \\
\text { lamina (LAD) }\end{array}$ & $\begin{array}{l}\text { Abbreviation retained if } \\
\text { Latin used }\end{array}$ & $\begin{array}{l}\text { Zeier and Karten, } 1971 \\
\text { Kuenzel and Masson, } 1988\end{array}$ \\
\hline Lamina hyperstriatica (LH) & Lamina mesopallialis (LaM) & $\begin{array}{l}\text { Mesopallial lamina } \\
\quad(\mathrm{LaM})\end{array}$ & $\begin{array}{l}\text { Change needed since } \\
\text { region above lamina } \\
\text { now the mesopallium }\end{array}$ & \\
\hline Lamina frontalis superior (LFS) & Lamina frontalis superior (LFS) & $\begin{array}{l}\text { Superior frontal } \\
\text { lamina (SFL) }\end{array}$ & No reason to change & \\
\hline Lamina frontalis suprema (LFM) & Lamina frontalis suprema (LFM) & $\begin{array}{l}\text { Supreme frontal } \\
\text { lamina (MFL) }\end{array}$ & No reason to change & \\
\hline \multicolumn{5}{|l|}{ Telencephalic fiber tracts } \\
\hline Tractus thalamostriaticus (TTS) & Tractus thalamopallialis (TTP) & $\begin{array}{l}\text { Thalamopallial tract } \\
\text { (TTP) }\end{array}$ & $\begin{array}{l}\text { Changed because pallial } \\
\text { structures are targets } \\
\text { of tract }\end{array}$ & $\begin{array}{l}\text { Karten and Hodos, } 1970 \\
\text { Karten et al., } 1973 \\
\text { Gamlin and Cohen, } 1986\end{array}$ \\
\hline $\begin{array}{l}\text { Tractus archistriatalis dorsalis } \\
\text { (DA) }\end{array}$ & Tractus dorso-arcopallialis (DA) & $\begin{array}{l}\text { Dorsal arcopallial tract } \\
\text { (DA) }\end{array}$ & Abbreviation retained & \\
\hline $\begin{array}{l}\text { Tractus fronto-archistriatalis } \\
\text { (FA) }\end{array}$ & Tractus fronto-arcopallialis (FA) & $\begin{array}{l}\text { Fronto-arcopallial tract } \\
\text { (FA) }\end{array}$ & Abbreviation retained & \\
\hline $\begin{array}{l}\text { Tractus septomesencephalicus } \\
\text { (TSM) }\end{array}$ & $\begin{array}{l}\text { Tractus septopallio- } \\
\text { mesencephalicus (TSM) }\end{array}$ & $\begin{array}{l}\text { Septopallio- } \\
\text { mesencephalic tract } \\
\text { (TSM) }\end{array}$ & $\begin{array}{l}\text { Not of purely septal } \\
\text { origin; abbreviation } \\
\text { retained with Latin } \\
\text { term }\end{array}$ & $\begin{array}{l}\text { Karten et al., } 1973 \\
\text { Reiner and Karten, } 1983 \\
\text { Wild and Williams, } 2000\end{array}$ \\
\hline $\begin{array}{l}\text { Tractus occipitomesencephalicus } \\
\text { (OM) }\end{array}$ & $\begin{array}{l}\text { Tractus occipito-mesencephalicus } \\
\text { (OM) }\end{array}$ & $\begin{array}{l}\text { Occipito-mesencephalic } \\
\text { tract }(\mathrm{OM})\end{array}$ & No reason to change & Zeier and Karten, 1971 \\
\hline $\begin{array}{l}\text { Tractus occipito-mesencephalicus, } \\
\text { pars hypothalami in Zeier and } \\
\text { Karten, } 1971 \text { (HOM) }\end{array}$ & $\begin{array}{l}\text { Tractus occipito-mesencephalicus, } \\
\text { pars hypothalamica (HOM) }\end{array}$ & $\begin{array}{l}\text { Hypothalamic part of } \\
\text { occipitomesencephalic } \\
\text { tract (HOM) }\end{array}$ & No reason to change & Zeier and Karten, 1971 \\
\hline
\end{tabular}

Summary of the nomenclature recommendations of the Forum for major cell free lamina and fiber bundles of the telencephalon in birds. For each structure considered, the first column of the table shows the original name assigned (typically from Karten and Hodos, 1967) and the original abbreviation, the next column shows the Latin variant and abbreviation of the new (or carried over) term recommended by the Forum, the next shows the English variant and abbreviation of the new (or carried over) recommended term, and the final two columns present any noteworthy comments about the change and key references pertinent to the change.

to the abbreviation to prevent confusion with the medial lemniscus and the nucleus lentiformis mesencephali, which have been abbreviated LM in atlases and studies of avian brains (Karten and Hodos, 1967).

Lamina frontalis superior (LFS) $\rightarrow$ Lamina frontalis superior (LFS). Although it was possible to rename this lamina, which separates the mesopallium from the hyperpallium densocellulare (as we suggest they now be called), the name is not inconsistent with the new terminology and it is entrenched. For this reason and in the absence of consensus as to a new name that is more informative, the Forum recommended retaining this term (Table 7, Fig. 8A,B).

Lamina frontalis suprema (LFM) $\rightarrow$ Lamina frontalis suprema (LFM). Although it was also possible to rename this lamina, which separates the hyperpallium densocellulare from the hyperpallium intercalatum (as we propose they now be called), the name is not inconsistent with the new terminology and it is entrenched. For this reason and in the absence of consensus as to a new name that was more informative, the Forum recommended retaining this term as well (Table 7, Fig. 8A,B).

Tractus thalamostriaticus (TTS) $\rightarrow$ Tractus thalamopallialis (TTP). The fiber-rich zone interposed between the entopallium and the lateral striatum primarily contains axons that had coursed from the nucleus rotundus of the thalamus to the telencephalon via the lateral forebrain bundle (or fasciculus prosencephali lateralis), in their passage to their termination in the structure that we recommend now be called the entopallium (Karten and Hodos, 1970; Nixdorf and Bischof, 1982). This fiber-rich zone has been termed the tractus thalamostriaticus (TTS). This name is inappropriate because the tract, in fact, courses to a pallial and not a striatal target (Karten and Hodos, 1970). The tract does not exclusively terminate within the entopallium, however, because it also appears to contain some fibers arising from the dorsolateral posterior thalamic nucleus (Gamlin and Cohen, 1986) that project to the nidopallial region just medial to the entopallium and some fibers from the principal optic nucleus of the thalamus that project to the Wulst (Karten et al., 1973). Thus, the Forum recommended that the name for this fiber bundle be changed to the tractus thalamopallialis, resulting in some change to the abbreviation for this tract (Table 7, Figs. 6A, 8B).

Tractus archistriatalis dorsalis $(D A) \rightarrow$ Tractus dorso-arcopallialis (DA). This fiber bundle interconnects the dorsal and posterior pallium with the structure now termed the arcopallium. Hence, the name for this tract was changed by the Forum, substituting arcopallialis for archistriatalis and modifying the placement of the adjective in the Latin name slightly, so the existing abbreviation is retained for both the English and Latin forms of the new name (Table 7, Fig. 8C,D).

Tractus fronto-archistriatalis (FA) $\rightarrow$ Tractus fronto-arcopallialis (FA). This fiber bundle interconnects the rostral pallium with the structure now termed the arcopallium. Hence, the name for this tract was changed by the Forum, substituting arcopallialis for archistriatalis, with the existing abbreviation thereby retained (Table 7, Figs. 6A,B, 8B, 9D).

Tractus septomesencephalicus (TSM) $\rightarrow$ Tractus septopallio-mesencephalicus (TSM). Pathway tracing studies have shown that the fiber tract called the TSM in actuality conveys axons from cells in the Wulst and hippocampus to brainstem sites, via axons that traverse the 
septum (Karten et al., 1973; Krayniak and Siegel, 1978a,b; Reiner and Karten, 1983; Wild and Williams, 2000). The Forum also observed that the "-mesencephalicus" part of the name may be somewhat misleading if taken literally, because the Wulst (primarily the HA) via the TSM also gives rise to projections to diencephalic sites and sites posterior to midbrain, including the upper spinal cord in at least some species (Karten et al., 1973; Reiner and Karten, 1983; Wild and Williams, 2000). Nonetheless, for continuity with the previous literature, the Forum concluded that it would be appropriate to rename the tractus septomesencephalicus as the tractus septopallio-mesencephalicus, with no change in abbreviation, to reflect its origin in the pallium (Table 7, Figs. 6B, 9B,C). Note that the portion of the TSM arising from the primary sensory/motor field within the Wulst that courses to upper spinal levels resembles the pyramidal tract of mammals (Medina and Reiner, 2000; Wild and Williams, 2000).

Tractus occipito-mesencephalicus (OM) $\rightarrow$ Tractus occipito-mesencephalicus (OM). No revision was recommended by the Forum for the tractus occipitomesencephalicus, the fiber bundle conveying the descending projection of the arcopallium (Zeier and Karten, 1971), because the name is largely appropriate and it is well entrenched (Table 7, Figs. 6C, 7E, 9A). As in the case of the fiber bundle previously called the tractus septo-mesencephalicus, the Forum noted that the "-mesencephalicus" part of the name might be construed to suggest that the OM projects only to the midbrain, which is not the case (Zeier and Karten, 1971; Wild and Farabaugh, 1996). Nonetheless, the value in retaining the abbreviation for OM was thought to outweigh any slightly misleading connotation in the term OM. In addition, the Forum took the view that the term occipito-mesencephalic tract should not be taken to mean that it interconnects the occipital pole of the telencephalon only with the midbrain, only that the tract extends from telencephalic to midbrain levels.

Tractus occipito-mesencephalicus, pars hypothalami $($ HOM $) \rightarrow$ Tractus occipito-mesencephalicus, pars hypothalami (HOM). No revision was recommended by the Forum for the tractus occipito-mesencephalicus, pars hypothalami, the fiber bundle conveying the descending projection of the arcopallium and amygdala to the hypothalamus (Zeier and Karten, 1971), because the name is largely appropriate and it is well entrenched (Table 7). In addition, the Forum took the view, as noted in Zeier and Karten (1971), that some part of the HOM corresponds to the stria terminalis of mammals. At this time, however, the precise limits of the stria terminalis in birds are uncertain, and the Forum concluded that it was premature to identify a specific fiber tract in birds as the stria terminalis.

\section{FINAL COMMENTS}

Our understanding of avian brain organization and function has advanced enormously in the past 100 years ((Edinger et al., 1903; Edinger, 1908; Ariëns-Kappers, 1922, 1928; Huber and Crosby, 1929; Ariëns-Kappers et al., 1936; Karten, 1969, 1991; Reiner et al., 1998a; Puelles et al., 2000). At the beginning of the 20th century, the intellectual abilities of birds were commonly held in low regard, and they were believed to be limited to an instinctive, inflexible behavioral repertoire (Edinger, 1903, 1908;
Ariëns-Kappers, 1922, 1928; Huber and Crosby, 1929; Arïns-Kappers et al., 1936; Herrick, 1948, 1956). The telencephalon of birds was thought to be devoid of the neural equipment (i.e., cerebral cortex) that allows mammals to adapt their behaviors to their environments, and birds were regarded as instead possessing a telencephalon that consisted of an enormously hypertrophied basal ganglia. Because the basal ganglia were thought to be involved in control of unlearned, instinctual behaviors (Reiner et al., 1984a), the putative basal ganglia hypertrophy in birds appeared to account for what was taken to be their elaborate but stereotyped behavioral repertoire.

It is now evident that birds are not uniformly impoverished in their adaptive learning skills. Songbirds, parrots, and hummingbirds show vocal learning abilities not paralleled by any mammals other than humans and cetaceans (Farbaugh et al., 1994; Durand et al., 1997; Doupe and Kuhl, 1999; Pepperberg, 1999; Hile et al., 2000; Jarvis et al., 2000). Crows, a type of songbird, show the ability to make and use tools (Hunt, 1996, 2000; Weir et al., 2002), and parrots are capable of learning and communicating with simple semantic human language and show cognitive skills evident only in apes and cetaceans among nonhuman species (Pepperberg, 1999, 2002). In parallel with the growing awareness of avian behavioral sophistication has come growth in our understanding of the neural substrates within avian brains allowing such behavior. It has become clear that the telencephalon in birds does not consist of a hypertrophied basal ganglia, but rather possesses a well-developed pallial region that enables birds to perform remarkably complex behaviors. The pallial region in birds, however, does not have a layered organization, as it does in mammals (Karten, 1969, 1991; Reiner et al., 1984a), rather, in birds, the pallium is organized into a largely continuous field of nuclei. Although these nuclei appear to mediate the same functions as the cerebral cortex, they have a cytological appearance more like that of the basal ganglia, explaining the mistake of many earlier comparative neuroanatomists.

The errors in the 20th century terminology for the telencephalon and many brainstem cell groups in birds have perpetuated misconceptions about birds and avian brains and have obscured major conserved features of vertebrate brain evolution. The Avian Brain Nomenclature Forum was the culmination of growing awareness of these errors and their adverse impact on communication among scientists. The Forum sought to devise a new terminology that is free of errors and that promotes accurate understanding of avian brain organization and evolution. We have been scrupulous in our renaming to use only names implying homology that we are certain would not later themselves prove to be in error. We believe that the nomenclature changes we have devised can serve the field well, and we urge all investigators to use this new terminology. Further information and avian brain images depicting this new nomenclature are available on the Avian Brain Nomenclature Exchange website: http://avianbrain.org.

In changing the names of various structures of the forebrain, midbrain, and hindbrain, the Forum does not mean to suggest that these are the only names that would profit from change, only that these are the ones in most obvious need of immediate change. Noteworthy examples of other regions that merit scrutiny for possible revisions are the preoptic area and hypothalamus. Nonetheless, the Forum decided not to consider renaming structures in these re- 

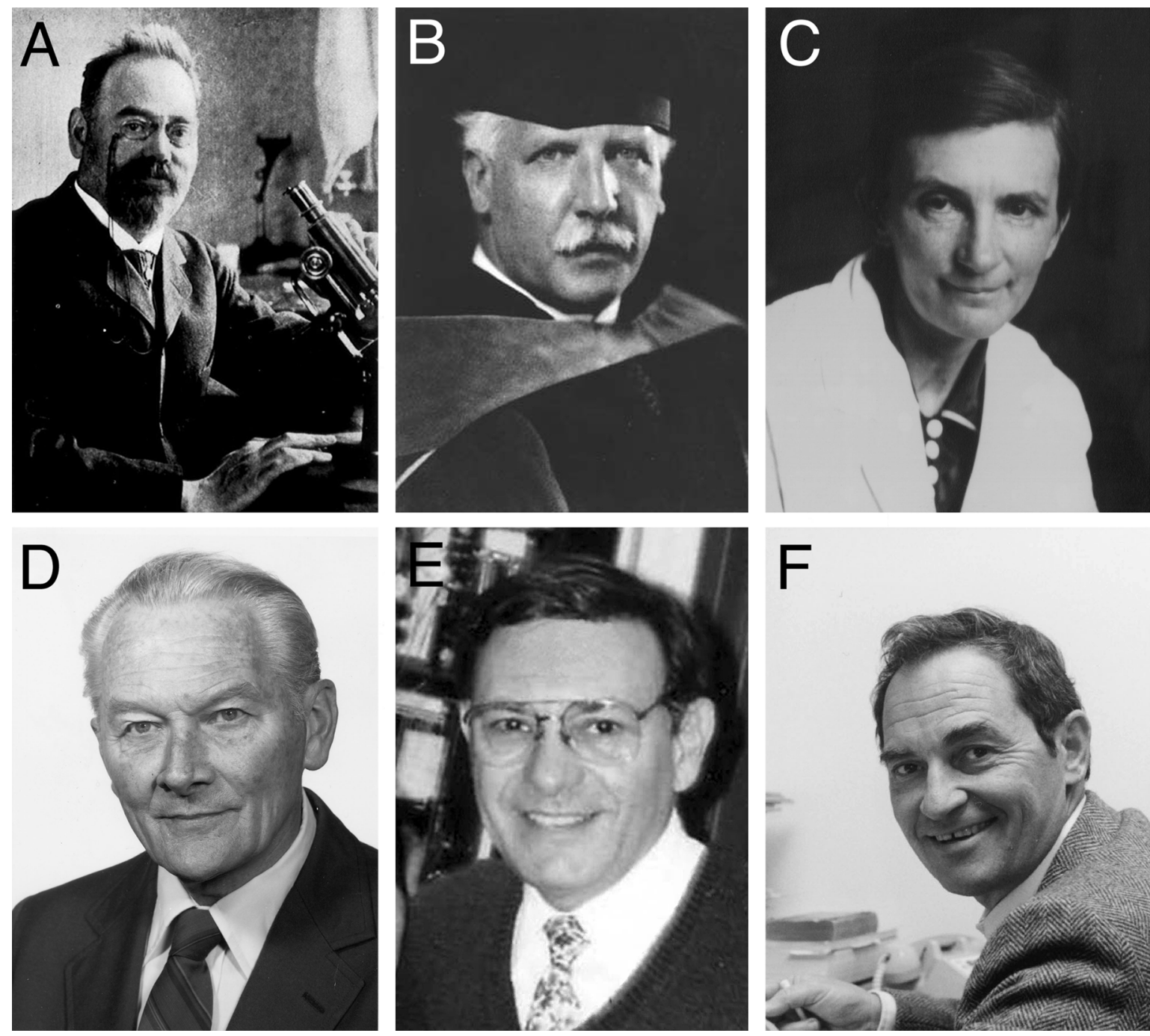

Fig. 10. Photoimages of several of the major contributors to the understanding of the organization of the brain in birds. Ludwig Edinger (A), C.U. Ariëns-Kappers (B), and Elizabeth C. Crosby (C) made many seminal observations during the late 19th and early 20 th centuries on the anatomy of the brain in birds and on the relationship of the brain in birds to those of reptiles and mammals. Although some of their conclusions were in error and led to a need for the terminology revision by the Nomenclature Forum, the work of these investigators provided the foundation upon which later studies were built. D: Walle J. H. Nauta. E,F: William Hodos and Harvey J. Karten. Walle Nauta revolutionized study of not only avian brains but neuroanatomy in

general by his introduction of experimental pathway tracing methods. Moreover, he provided a singular contribution to avian neuroanatomy by his mentoring of Bill Hodos and Harvey Karten during the early parts of their own careers. They, in turn, initiated a renaissance in the study of brain and behavior in birds and provided many of the key insights that have led to the recognition of the need for revisions to avian neuroanatomical nomenclature. Bill Hodos and Harvey Karten truly are the founders of modern avian neurobiology, and we are deeply indebted to them for their leadership, their contributions, and the inspiration they have provided to the field.

gions because detailed descriptions of the cytoarchitecture, neurochemistry, and development of cell groups making up these regions are lacking for birds. Therefore, no recommendations are made at present about these brain areas. However, there are important questions to be resolved for birds, such as the location of the ventromedial hypothalamic nucleus, the subdivisions of the paraventricular nucleus, and the identity of the suprachiasmatic nucleus. Interested readers are directed to the following publications for a discussion of these issues: Berk and Butler (1981), Kuenzel and Van Tienhoven (1982), Berk and Finkelstein (1983), Mikami (1986), Cassone and

Moore (1987), Norgren and Silver (1990), Balthazart et al. (1996), Panzica et al. (1996), and Abraham et al. (2002).

Finally, in revising the terminology, we do not mean either to discredit or to disrespect those neuroscientists before us who proposed and used this terminology, and we disavow any discourtesy to our forerunners. Those who preceded us in the study of avian brains, and developed the terminology that has been used for 100 years, were the leading comparative neuroanatomists of their time. If we today have been able to understand avian brain organization more accurately, it is because we have tools that were not available to them. Moreover, the work they did and the 
ideas they proposed laid an essential foundation, upon which we and others have been able to build in shaping the current view of avian brain structure and function. Thus, in closing this description of the new terminology for avian telencephalic and related brainstem areas, we offer tribute and thanks to Edinger, Rose, Ariëns-Kappers, Crosby, Huber, Kuhlenbeck, Källén, Nauta, Karten, and Hodos for their trailblazing and inspirational work on avian brains and their evolutionary relationship to mammalian brains (Fig. 10).

\section{ACKNOWLEDGMENTS}

We thank the following individuals at Duke University for administrative, technical, and logistical support for the Forum: Deepa Bharanidharan (Jarvis Laboratory Associate in Research), Eunice Chang (Graduate Student), Margaret Couvillon (Graduate Student), Haruhito Horita (Graduate Student), Susan Havrilesky (Neurobiology Department Manager), Michael McElroy (Jarvis Laboratory Research Technician), Dawn Kernagis (Jarvis Laboratory Associate in Research), Lisa Moore (Jarvis Laboratory Manager), Martha Musson (Neurobiology Department Secretary), and the Netfriends computer assistants Ann Sink (Neurobiology Department coordinator), David Stokes (Web designer), and Tony Zimmermann (Jarvis Laboratory Research Analyst). We note the valuable contributions of Dr. Luis Puelles to the discussions on avian brain organization, development, and evolution that preceded the nomenclature meeting, and we thank Drs. Steve Brauth and Todd Roberts for making their data on the parrot telencephalon available to us prior to publication. A number of other researchers, too numerous to list here, made valuable contributions to the discussions in the years leading up to the Forum. Finally, we thank the Archives of the University of Alabama at Birmingham and the MIT Museum for the images of Elizabeth Crosby and Walle Nauta, respectively, in Figure 10. Preparation for the Forum, the Forum itself, and the dissemination of the conclusions of the Forum were supported by grants from NSF and NIH.

\section{DEDICATION}

Finally, we dedicate this paper to Dr. Harvey J. Karten, in many respects the father of modern avian neuroanatomy. He has contributed vastly to the field and been a source of inspiration for many of us. We thank him for this and for his contributions to the nomenclature revision, and we hope our own efforts in this latter regard show him proper recognition and gratitude.

\section{LITERATURE CITED}

Abraham U, Albrecht U, Gwinner E, Brandstatter R. 2002. Spatial and temporal variation of passer Per2 gene expression in two distinct cell groups of the suprachiasmatic hypothalamus in the house sparrow (Passer domesticus). Eur J Neurosci 16:429-436.

Absil P, Baillien M, Ball GF, Panzica GC, Balthazart J. 2001. The control of preoptic aromatase activity by afferent inputs in Japanese quail. Brain Res Brain Res Rev 37:38-58.

Absil P, Braquenier JB, Balthazart J, Ball GF. 2002. Effects of lesions of nucleus taeniae on appetitive and consummatory aspects of male sexual behavior in Japanese quail. Brain Behav Evol 60:13-35.

Anderson KD, Reiner A. 1990. Extensive co-occurrence of substance P and dynorphin in striatal projection neurons: an evolutionarily conserved feature of basal ganglia organization. J Comp Neurol 295:339-369.

Anderson KD, Reiner A. 1991a. Immunohistochemical localization of DARPP-32 in striatal projection neurons and striatal interneurons: implications for the localization of D1-like dopamine receptors on different types of striatal neurons. Brain Res 568:235-243.

Anderson KD, Reiner A. 1991b. Striatonigral projection neurons: a retrograde labeling study of the percentages that contain substance $\mathrm{P}$ or enkephalin in pigeons. J Comp Neurol 303:658-673.

Anderson KD, Karle EJ, Reiner A. 1991. Ultrastructural single- and double-label immunohistochemical studies of substance P-containing terminals and dopaminergic neurons in the substantia nigra in pigeons. J Comp Neurol 309:341-362.

Arends JJA, Zeigler HP. 1986. Anatomical identification of an auditory pathway from a nucleus of the lateral lemniscus to the frontal telencephalon (nucleus basalis) of the pigeon. Brain Res 398:375-381.

Ariëns-Kappers CU. 1922. The ontogenetic development of the corpus striatum in birds and a comparison with mammals and man. Kon Akad v Wetensch te Amsterdam 26:135.

Ariëns-Kappers CU. 1928. The corpus striatum, its phylogenetic and ontogenetic development and functions. Copenhagen: Levin and Munksgaard.

Ariëns-Kappers CU, Huber GC, Crosby E. 1936. The comparative anatomy of the nervous system of vertebrates, including man. New York: Hafner

Aste N, Panzica GC, Viglietti-Panzica C, Harada N, Balthazart J. 1998a. Distribution and effects of testosterone on aromatase mRNA in the quail forebrain: a non-radioactive in situ hybridization study. J Chem Neuroanat 14:103-115.

Aste N, Balthazart J, Absil P, Grossmann R, Mulhbauer E, VigliettiPanzica C, Panzica GC. 1998b. Anatomical and neurochemical definition of the nucleus of the stria terminalis in Japanese quail (Coturnix japonica). J Comp Neurol 396:141-157.

Atoji Y, Shibata N, Yamamoto Y, Suzuki Y. 1996. Distribution of neurotensin-containing neurons in the central nervous system of the pigeon and the chicken. J Comp Neurol 375:187-211.

Atoji Y, Wild JM, Yamamoto Y, Suzuki Y. 2002. Intratelencephalic connections of the hippocampus in pigeons (Columba livia). J Comp Neurol 447:177-199.

Bailhache T, Balthazart J. 1993. The catecholaminergic system of the quail brain: immunocytochemical studies of dopamine beta-hydroxylase and tyrosine hydroxylase. J Comp Neurol 329:230-256.

Ball GF. 1994. Neurochemical specializations associated with vocal learning and production in songbirds and budgerigars. Brain Behav Evol 44:234-246.

Balthazart J, Absil P, Foidart A, Houbart M, Harada N, Ball GF 1996. Distribution of aromatase-immunoreactive cells in the forebrain of zebra finches (Taeniopygia guttata): implications for the neural action of steroids and nuclear definition in the avian hypothalamus. J Neurobiol 31:129-148.

Balthazart J, Foidart A, Houbart M, Prins GS, Ball GF. 1998. Distribution of androgen receptor-immunoreactive cells in the quail forebrain and their relationship with aromatase immunoreactivity. J Neurobiol 35: 323-340.

Balthazart J, Foidart A, Wilson EM, Ball GF. 1992. Immunocytochemical localization of androgen receptors in the male songbird and quail brain. J Comp Neurol 317:407-420.

Baumel JJ. 1979. Nomina anatomica avium: an annotated anatomical dictionary of birds. New York: Academic Press.

Baumel JJ. 1993. Handbook of avian anatomy: nomina anatomica avium. Cambridge, MA: Nuttall Ornithological Club.

Beccari N. 1943. Neurologia comparata anatomo-funzionale dei vertebrati, compresso l'uomo. Firenze: Sansoni Edizioni Scientifiche.

Beckstead RM, Cruz CJ. 1986. Striatal axons to the globus pallidus, entopeduncular nucleus and substantia nigra come mainly from separate cell populations in cat. Neuroscience 19:147-158.

Benowitz LI, Karten HJ. 1976. Organization of the tectofugal visual pathway in the pigeon: a retrograde transport study. J Comp Neurol 167: 503-520.

Berk ML. 1987. Projections of the lateral hypothalamus and bed nucleus of the stria terminalis to the dorsal vagal complex in the pigeon. J Comp Neurol 260:140-156.

Berk ML, Butler AB. 1981. Efferent projections of the medial preoptic nucleus and medial hypothalamus in the pigeon. J Comp Neurol 203 $379-399$ 
Berk ML, Finkelstein JA. 1983. Long descending projections of the hypothalamus in the pigeon, Columba livia. J Comp Neurol 220:127-136.

Berk ML, Hawkin RF. 1985. Ascending projections of the mammillary region in the pigeon: emphasis on telencephalic connections. J Comp Neurol 239:330-340.

Besson MJ, Graybiel AM, Quinn B. 1990. Co-expression of neuropeptides in the cat's striatum: an immunohistochemical study of substance P, dynorphin B and enkephalin. Neuroscience 39:33-58.

Bonke BA, Bonke D, Scheich H. 1979a. Connectivity of the auditory forebrain nuclei in the guinea fowl (Numida meleagris). Cell Tissue Res 200:101-121.

Bonke BA, Scheich H, Langner G. 1979b. Responsiveness of units in the auditory neostriatum of the guinea foul (Numida meleagris) to speciesspecific calls and synthetic stimuli. I. Tonotopy and functional zones of Field L. J. Comp. Physiol. 132:243-255.

Bottjer SW. 1993. The distribution of tyrosine hydroxylase immunoreactivity in the brains of male and female zebra finches. J Neurobiol 24:51-69.

Bottjer SW, Halsema KA, Brown SA, Miesner EA. 1989. Axonal connections of a forebrain nucleus involved with vocal learning in zebra finches. J Comp Neurol 279:312-326.

Brauth SE. 1984. Enkephalin-like immunoreactivity within the telencephalon of the reptile Caiman crocodilus. Neuroscience 11:345-358.

Brauth SE, Kitt CA. 1980. The paleostriatal system of Caiman crocodilus. J Comp Neurol 189:437-465.

Brauth SE, McHale CM. 1988. Auditory pathways in the budgerigar. II. Intratelencephalic pathways. Brain Behav Evol 32:193-207.

Brauth SE, Ferguson JL, Kitt CA. 1978. Prosencephalic pathways related to the paleostriatum of the pigeon (Columba livia). Brain Res 147:205221.

Brauth SE, Reiner A, Kitt CA, Karten HJ. 1983. The substance P-containing striatotegmental path in reptiles: an immunohistochemical study. J Comp Neurol 219:305-327.

Brauth SE, Kitt CA, Reiner A, Quirion R. 1986. Neurotensin binding sites in the forebrain and midbrain of the pigeon. J Comp Neurol 253:358373.

Brauth SE, McHale CM, Brasher CA, Dooling RJ. 1987. Auditory pathways in the budgerigar. I. Thalamo-telencephalic projections. Brain Behav Evol 30:174-199.

Brenowitz EA, Margoliash D, Nordeen KW. 1997. An introduction to birdsong and the avian song system. J Neurobiol 33:495-500.

Brox A, Puelles L, Ferreiro B, Medina L. 2003. Expression of the genes GAD67 and Distal-less-4 in the forebrain of Xenopus laevis confirms a common pattern in tetrapods. J Comp Neurol 461:370-393.

Bruce LL, Neary TJ. 1995. The limbic system of tetrapods: a comparative analysis of cortical and amygdalar populations. Brain Behav Evol 46:224-234.

Buffon GL. 1749. Histoire naturelle, générale et particulière. Paris: Presses Universitaires de France.

Butler AB. 1994. The evolution of the dorsal pallium in the telencephalon of amniotes: cladistic analysis and a new hypothesis. Brain Res Brain Res Rev 19:66-101.

Butler AB, Molnár Z. 2002. Development and evolution of the collopallium in amniotes: a new hypothesis of field homology. Brain Res Bull 57: 475-479.

Butler AB, Molnár Z, Manger PR. 2002. Apparent absence of claustrum in monotremes: implications for forebrain evolution in amniotes. Brain Behav Evol 60:230-240.

Carpenter MB. 1976. Human neuroanatomy. Baltimore: Williams \& Wilkins.

Cassone VM, Moore RY. 1987. Retinohypothalamic projection and suprachiasmatic nucleus of the house sparrow, Passer domesticus. J Comp Neurol 266:171-182

Casto JM, Ball GF. 1994. Characterization and localization of D1 dopamine receptors in the sexually dimorphic vocal control nucleus, area $\mathrm{X}$, and the basal ganglia of European starlings. J Neurobiol 25:767-780.

Cheng M, Chaiken M, Zuo M, Miller H. 1999. Nucleus taenia of the amygdala of birds: anatomical and functional studies in ring doves (Streptopelia risoria) and European starlings (Sturnus vulgaris). Brain Behav Evol 53:243-270.

Cobos I, Puelles L, Martinez S. 2001a. The avian telencephalic subpallium originates inhibitory neurons that invade tangentially the pallium (dorsal ventricular ridge and cortical areas). Dev Biol 239:30-45.

Cobos I, Shimamura K, Rubenstein JL, Martinez S, Puelles L. 2001b. Fate map of the avian anterior forebrain at the four-somite stage, based on the analysis of quail-chick chimeras. Dev Biol 239:46-67.

Cozzi B, Viglietti-Panzica C, Aste N, Panzica GC. 1991. The serotoninergic system in the brain of the Japanese quail. An immunohistochemical study. Cell Tissue Res 263:271-284.

Craigie EH. 1931. The cell masses in the diencephalon of the humming bird. Kon. Akad. v. Wetensch. te Amsterdam, Proc. sect. sc. 34:10381050

Crosby EC, Humphrey T, Lauer EW. 1962. Correlative anatomy of the nervous system. New York: Macmillan.

Csillag A, Stewart MG, Szekely AD, Magloczky Z, Bourne RC, Steele RJ. 1993. Quantitative autoradiographic demonstration of changes in binding to delta opioid, but not mu or kappa receptors, in chick forebrain 30 minutes after passive avoidance training. Brain Res 613:96-105.

Dahlström A, Fuxe K. 1964. Evidence for the existence of monoaminecontaining neurons in the central nervous system. I. Demonstration of monoamines in cell bodies of brainstem neurons. Acta Physiol Scand $62: 1-55$.

Davies DC, Csillag A, Szekely AD, Kabai P. 1997. Efferent connections of the domestic chick archistriatum: a phaseolus lectin anterograde tracing study. J Comp Neurol 389:679-693.

Denisenko-Nehrbass NI, Jarvis E, Scharff C, Nottebohm F, Mello CV. 2000. Site-specific retinoic acid production in the brain of adult songbirds. Neuron 27:359-370.

De Olmos JS, Ingram WR. 1972. The projection field of the stria terminalis in the rat brain. An experimental study. J Comp Neurol 146:303-334.

Doupe AJ, Kuhl PK. 1999. Bird and human speech: common themes and mechanisms. Annu Rev Neurosci 22:567-631.

Dubbeldam JL, Bout RG. 1990. The identification of the motor nuclei innervating the tongue muscles in the mallard (Anas platyrhynchos); an HRP study. Neurosci Lett 119:223-227.

Dubbeldam JL, Visser AM. 1987. The organization of the nucleus basalisneostriatum complex of the mallard (Anas platyrhynchos L.) and its connections with the archistriatum and the paleostriatum complex. Neuroscience 21:487-517.

Dubbeldam JL, den Boer-Visser AM, Bout RG. 1997. Organization and efferent connections of the archistriatum of the mallard, Anas platy rhynchos L.: an anterograde and retrograde tracing study. J Comp Neurol 388:632-657.

Durand SE, Heaton JT, Amateau SK, Brauth SE. 1997. Vocal control pathways through the anterior forebrain of a parrot (Melopsittacus undulatus). J Comp Neurol 377:179-206.

Durstewitz D, Kröner S, Güntürkün O. 1999. The dopaminergic innervation of the avian telencephalon. Prog Neurobiol 59:161-195.

Eden AR, Correia MJ. 1982. An autoradiographic and HRP study of vestibulocollic pathways in the pigeon. J Comp Neurol 211:432-440.

Edinger L. 1908. The relations of comparative anatomy to comparative psychology. J Comp Neurol Psychol 18:437-457.

Edinger L, Wallenberg A, Holmes GM. 1903. Untersuchungen über die vergleichende Anatomie des Gehirns. 3. Das Vorderhirn der Vögel. Abhand Senekenberate Gesellsch Frankfurt Am Main 20:343-426.

Elliot-Smith G. 1901. Notes upon the natural subdivisions of the cerebral hemisphere. J Anat Physiol 35:431-454.

Erichsen JT, Bingman VP, Krebs JR. 1991. The distribution of neuropeptides in the dorsomedial telencephalon of the pigeon (Columba livia): a basis for regional subdivisions. J Comp Neurol 314:478-492.

Faber H, Braun K, Zuschratter W, Scheich H. 1989. System-specific distribution of zinc in the chick brain. A light- and electron-microscopic study using the Timm method. Cell Tissue Res 258:247-257.

Farabaugh SM, Linzenbold A, Dooling RJ. 1994. Vocal plasticity in budgerigars (Lelopsittacus undulatus): evidence for social factors in the learning of contact calls. J Comp Psychol 108:81-92.

Farries MA, Perkel DJ. 2000. Electrophysiological properties of avian basal ganglia neurons recorded in vitro. J. Neurophysiol 84:2502-2513.

Farries MA, Perkel DJ. 2002a. Pallidum-like elements in the avian "striatum" outside of specialized vocal structures project directly to the thalamus. Abstr Soc Neurosci 680.18.

Farries MA, Perkel DJ. 2002b. A telencephalic nucleus essential for song learning contains neurons with physiological characteristics of both striatum and globus pallidus. J Neurosci 22:3776-3787.

Foidart A, Lakaye B, Grisar T, Ball GF, Balthazart J. 1999. Estrogen receptor-beta in quail: cloning, tissue expression and neuroanatomical distribution. J Neurobiol 40:327-342.

Fortune ES, Margoliash D. 1992. Cytoarchitectonic organization and mor- 
phology of cells of the field L complex in male zebra finches (Taenopygia guttata). J Comp Neurol 325:388-404.

Fortune ES, Margoliash D. 1995. Parallel pathways and convergence onto $\mathrm{HVc}$ and adjacent neostriatum of adult zebra finches (Taeniopygia guttata). J Comp Neurol 360:413-441.

Fudge JL, Haber SN. 2001. Bed nucleus of the striaterminalis and extended amygdala inputs to dopamine subpopulations in primates. Neuroscience 104:807-827.

Funke K. 1989a. Somatosensory areas in the telencephalon of the pigeon. I. Response characteristics. Exp Brain Res 76:603-619.

Funke K. 1989b. Somatosensory areas in the telencephalon of the pigeon. II. Spinal pathways and afferent connections. Exp Brain Res 76:620638.

Furuta T, Zhou L, Kaneko T. 2002. Preprodynorphin-, preproenkephalin-, preprotachykinin A- and preprotachykinin B-immunoreactive neurons in the accumbens nucleus and olfactory tubercle: doubleimmunofluorescence analysis. Neuroscience 114:611-627.

Gamlin PD, Cohen DH. 1986. A second ascending visual pathway from the optic tectum to the telencephalon in the pigeon (Columba livia). J Comp Neurol 250:296-310.

Garda AL, Puelles L, Rubenstein JL, Medina L. 2002. Expression patterns of Wnt8b and Wnt7b in the chicken embryonic brain suggest a correlation with forebrain patterning centers and morphogenesis. Neuroscience 113:689-698.

Gerfen CR. 1988. Synaptic organization of the striatum. J Electron Microsc Tech 10:265-281.

Gonzalez A, Smeets WJ. 1994. Catecholamine systems in the CNS of amphibians. In: Smeets WJ, Reiner A, editors. Phylogeny and development of catecholamine systems in the CNS of vertebrates. Cambridge: Cambridge University Press. p 77-102.

Gonzalez A, Lopez JM, Sanchez-Camacho C, Marin O. 2002. Regional expression of the homeobox gene Knx2.1 defines pallidal and interneuronal populations in the basal ganglia of amphibians. Neuroscience 114:567-575.

Graybiel AM. 1990. Neurotransmitters and neuromodulators in the basal ganglia. Trends Neurosci 13:244-253.

Grisham W, Arnold AP. 1994. Distribution of GABA-like immunoreactivity in the song system of the zebra finch. Brain Res 651:115-122.

Guirado S, Davila JC, Real MA, Medina L. 1999. Nucleus accumbens in the lizard Psammodromus algirus: chemoarchitecture and cortical afferent connections. J Comp Neurol 405:15-31.

Güntürkün O. 1991. The functional organization of the avian visual system. In: Andrew RJ, editor. Neural and Behavioral Plasticity. Oxford: Oxford University Press. p 92-105.

Güntürkün O. 1997. Cognitive impairments after lesions of the neostriatum caudolaterale and its thalamic afferent in pigeons: functional similarities to the mammalian prefrontal system? J Hirnforsch 38:133143.

Haefelfinger H. 1957. Beiträge zur Vergleichenden Ontogenese des Vorderhirns bei Vögeln. Basel: Verlag Helbing \& Lichtenhahn.

Heil P, Scheich H. 1985. Quantitative analysis and two-dimensional reconstruction of the tonotopic organization of the auditory field $\mathrm{L}$ in the chick from 2-deoxyglucose data. Exp Brain Res 58:532-543.

Heil P, Scheich H. 1991a. Functional organization of the avian auditory cortex analogue. I. Topographic representation of isointensity bandwidth. Brain Res 539:110-120.

Heil P, Scheich H. 1991b. Functional organization of the avian auditory cortex analogue. II. Topographic distribution of latency. Brain Res. 539:121-125.

Heimer L, Alheid GF, Zaborszky L. 1985. Basal ganglia. In: Paxinos G, editor. The rat nervous system. Orlando: Academic Press. p 37-86

Heimer L, Alheid GF, de Olmos JS, Groenewegen HJ, Haber SN, Harlan RE, Zahm DS. 1997. The accumbens: beyond the core-shell dichotomy. J Neuropsychol Clin Neurosci 9:354-381.

Herrick CJ. 1948. The brain of the tiger salamander. Chicago: The University of Chicago Press.

Herrick CJ. 1956. The evolution of human nature. Austin: University of Texas Press.

Hile AG, Plummer TK, Striedter GF. 2000. Male vocal imitation produces call convergence during pair bonding in budgerigars (Melopsittacus undulatus). Anim Behav 59:1209-1218.

Hillebrand A. 1971. Experimental and descriptive study of the hypoglossal nerve nucleus in the turkey and the goose [in Romanian]. Lucrari Stiintifice, Seria C XIV:45-55
Hillebrand A. 1975. An experimental study concerning the accessory nerve in the chicken and turkey. Anat Anz 137:296-302.

Hodos W. 1993. Visual capabilities of birds. In: Zeigler HP, Bischof H-J, editors. Vision, Brain and Behavior in Birds. Cambridge, MA: MIT Press. p 63-76

Hökfelt T, Martensson R, Bjorklund A, Kleinau S, Goldstein M. 1984. Distributional maps of tyrosine hydroxylase-immunoreactive neurons in the rat brain. In: Bjorklund A, Hokfelt T, editors. Handbook of chemical neuroanatomy. Vol 2. Classical transmitters in the CNS. Amsterdam: Elsevier. p 277-379.

Horn G. 1985. Memory, imprinting and the brain. Oxford: Clarendon Press.

Horster W, Franchini A, Daniel S. 1990. Organization of neck muscle motoneurons in the cervical spinal cord of the pigeon. Neuroreport 1:93-96.

Huber GC, Crosby E. 1929. The nuclei and fiber paths of the avian diencephalon, with consideration of telencephalic and certain mesencephalic centers and connections. J Comp Neurol 48:1-225.

Hunt GR. 1996. Manufacture and use of hook-tools by New Caledonian crows. Nature 379:249-251.

Hunt GR. 2000. Human-like, population-level specialization in the manufacture of pandanus tools by New Caledonian crows Corvus moneduloides. Proc R Soc Lond B Biol Sci 267:403-413.

Husband SA, Shimizu T. 1999. Efferent projections of the ectostriatum in the pigeon (Columba livia). J Comp Neurol 406:329-345.

Iyengar S, Viswanathan SS, Bottjer SW. 1999. Development of topography within song control circuitry of zebra finches during the sensitive period for song learning. J Neurosci 19:6037-57.

Jarvis ED, Mello CV. 2000. Molecular mapping of brain areas involved in parrot vocal communication. J Comp Neurol 419:1-31.

Jarvis ED, Scharff C, Grossman MR, Ramos JA, Nottebohm F. 1998. For whom the bird sings: context-dependent gene expression. Neuron 21 : $775-788$.

Jarvis ED, Ribeiro S, da Silva ML, Ventura D, Vielliard J, Mello CV. 2000 Behaviourally driven gene expression reveals song nuclei in hummingbird brain. Nature 406:628-632.

Jiao Y, Medina L, Veenman CL, Toledo C, Puelles L, Reiner A. 2000. Identification of the anterior nucleus of the ansa lenticularis in birds as the homolog of the mammalian subthalamic nucleus. J Neurosci 20 6998-7010.

Jimenez-Castellanos J, Graybiel AM. 1987. Subdivisions of the dopaminecontaining A8-A9-A10 complex identified by their differential mesostriatal innervation of striosomes and extrastriosomal matrix. Neuroscience 23:223-242.

Johnston JB. 1923. Further contributions to the study of the evolution of the forebrain. J Comp Neurol 35:337-481.

Jurkevich A, Barth SW, Kuenzel WJ, Kohler A, Grossmann R. 1999. Development of sexually dimorphic vasotocinergic system in the bed nucleus of stria terminalis in chickens. J Comp Neurol 408:46-60.

Källén B. 1953. On the nuclear differentiation during embryogeneis in the avian forebrain and some notes on the amniote strio-amygdaloid complex. Avata Anat (Basel) 17:72-84.

Karle EJ, Anderson KD, Medina L, Reiner A. 1996. Light and electron microscopic immunohistochemical study of dopaminergic terminals in the striatal portion of the pigeon basal ganglia using antisera against tyrosine hydroxylase and dopamine. J Comp Neurol 369:109-124.

Karten HJ. 1968. The ascending auditory pathway in the pigeon (Columba livia). II. Telencephalic projections of the nucleus ovoidalis thalami. Brain Res 11:134-153

Karten HJ. 1969. The organization of the avian telencephalon and some speculations on the phylogeny of the amniote telencephalon. In: Noback C, Petras J, editors. Comparative and evolutionary aspects of the vertebrate central nervous system. Ann N Y Acad Sci 167:146-179.

Karten HJ. 1991. Homology and evolutionary origins of the "neocortex." Brain Behav Evol 38:264-272.

Karten HJ, Dubbeldam JL. 1973. The organization and projections of the paleostriatal complex in the pigeon (Columba livia). J Comp Neurol 148:61-90.

Karten HJ, Hodos W. 1967. A stereotaxic atlas of the brain of the pigeon, Columba livia. Baltimore: The Johns Hopkins University Press.

Karten HJ, Hodos W. 1970. Telencephalic projections of the nucleus rotundus in the pigeon (Columba livia). J Comp Neurol 140:35-51.

Karten HJ, Revzin AM. 1966. Rostral projections of the optic tectum and nucleus rotundus in the pigeon. Brain Res 3:264-276. 
Karten H J, Shimizu T. 1989. The origins of neocortex: connections and lamination as distinct events in evolution. J Cogn Neurosci 1:291-301.

Karten HJ, Hodos W, Nauta WJ, Revzin AM. 1973. Neural connections of the "visual wulst" of the avian telencephalon. Experimental studies in the pigeon (Columba livia) and owl (Speotyto cunicularia). J Comp Neurol 150:253-278.

Kelley DB, Nottebohm F. 1979. Projections of a telencephalic auditory nucleus-field L-in the canary. J Comp Neurol 183:455-470.

Kitahama K, Maeda T, Denney RM, Jouvet M. 1994. Monoamine oxidase: distribution in the cat brain studied by enzyme- and immunohistochemistry: recent progress. Prog Neurobiol 42:53-78.

Kitt CA, Brauth SE. 1981. Projections of the paleostriatum upon the midbrain tegmentum in the pigeon. Neuroscience 6:1551-1566.

Kitt CA, Brauth SE. 1986a. Telencephalic projections from midbrain and isthmal cell groups in the pigeon. I. Locus coeruleus and subcoeruleus. J Comp Neurol 247:69-91.

Kitt CA, Brauth SE. 1986b. Telencephalic projections from midbrain and isthmal cell groups in the pigeon. II. The nigral complex. J Comp Neurol 247:92-110.

Knudsen EI, Knudsen PF. 1996. Disruption of auditory spatial working memory by inactivation of the forebrain archistriatum in barn owls. Nature 383:428-431.

Korzeniewska E, Güntürkün O. 1990. Sensory properties and afferents of the N. dorsolateralis posterior thalami of the pigeon. J Comp Neurol 292:457-479.

Krayniak PF, Siegel A. 1978a. Efferent connections of the hippocampus and adjacent regions in the pigeon. Brain Behav Evol 15:372-388.

Krayniak PF, Siegel A. 1978b. Efferent connections of the septal area in the pigeon. Brain Behav Evol 15:389-404.

Krebs JR, Erichsen JT, Bingman VP. 1991. The distribution of neurotransmitters and neurotransmitter-related enzymes in the dorsomedial telencephalon of the pigeon (Columba livia). J Comp Neurol 314:467-477.

Krettek JE, Price JL. 1977. The cortical projections of the mediodorsal nucleus and adjacent thalamic nuclei in the rat. J Comp Neurol 171: 157-191.

Kröner S, Güntürkün O. 1999. Afferent and efferent connections of the caudolateral neostriatum in the pigeon (Columba livia): a retro- and anterograde pathway tracing study. J Comp Neurol 407:228-260.

Kuenzel WJ, Masson M. 1988. A stereotaxic atlas of the brian of the chick (Gallus domesticus). Baltimore: The Johns Hopkins University Press.

Kuenzel WJ, Van Tienhoven A. 1982. Nomenclature and location of avian hypothalamic nuclei and associated circumventricular organs. J Comp Neurol 206:293-313.

Kuhlenbeck H. 1937. The onotogenetic development of diancephalic centers in the bird's brain and comparison with the reptilian and mammalian diencephalon. J Comp Neurol 66:23-75.

Kuhlenbeck H. 1938. The ontogenetic development and phylogenetic significance of the cortex telencephali in the chick. J Comp Neurol 69: $273-301$.

Kuhlenbeck H. 1939. The development and structure of the pretectal cell masses in the chick. J Comp Neurol 71:361-387.

Lanuza E, Davies DC, Landete JM, Novejarque A, Martinez-Garcia F. 2000. Distribution of CGRP-like immunoreactivity in the chick and quail brain. J Comp Neurol 421:515-532.

Lee T, Kaneko T, Taki K, Mizuno N. 1997. Preprodynorphin, preproenkephalin-, and preprotachykinin-expressing neurons in the rat neostriatum: an analysis by immunocytochemistry and retrograde tracing. J Comp Neurol 386:229-244.

Lewis JW, Ryan SM, Butcher LL, Arnold AP. 1981. Evidence for a catecholaminergic projection to area X in the zebra finch. J Comp Neurol 196:347-354

Lovejoy AO. 1936. The Great Chain of Being. Cambridge: Harvard University Press.

Luo M, Perkel DJ. 1999a. A GABAergic, strongly inhibitory projection to a thalamic nucleus in the zebra finch song system. J Neurosci 19:67006711.

Luo M, Perkel DJ. 1999b. Long-range GABAergic projection in a circuit essential for vocal learning. J Comp Neurol 403:68-84.

Margoliash D. 1997. Functional organization of forebrain pathways for song production and perception. J Neurobiol 33:671-693.

Margoliash D, Fortune ES, Sutter ML, Yu AC, Wren-Hardin BD, Dave A. 1994. Distributed representation in the song system of oscines: evolutionary implications and functional consequences. Brain Behav Evol 44:247-264.
Marin O, Rubenstein JL. 2001. A long, remarkable journey: tangential migration in the telencephalon. Nat Rev Neurosci 2:780-790.

Marin O, Smeets WJAJ, Gonzalez A. 1998. Basal ganglia organization in amphibians: chemoarchitecture. J Comp Neurol 392:285-312.

Matochik JA, Reems CN, Wenzel BM. 1991. A brain atlas of the northern fulmar (Fulmarus glacialis) in stereotaxic coordinates. Brain Behav Evol 37:215-244.

Medina L, Reiner A. 1994. Distribution of choline acetyltransferase immunoreactivity in the pigeon brain. J Comp Neurol 342:497-537.

Medina L, Reiner A. 1995. Neurotransmitter organization and connectivity of the basal ganglia in vertebrates: implications for the evolution of basal ganglia. Brain Behav Evol 46:235-258.

Medina L, Reiner A. 1997. The efferent projections of the dorsal and ventral pallidal parts of the pigeon basal ganglia, studied with biotinylated dextran amine. Neuroscience 81:773-802.

Medina L, Reiner A. 2000. Do birds possess homologues of mammalian primary visual, somatosensory and motor cortices? Trends Neurosci 23:1-12.

Medina L, Smeets WJ, Hoogland PV, Puelles L. 1993. Distribution of choline acetyltransferase immunoreactivity in the brain of the lizard Gallotia galloti. J Comp Neurol 331:261-285.

Medina L, Puelles L, Smeets WJ. 1994. Development of catecholamine systems in the brain of the lizard Gallotia galloti. J Comp Neurol 350:41-62.

Medina L, Veenman CL, Reiner A. 1997. Evidence for a possible avian dorsal thalamic region comparable to the mammalian ventral anterior, ventral lateral, and oral ventroposterolateral nuclei. J Comp Neurol 384:86-108.

Medina L, Blanco MJ, Nieto MA, Redies C, Puelles L. 2002. Expression of ephrins, cadherins and nkx2.1 in the chicken subpallium reveals partial interdigitation of striatal and pallidal neurons. Abstr Soc Neurosci 32.4.

Meessen H, Olzsewski J. 1949. A cytoarchitectonic atlas of the rhombencephalon of the rabbit. Basel: S Karger.

Mello CV, Clayton DF. 1994. Song-induced ZENK gene expression in auditory pathways of songbird brain and its relation to the song control system. J Neurosci 14:6652-6666.

Mello CV, Pinaud R, Ribeiro S. 1998a. Noradrenergic system of the zebra finch brain: immunocytochemical study of dopamine-b-hydroxylase. J Comp Neurol 400:207-228.

Mello CV, Vates GE, Okuhata S, Nottebohm F. 1998b. Descending auditory pathways in the adult male zebra finch (Taeniopygia guttata). J Comp Neurol 395:137-160.

Mello CV, Vicario DS, Clayton DF. 1992. Song presentation induces gene expression in the songbird forebrain. Proc Natl Acad Sci U S A 89. $6818-6822$.

Mesulam MM, Mufson EJ, Levey AI, Wainer BH. 1984. Atlas of cholinergic neurons in the forebrain and upper brainstem of the macaque based on monoclonal choline acetyltransferase immunohistochemistry and acetylcholinesterase histochemistry. Neuroscience 12:669-686.

Metzger M, Jiang S, Wang J, Braun K. 1996. Organization of the dopaminergic innervation of forebrain areas relevant to learning: a combined immunohistochemical/retrograde tracing study in the domestic chick. J Comp Neurol 376:1-27.

Mezey S, Csillag A. 2002. Selective striatal connections of midbrain dopaminergic nuclei in the chick (Gallus domesticus). Cell Tissue Res 308: $35-46$.

Miceli D, Reperant J. 1985. Telencephalic afferent projections from the diencephalon and brainstem in the pigeon. A retrograde multiple-label fluorescent study. Exp Biol 44:71-99.

Mikami S-I. 1986. Immunocytochemistry of the avian hypothalamus and adenohypophysis. In: Bourne GH, Jean K, Friedlander M, editors. International review of cytology. San Diego: Academic Press. p 189-248.

Mogensen J, Divac I. 1982. The prefrontal "cortex" in the pigeon. Behavioral evidence. Brain Behav Evol 21:60-66.

Molnár M, Casini G, Davis BM, Bagnoli P, Brecha NC. 1994. Distribution of preproenkephalin mRNA in the chicken and pigeon telencephalon. J Comp Neurol 348:419-432.

Montagnese CM, Geneser FA, Krebs JR. 1993. Histochemical distribution of zinc in the brain of the zebra finch (Taenopygia guttata). Anat Embryol (Berl) 188:173-187.

Moore RY, Card JP. 1984. Noradrenalin-containing neurons. In: Bjorklund A, Hökfelt T, editors. Handbook of chemical neuroanatomy. Volume 2. Classical transmitters in the CNS. Amsterdam: Elsevier. p 123-156.

Müller SC, Scheich H. 1985. Functional organization of the avian auditory field L-a comparative 2DG study. J Comp Physiol 156:1-12. 
Nixdorf BE, Bischof HJ. 1982. Afferent connections of the ectostriatum and visual wulst in the zebra finch (Taeniopygia guttata castanotis Gould)—an HRP study. Brain Res 248:9-17.

Nordeen KW. 1997. Neural correlates of sensitive periods in avian song learning. Ann N Y Acad Sci 807:386-400.

Norgren RB, Silver R. 1990. Distribution of vasoactive intestinal peptide-like and neurophysin-like immunoreactive neurons and acetylcholinesterase staining in the ring dove hypothalamus with emphasis on the question of an avian suprachisamatic nucleus. Cell Tissue Res 259:331-339.

Northcutt RG, Reiner A, Karten HJ. 1988. Immunohistochemical study of the telencephalon of the spiny dogfish, Squalus acanthias. J Comp Neurol 277:250-267.

Nottebohm F. 1987. Birdsong. In: Edelman G, editor. Encyclopedia of Neuroscience. Boston: Birkhauser Boston. p 133-136.

Nottebohm F, Stokes TM, Leonard CM. 1976. Central control of song in the canary, Serinus canarius. J Comp Neurol 165:457-486.

Nottebohm F, Kelley DB, Paton JA. 1982. Connections of vocal control nuclei in the canary telencephalon. J Comp Neurol 207:344-357.

Olszewski J, Baxter D. 1954. Cytoacrchitecture of the human brain stem. Philadelphia: JB Lippincott.

Panzica GC, Viglietti-Panzica C, Balthazart J. 1996. The sexually dimorphic preoptic nucleus of quail: a key brain area mediating steroid receptor action on male sexual behavior. Front Neuroendocrinol 17:51-125.

Patel SN, Rose SP, Stewart MG. 1988. Training induced dendritic spine density changes are specifically related to memory formation processes in the chick, Gallus domesticus. Brain Res 463:168-173.

Paton JA, Manogue KR, Nottebohm F. 1981. Bilateral organization of the vocal control pathway in the budgerigar, Melopsittacus undulatus. J Neurosci 1:1279-1288.

Paxinos G, Watson C. 1998. The rat brain in stereotaxic coordinates. New York: Academic Press.

Pepperberg IM. 1999. The Alex studies. Cambridge, MA: Harvard University Press.

Pepperberg IM. 2002. In search of king Solomon's ring: cognitive and communicative studies of Grey parrots (Psittacus erithacus). Brain Behav Evol 59:54-67.

Popken GJ, Bunney WE Jr, Potkin SG, Jones EG. 2000. Subucleus-specific loss of neurons in medial thalamus of schizophrenics. Proc Natl Acad Sci U S A 97:9276-9280.

Powers AS, Reiner A. 1993. The distribution of cholinergic neurons in the central nervous system of turtles. Brain Behav Evol 41:326-345.

Puelles L, Medina L. 1994. Development of neurons expressing tyrosine hydroxylase and dopamine in the chicken brain: a comparative segmental analysis. In: Smeets WJ, Reiner A, editors. Phylogeny and development of catecholamine systems in the CNS of vertebrates. Cambridge: Cambridge University Press. p 381-404.

Puelles L, Kuwana E, Puelles E, Bulfone A, Shimamura K, Keleher J, Smiga S, Rubenstein JL. 2000. Pallial and subpallial derivatives in the embryonic chick and mouse telencephalon, traced by the expression of the genes Dlx-2, Emx-1, Nkx-2.1, Pax-6, and Tbr-1. J Comp Neurol 424:409-438.

Redies C, Medina L, Puelles L. 2001. Cadherin expression by embryonic divisions and derived gray matter structures in the telencephalon of the chicken. J Comp Neurol 438:253-285.

Rehkämper G, Zilles K, Schleicher A. 1984. A quantitative approach to cytoarchitectonics. IX. The areal pattern of the hyperstriatum ventrale in the domestic pigeon, Columba livia f.d. Anat Embryol (Berl) 169:319-327.

Rehkämper G, Zilles K, Schleicher A. 1985. A quantitative approach to cytoarchitectonics. X. The areal pattern of the neostriatum in the domestic pigeon, Columba livia f.d. A cyto- and myeloarchitectonical study. Anat Embryol (Berl) 171:345-355.

Reiner A. 1986. Is prefrontal cortex found only in mammals? Trends Neurosci 9:298-300.

Reiner A. 1987. The distribution of proenkephalin-derived peptides in the central nervous system of turtles. J Comp Neurol 259:65-91.

Reiner A. 1994. Laminar distribution of the cells of origin of ascending and descending tectofugal pathways in turtles: implications for the evolution of tectal lamination. Brain Behav Evol 43:254-292.

Reiner A. 2000. A hypothesis as to the organization of cerebral cortex in the common reptile ancestor of modern reptiles and mammals. In: Bock GA, Cardew G, editors. Evolutionary developmental biology of the cerebral cortex. London: Novartis. p 83-108; discussion 102-113.

Reiner A, Anderson KD. 1990. The patterns of neurotransmitter and neuropeptide co-occurrence among striatal projection neurons: conclusions based on recent findings. Brain Res Rev 15:251-265.
Reiner A, Carraway RE. 1985. Phylogenetic conservatism in the presence of a neurotensin-related hexapeptide in neurons of globus pallidus. Brain Res. 341:365-371.

Reiner A, Carraway RE. 1987. Immunohistochemical and biochemical studies on Lys8-Asn9-neurotensin8-13 (LANT6)-related peptides in the basal ganglia of pigeons, turtles, and hamsters. J Comp Neurol 257:453-476.

Reiner A, Karten HJ. 1983. The laminar source of efferent projections from the avian Wulst. Brain Res 275:349-354.

Reiner A, Karten HJ. 1985. Comparison of olfactory bulb projections in pigeons and turtles. Brain Behav Evol 27:11-27.

Reiner A, Brauth SE, Kitt CA, Karten HJ. 1980. Basal ganglionic pathways to the tectum: studies in reptiles. J Comp Neurol 193:565-589.

Reiner A, Karten HJ, Brecha NC. 1982. Enkephalin-mediated basal ganglia influences over the optic tectum: immunohistochemistry of the tectum and the lateral spiriform nucleus in pigeon. J Comp Neurol 208:37-53.

Reiner A, Brauth SE, Karten HJ. 1984a. Evolution of the amniote basal ganglia. Trends Neurosci 7:320-325.

Reiner A, Davis BM, Brecha NC, Karten HJ. 1984b. The distribution of enkephalin-like immunoreactivity in the telencephalon of the adult and developing domestic chicken. J Comp Neurol 228:245-262.

Reiner A, Karten HJ, Solina AR. 1983. Substance P: localization within paleostriatal-tegmental pathways in the pigeon. Neuroscience 9:61-85.

Reiner A, Karle EJ, Anderson KD, Medina L. 1994. Catecholaminergic perikarya and fivers in the avian nervous system. In: Smeets WJAJ, Reiner A, editors. Phylogeny and development of catecholaminergic systems in the CNS of vertebrates. Cambridge, England: Cambridge University Press. p 135-181.

Reiner A, Medina L, Veenman CL. 1998a. Structural and functional evolution of the basal ganglia in vertebrates. Brain Res Brain Res Rev 28:235-285.

Reiner A, Perera M, Paullus R, Medina L. 1998b. Immunohistochemical localization of DARPP-32 in striatal projection neurons and striatal interneurons in pigeons. J Chem Neuroanat 16:17-33.

Reiner A, Medina L, Haber SN. 1999. The distribution of dynorphinergic terminals in striatal target regions in comparison to the distribution of substance P-containing and enkephalinergic terminals in monkeys and humans. Neuroscience 88:775-793.

Reiner A, Yamamoto K, Kristal BS. 2002. A multivariate statistical approach to the study of brain homology and development. Abstr Soc Neurosci \#87.15.

Reiner A, Meade CA, Cuthbertson SL, Laverghetta A, Bottjer SW. 2004 An immunohistochemical and pathway tracing study of the striatopallidal organization of Area X in the zebra finch. J Comp Neurol 469: $239-261$.

Riters LV, Erichsen JT, Krebs JR, Bingman VP. 1999. Neurochemical evidence for at least two regional subdivisions within the homing pigeon (Columba livia) caudolateral neostriatum. J Comp Neurol 412:469-487.

Roberts TF, Hall WS, Brauth SE. 2002. Organization of the avian basal forebrain: chemical anatomy in the parrot (Melopsittacus undulatus). J Comp Neurol 454:383-408.

Rose M. 1914. Über die cytoarchitectonische Gliederung des Vorderhirns der Vogel. J Psychol Neurol 21:278-352.

Rose SP, Csillag A. 1985. Passive avoidance training results in lasting changes in deoxyglucose metabolism in left hemisphere regions of chick brain. Behav Neural Biol 44:315-324.

Rubenstein JLR, Martinez S, Shimamura K, Puelles L. 1994. The embryonic vertebrate forebrain: the prosomeric model. Science 266:578-580.

Russchen FT, Jonker AJ. 1988. Efferent connections of the striatum and the nucleus accumbens in the lizard Gekko gecko. J Comp Neurol 276:61-80.

Russchen FT, Smeets WJ, Hoogland PV. 1987. Histochemical identification of pallidal and striatal structures in the lizard Gekko gecko: evidence for compartmentalization. J Comp Neurol 256:329-341.

Schnabel R, Metzger M, Jiang S, Memmings HC, Greengard P, Braun K. 1997. Localization of dopamine D1 receptors and dopaminoceptive neurons in the chick forebrain. J Comp Neurol 38:146-168.

Selemon LD, Goldman-Rakic PS. 1990. Topographic intermingling of striatonigral and striatopallidal neurons in the rhesus monkey. J Comp Neurol 297:359-376.

Shimizu T, Cox K, Karten HJ. 1995. Intratelencephalic projections of the visual wulst in pigeons (Columba livia). J Comp Neurol 359:551-572.

Smeets WJ. 1991. Comparative aspects of the distribution of substance P and dopamine immunoreactivity in the substantia nigra of amniotes. Brain Behav Evol 37:179-188. 
Smeets WJ, Lopez JM, Gonzalez A. 2001. Immunohistochemical localization of DARPP-32 in the brain of the lizard, Gekko gecko: co-occurrence with tyrosine hydroxylase. J Comp Neurol 435:194-210.

Smeets WJAJ. 1994. Catecholamines in the CNS of reptiles: Structure and functional considerations. In: Smeets WJAJ, Reiner A, editors. Phylogeny and development of catecholamine systems in the CNS of vertebrates. Cambridge: Cambridge University Press. p 103-133.

Smeets WJAJ, Reiner A. 1994. Catecholamines in the CNS of vertebrates: Current concepts of evolutions and functional significance. In: Smeets WJAJ, Reiner A, editors. Phylogeny and development of catecholamine systems in the CNS of vertebrates. Cambridge: Cambridge University Press. p 463-481.

Smith H. 1967. Biological similarities and homologies. System Zool 16: 101-102.

Smith-Fernandez A, Pieau C, Reperant J, Boncinelli E, Wassef M. 1998. Expression of the Emx-1 and Dlx-1 homeobox genes define three molecularly distinct domains in the telencephalon of mouse, chick, turtle and frog embryos: implications for the evolution of telencephalic subdivisions in amniotes. Development 125:2099-2111.

Soha J, Shimizu T, Doupe AJ. 1996. Development of the catecholaminergic innervation of the song system of the male zebra finch. J Neurobiol 29:473-489.

Steinbusch HW. 1981. Distribution of serotonin-immunoreactivity in the central nervous system of the rat-cell bodies and terminals. Neuroscience 6:557-618.

Steinbusch HW. 1984. Serotonin-immunoreactive neurons and their projections in the CNS. In: Bjorklund A, Hokfelt T, Kuhar MJ, editors. Handbook of chemical neuroanatomy. Vol 2. Classical transmitters and transmitter receptors in the CNS. Amsterdam: Elsevier. p 68-125.

Stokes TM, Leonard CM, Nottebohm F. 1974. The telencephalon, diencephalon, and mesencephalon of the canary, Serinus canaria, in stereotaxic coordinates. J Comp Neurol 156:337-374.

Striedter GF. 1994. The vocal control pathways in budgerigars differ from those in songbirds. J Comp Neurol 343:35-56.

Striedter GF. 1997. The telencephalon of tetrapods in evolution. Brain Behav Evol 49:179-213.

Sun Z, Reiner A. 2000. Localization of dopamine D1A and D1B receptor mRNAs in the forebrain and midbrain of the domestic chick. J Chem Neuroanat 19:211-224.

Sun Z, Wang HB, Laverghetta A, Yamamoto K, Reiner A. 2003. The distribution and cellular localization of glutamic acid decarboxylase (GAD65) mRNA in the forebrain and midbrain of domestic chick. Abstr Soc Neurosci \#43.13.

Swanson LW, Petrovich GD. 1998. What is the amygdala? Trends Neurosci $21: 323-331$.

Szekely AD. 1999. The avian hippocampal formation: subdivisions and connectivity. Behav Brain Res 98:219-225.

Szekely AD, Boxer MI, Stewart MG, Csillag A. 1994. Connectivity of the lobus parolfactorius of the domestic chicken (Gallus domesticus): an anterograde and retrograde pathway tracing study. J Comp Neurol 348:374-393.

Thompson RR, Goodson JL, Ruscio MG, Adkins-Regan E. 1998. Role of the archistriatal nucleus taeniae in the sexual behavior of male Japanese quail (Coturnix japonica): a comparison of function with the medial nucleus of the amygdala in mammals. Brain Behav Evol 51:215-229.

Vates GE, Broome BM, Mello CV, Nottebohm F. 1996. Auditory pathways of caudal telencephalon and their relation to the song system of adult male zebra finches. J Comp Neurol 366:613-642.

Veenman CL, Gottschaldt KM. 1986. The nucleus basalis-neostriatum complex in the goose (Anser anser L.). Adv Anat Embryol Cell Biol 96:1-85.

Veenman CL, Reiner A. 1994. The distribution of GABA-containing perikarya, fibers, and terminals in the forebrain and midbrain of pigeons, with particular reference to the basal ganglia and its projection targets. J Comp Neurol 339:209-250.

Veenman CL, Karle EJ, Anderson KD, Reiner A. 1995a. Thalamostriatal projection neurons in birds utilize LANT6 and neurotensin: a light and electron microscopic double-labeling study. J Chem Neuroanat 9:1-16.

Veenman CL, Wild JM, Reiner A. 1995b. Organization of the avian "corticostriatal" projection system: a retrograde and anterograde pathway tracing study in pigeons. J Comp Neurol 354:87-126.

Vicario DS, Nottebohm F. 1988. Organization of the zebra finch song control system: I. Representation of syringeal muscles in the hypoglossal nucleus. J Comp Neurol 271:346-354.

Vincent SR, Reiner PB. 1987. The immunohistochemical localization of choline acetyltransferase in the cat brain. Brain Res Bull 18:371-415. von Bartheld CS, Bothwell B. 1992. Development and distribution of nor- adrenergic and cholinergic neurons and their trophic phenotypes in the avian coeruleus complex and midbrain tegmentum. J Comp Neurol $320: 479-500$.

Wächtler K. 1985. Regional distribution of muscarinic acetylcholine receptors in the telencephalon of the pigeon (Columbia livia $\mathrm{f}$. domestica). J Hirnforsch 26:85-89.

Wächtler K, Ebinger P. 1989. The pattern of muscarinic acetylcholine receptor binding in the avian forebrain. J Hirnforsch 30:409-414.

Wada K, Hagiwara M, Jarvis ED. 2001. Brain evolution revealed through glutamate receptor expression profiles. Abstr Soc Neurosci 27:1425.

Watanabe T, Ohmori Y. 1988. Location of motoneurons supplying upper neck muscles in the chicken studied by means of horseradish peroxidase. J Comp Neurol 270:271-278.

Weir AA, Chappell J, Kacelnik A. 2002. Shaping of hooks in New Caledonian crows. Science 297:981.

Wild JM. 1981. Identification and localization of the motor nuclei and sensory projections of the glossopharyngeal, vagus, and hypoglossal nerves of the cockatoo (Cacatua roseicapilla), Cacatuidae. J Comp Neurol 203:351-377.

Wild JM. 1987. Thalamic projections to the paleostriatum and neostriatum in the pigeon (Columba livia). Neuroscience 20:305-327.

Wild JM. 1989. Avian somatosensory system: II. Ascending projections of the dorsal column and external cuneate nuclei in the pigeon. J Comp Neurol 287:1-18.

Wild JM. 1990. Peripheral and central terminations of hypoglossal afferents innervating lingual tactile mechanoreceptor complexes in Fringillidae. J Comp Neurol 298:157-171.

Wild JM. 1992. Direct and indirect "cortico"-rubral and rubro-cerebellar cortical projections in the pigeon. J Comp Neurol 326:623-636.

Wild JM. 1993. Descending projections of the songbird nucleus robustus archistriatalis. J Comp Neurol 338:225-241.

Wild JM. 1997. The avian somatosensory system: the pathway from wing to Wulst in a passerine (Chloris chloris). Brain Res 759:122-134.

Wild JM, Farabaugh SM. 1996. Organization of afferent and efferent projections of the nucleus basalis prosencephali in a passerine, Taeniopygia guttata. J Comp Neurol 365:306-328.

Wild JM, Williams MN. 1999. Rostral wulst of passerine birds: II. Intratelencephalic projections to nuclei associated with the auditory and song systems. J Comp Neurol 413:520-534.

Wild JM, Williams MN. 2000. Rostral wulst in passerine birds. I. Origin, course, and terminations of an avian pyramidal tract. J Comp Neurol 416:429-450.

Wild JM, Zeigler HP. 1980. Central representation and somatotopic organization of the jaw muscles within the facial and trigeminal nuclei of the pigeon (Columba livia). J Comp Neurol 192:175-201.

Wild JM, Arends JJ, Zeigler HP. 1985. Telencephalic connections of the trigeminal system in the pigeon (Columba livia): a trigeminal sensorimotor circuit. J Comp Neurol 234:441-464.

Wild JM, Arends JJ, Zeigler HP. 1990. Projections of the parabrachial nucleus in the pigeon (Columba livia). J Comp Neurol 293:499-523.

Wild JM, Karten HJ, Frost BJ. 1993. Connections of the auditory forebrain in the pigeon (Columba livia). J Comp Neurol 337:32-62.

Wild JM, Reinke H, Farabaugh SM. 1997. A non-thalamic pathway contributes to a whole body map in the brain of the budgerigar. Brain Res 755:137-141.

Wild JM, Kubke MF, Carr CE. 2001. Tonotopic and somatotopic representation in the nucleus basalis of the barn owl, Tyto alba. Brain Behav Evol 57:39-62.

Witkovsky P, Zeigler HP, Silver R. 1973. The nucleus basalis of the pigeon: a single-unit analysis. J Comp Neurol 147:119-128.

Woolf NJ. 1991. Cholinergic systems in mammalian brain and spinal cord. Prog Neurobiol 37:475-524.

Yamada H, Takeuchi Y, Sano Y. 1984. Immunohistochemical studies on the serotonin neuron system in the brain of the chicken (Gallus domesticus). I. The distribution of the neuronal somata. Biogenic Amines 1:83-94.

Youngren OM, Phillips RE. 1978. A stereotaxic atlas of the brain of the three-day-old domestic chick. J Comp Neurol 181:567-599.

Youngren OM, Phillips RE. 1983. Location and distribution of tracheosyringeal motorneuron somata in the fowl. J Comp Neurol 213:86-93.

Zeier H, Karten HJ. 1971. The archistriatum of the pigeon: organization of afferent and efferent connections. Brain Res 31:313-326.

Zijlstra C, Dubbeldam JL. 1994. Organization of the motor innervation of craniocervical muscles in the Mallard, Anas platyrhynchos L. J Hirnforsch $35: 425-440$ 